Florida International University FIU Digital Commons

FIU Electronic Theses and Dissertations

University Graduate School

$12-4-2017$

\title{
Primitivismo y Modernidad en la Literatura Modernista Hispanoamericana
}

Sara Marta Gonzalez

Florida International University, sgonz027@fiu.edu

DOI: $10.25148 /$ etd.FIDC006583

Follow this and additional works at: https://digitalcommons.fiu.edu/etd

Part of the Modern Languages Commons, and the Spanish and Portuguese Language and Literature Commons

\section{Recommended Citation}

Gonzalez, Sara Marta, "Primitivismo y Modernidad en la Literatura Modernista Hispanoamericana" (2017). FIU Electronic Theses and Dissertations. 3675.

https://digitalcommons.fiu.edu/etd/3675

This work is brought to you for free and open access by the University Graduate School at FIU Digital Commons. It has been accepted for inclusion in FIU Electronic Theses and Dissertations by an authorized administrator of FIU Digital Commons. For more information, please contact dcc@fiu.edu. 


\section{FLORIDA INTERNATIONAL UNIVERSITY \\ Miami, Florida}

PRIMITIVISMO Y MODERNIDAD EN LA LITERATURA MODERNISTA HISPANOAMERICANA

A dissertation submitted in partial fullfillment of the requirements for the degree of DOCTOR OF PHILOSOPHY

in

SPANISH

by

Sara M. Gonzalez

2018 
To: John F. Stack, Jr.

School of International and Public Affairs

This dissertation, written by Sara M. Gonzalez, and entitled Primitivismo y modernidad en la literatura modernista Hispanoamericana, having been approved in respect to style and intellectual content, is referred to you for judgment.

We have read this dissertation and recommend that it be approved.

Maida Watson.

Renee Silverman.

Erik Camayd-Freixas, Major Professor.

Date if Defense: December 4, 2017

The dissertation of Sara M. Gonzalez is approved.

Dean John F. Stack, Jr.

School of International and Public Affairs

Andres Gil

Vice President for Research and Economic Development and Dean of the University Graduate School

Florida International University, 2018 
(C) Copyright 2018 by Sara M. Gonzalez

All rights reserved 


\section{ACKNOWLEDGMENTS}

Deseo expresar mi gratitud a mi familia y a los miembros de mi comité por su aliento y apoyo incondicional a lo largo de esta disertación: a la Dra. Rene Silverman por su disposición y valiosos aportes, a la Dra. Maida Watson por sus consejos y ayuda durante todo mi proceso de formación, a la Dra. Sherry

Johnson por sus oportunas observaciones y, en especial, al Dr. Erik Camayd Freixas por su imprescindible guía y minuciosas lecturas.

Igualmente agradezco a Graduate School por concederme el Doctoral Evidence Acquisition (DEA) Fellowship. 


\section{ABSTRACT OF THE DISSERTATION \\ PRIMITIVISMO Y MODERNIDAD EN LA LITERATURA MODERNISTA \\ HISPANOAMERICANA}

by

Sara M. Gonzalez

Florida International University, 2018

Miami, Florida

Professor Erik Camayd-Freixas, Major Professor

This dissertation explores the troubled relationship between Hispanic-American Modernism and modernity through the close study of a representative array of authors (José Martí, Rubén Darío, Enrique Gómez Carrillo, Augusto Dhalmar and Pedro Prado). My analysis departs from the revisionist theories of Angel Rama and Ivan A. Schulman, which changed the traditional views about the movement towards a more complete vision of its role as a literature that is highly subversive.

During the XIX century, America experienced a vigorous cultural awakening unsupported by an incomplete modernization whose more fundamental principles are challenged by the systematic use of primitivism by these authors. I propose that by analyzing how primitivism is used as an essential tool for criticism, a deeper understanding of a highly codified literature and its importance as precursor of the Vanguard may be reached. 


\section{ÍNDICE}

CHAPTER

PAGE

INTRODUCCIÓN: MODERNISMO Y MODERNIZACIÓN, UNA RELACIÓN

CONFLICTIVA

CAPITTULO I EL BALANCE ENTRE MODERNIZACIÓN Y AUTENTICIDAD EN LA

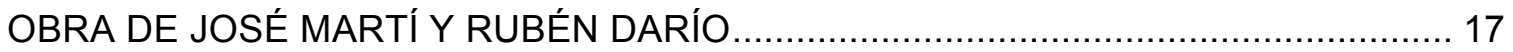

I.I TRADICIONES PREHISPÁNICAS Y UTOPÍA EN EL DISCURSO SOCIAL MARTIANO................ 17

I.2 RUBEN DARÍO: LAS GRUTAS FUNDADORAS DE UN PRIMITIVISMO MODERNISTA ............ 40

CAPITULO II EL JAPÓN EN LA CRÓNICA DE ENRIQUE GÓMEZ CARRILLO, UNA

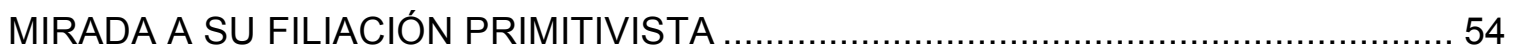

II.1 DE MARSELLA A TOKIO: LA PRIMERA MIRADA DEL OTRO ………......................... 57

II.2 EL EXOTISMO JAPONESISTA DE GÓMEZ CARRILLO O LA INTELECTUALIZACIÓN DE LO PRIMITIVO 68

CAPITULO III DE CHILE A LA INDIA: SENDAS DEL MODERNISMO Y EL PRIMITIVISMO EN AUGUSTO D'HALMAR ……………..................................... 92

III.1 ATISBOS PRIMITIVISTAS EN LA OBRA INICIAL DE AUGUSTO D'HALMAR ..................... 94

III.2 NIRVANA Y LA SOMBRA DEL HUMO EN EL ESPEJO: DOS MIRADAS COMPLEMENTARIAS AL MUNDO ORIENTAL DE AUGUSTO D'HALMAR ...................................................... 105

CAPÍTULO IV EL TRASPLANTE DEFINITIVO DEL PRIMITIVISMO MODERNISTA

A NUESTRAS TIERRAS EN LA OBRA EN PROSA DE PEDRO PRADO ……......... 130

IV.1 MODERNISMO Y PRIMITIVISMO EN LA PROSA DE PEDRO PRADO .......................... 131

IV.2 LA REINA DE RAPA NUI: LA CONCRECIÓN NARRATIVA DE UNA FILIACIÓN PRIMITIVISTA 144

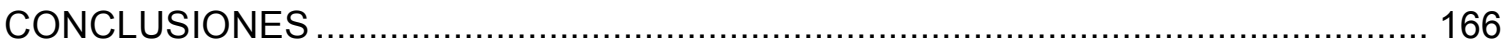

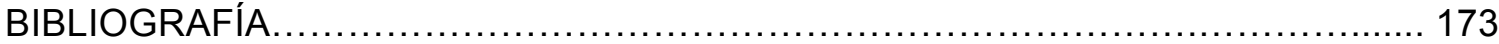

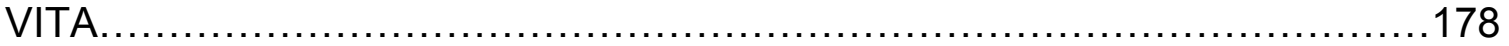


INTRODUCCION: MODERNISMO Y MODERNIZACION, UNA RELACION CONFLICTIVA

A mediados del siglo XIX, la literatura hispanoamericana había alcanzado un grado de madurez notable en varias esferas del sistema literario. Desde el siglo anterior la llegada de la prensa había impulsado exponencialmente el público lector, no solo a partir de la inclusión en sus páginas de discursos propiamente periodísticos, sino también de aquellos cada vez más cercanos a lo ficcional. El número de autores, tertulias y grupos literarios fue incrementándose luego de la Independencia. A la vez que se consolidaba el cultivo de algunos géneros como la poesía y el ensayo, otros, como la novela y el cuento, alcanzaban un estatuto visible y un consumo cada vez mayor. De igual modo, la hibridación genérica que había marcado el surgimiento del discurso literario latinoamericano en las Crónicas de Indias continuaba su marcha con huellas remarcables como Civilización y barbarie. Vida de Juan Facundo Quiroga (1845), de Domingo F. Sarmiento y las Tradiciones peruanas, que Ricardo Palma comenzó a escribir en 1859.

Todo esto vino acompañado de una paulatina secularización de los productos de la industria editorial en el continente y un incremento en las importaciones de textos literarios. A la vez, desde inicios del siglo, las revistas literarias comenzaron a registrar y difundir autores, obras y estéticas, convirtiéndose en redes que propiciaron y reflejaron la densidad de las prácticas culturales. Según Claudio Maíz (82 y ss), durante el último tercio del periodo se 
produjo una transnacionalización de las revistas literarias y de los grupos de autores asociados a ellas. ${ }^{1}$

Sin embargo, a pesar de tales avances en el terreno factual y externo del sistema, en su interior, en el campo ideo-estético, el proceso era, naturalmente, más lento. Los modelos españoles y franceses se mantenían rigiendo el proceso creativo y la independencia política no alcanzaba a permear, aún, los ámbitos culturales. En los comienzos del último cuarto del siglo José Martí se preguntaba:

(...) cuando hay tres siglos que hacer rodar por tierra, que entorpecen aún nuestro andar con sus raíces, y una nación pujante y envidiable que alzar, a ser sustento y pasmo de hombres: será alimento bastante a un pueblo fuerte, digno de su alta cuna y magníficos destinos, la admiración servil a extraños rimadores, la aplicación cómoda y perniciosa de indagaciones de otros mundos, el canto lánguido de los comunes dolorcillos, el cuento hueco en que se fingen pasiones perturbadoras y malsanas, la contemplación peligrosa y exclusiva de las nimias torturas personales, la obra brillante y pasajera de la imaginación estéril y engañosa? (Martí Pérez, El carácter de la Revista Venezolana 209).

Y allí mismo, en el seno de una de las tantas empresas editoriales en las que participó, se respondía: «No: no es esta la obra». Comenzaba una fase significativa en el proceso de maduración de las letras hispanoamericanas.

\footnotetext{
${ }^{1}$ Para ampliar sobre los mecanismos de publicación y distribución literaria en esta época ver: Claudio Maiz. «Las re(d)vistas latinoamericanas y las tramas culturales: Redes de difusión en el romanticismo y en el modernismo.» Cuadernos del CILHA 12.14 (2011): 73-88.
} 
Nuevos modelos, otros discursos y, especialmente, una conciencia poética moderna se instalaban en la praxis cultural del continente.

Algunos textos escritos por José Martí en su paso por Guatemala y Venezuela resultan ejemplares para ilustrar las dos modernidades a las que Matei Calinescu (50-55) hace referencia y, sobre todo, para demostrar que el Modernismo es una respuesta cultural de doble signo: de un lado, es una declaración de independencia cultural, correlato de la alcanzada políticamente por la mayoría de las naciones continentales y de la soñada por las Antillas de habla hispana; del otro, es el producto del enfrentamiento entre el avance de una modernidad incompleta en el terreno socioeconómico y la floración de una modernidad estética vigorosa. A juicio de Calinescu en Europa se había producido «en algún momento de la primera mitad del siglo XIX (...) una irreversible separación entre la modernidad como un momento de la historia de la civilización occidental (...) y la modernidad como un concepto estético» (50), dicha separación tomaba cuerpo en Hispanoamérica con cierto retraso y distintas variables; la principal de ellas es descrita por Beatriz Sarlo en Una modernidad periférica: Buenos Aires (1920-1930) como una modernidad histórica de carácter periférico e impuesta a un continente cuyas áreas poseían diferentes niveles de desarrollo que, a la vez, la anhelaban con desigual denuedo.

De modo que cuando Martí expresa, mientras contribuía a trazar la Constitución guatemalteca, que «se ha sufrido la injerencia de una civilización devastadora, dos palabras que, siendo un antagonismo, constituyen un 
proceso» (98), no hace más que expresar su conciencia de la realidad que Calinescu describe, a la que responde: «con todo el raquitismo de un infante mal herido en la cuna, tenemos toda la fogosidad generosa, inquietud valiente y bravo vuelo de una raza original, fiera y artística» (98).

Un esfuerzo ingente sobre una base endeble, a eso se refiere Renato Ortiz cuando habla de un modernismo sin modernización:

En los países ya industrializados el modernismo plantea la cuestión de la forma artística como una adecuación a la propia transformación de la sociedad (...) Ellos traducían la materialidad de la vida moderna (luz eléctrica, tranvías, sistema ferroviario, automóviles, efervescencia cultural de las metrópolis, etcétera). En América Latina faltaban precisamente esos elementos de modernidad. El modernismo existe pero sin modernización (54).

He aquí lo problemático de la relación entre las dos modernidades en Hispanoamérica. Las reacciones ante semejante «proceso antagónico» fueron también diversas, por lo que la polémica ha acompañado las valoraciones sobre el movimiento. Hasta finales de los años sesenta fue visto por la crítica tradicionalista como un arte homogéneo, exótico y evasionista: "Cuando la crítica, después de la muerte de Darío, identificó el modernismo con Rubén y el arte preciosista, aprendido en los modelos franceses del XIX, estableció las normas de un discurso crítico en términos fundamentalmente monolíticos. $\mathrm{Y}$, en el proceso, pasó por alto las retóricas alternativas de la modernización artística» (Schulman 207). 
Iván Schulman, uno de los nombres imprescindibles en los estudios sobre el tema, reconoce que la comprensión del modernismo siguió dos líneas: una que lo veía como una escuela exclusivamente literaria y fundamentalmente lírica, afrancesada y esteticista; y otra que aprecia en él mucho más que una escuela literaria, la respuesta cultural de una región periférica a la modernización cuyas reacciones abarcan todos los géneros y diversísimos tonos. ${ }^{2}$

Direcciones del Modernismo (1963), de Ricardo Gullón, fue uno de los primeros textos en valorarlo desde esta mirada abarcadora, y al hacerlo releía las opiniones de Juan Ramón Jiménez y Federico de Onís, para quienes el modernismo había que entenderlo como el espíritu de una época de profundas transformaciones. Y lo más asombroso en esta polémica es que se encontraba resuelta desde los inicios: los propios modernistas, al menos la mayoría de ellos, sentían su obra como parte de un «movimiento espiritual muy hondo al que involuntariamente obedecieron y obedecen artistas y escritores de escuelas semejantes» (Díaz Rodríguez 6). De modo que desde el inicio, su revaloración no hizo más que recuperar ese «concepto de un arte acrático y subjetivo producido por la modernización decimonónica de la cultura y la sociedad americanas» (Schulman 207).

Ángel Rama, por su parte, ofreció un punto de vista complementario del fenómeno al abordar sus estrechas relaciones con los efectos de la

\footnotetext{
${ }^{2}$ Las polémicas en torno al modernismo exceden lo abordado en esta introducción. Controversial ha sido la cuestión de sus orígenes, la del carácter precursor o plenamente modernista de la obra de Martí, Nájera, Casal y Silva, la de su exclusividad lírica o su pluralidad genérica... Todo ello no hace más que confirmar que el modernismo fue un momento cultural cuyas consecuencias aún perduran.
} 
capitalización del continente y las transformaciones en el papel del artista dentro de la nueva sociedad que se construía, cuyo utilitarismo poco o nada tenía que ver con la belleza: «la sociedad nueva le está exigiendo al poeta que redefina su función y establezca su nuevo campo de acción, cosas ambas más que difíciles en las tierras hispanoamericanas, donde la endeblez del medio cultural era bien conocida» (Rama, Rubén Darío y el modernismo 46). El burgués y el poeta quedan así enfrentados: el primero no encuentra en cuál lugar de su mundo, eficiente y útil, ubicar al segundo, hasta que finalmente lo relega al sitio de los consolidadores del status quo; el poeta se rebela, provocativo, mordaz, y en ocasiones sube a su torre de marfil para despreciar al primero, quien posee los medios que él necesita para su arte. Muchas obras modernistas reflejan el conflicto tal como lo habían experimentado sus precursores en el simbolismo francés a partir de Baudelaire, cuyo lema era: "épater le bourgeois".

No obstante esta oposición, la palabra de Rama nos advierte que dicha relación entre el artista y la burguesía posee zonas de contacto por la vía del subjetivismo y el individualismo, rasgos de la economía liberal cuyo correlato cultural es el culto a la rareza. Parte de ese amor por lo original es la recurrente autorreferencialidad de las obras (una actitud poco usual hasta entonces), por lo que le extraña a Rama que durante tanto tiempo la crítica se enfocara fundamentalmente en la lírica, cuando el ensayo y la crónica modernistas de carácter metaliterario fueron tan frecuentes y de tan alto vuelo.

Un último aspecto señala el estudio de Rama que no puedo descartar, debido al interés que me suscita la prosa modernista: la relación contradictoria 
del artista con un público creciente y con el único modo de llegar hasta esos lectores potenciales: el mercado. Las siguientes palabras de Rama, ampliamente citadas, explican de un modo inmejorable la situación de estos escritores:

Pero había un modo oblicuo por el cual los poetas habrían de entrar al mercado, hasta devenir parte indispensable de su funcionamiento, sin tener que negarse a sí mismos por entero. Si no ingresan en cuanto poetas, lo harán en cuanto intelectuales. La ley de la oferta y la demanda, que es el instrumento de manejo del mercado, se aplicará también a ellos haciendo que en su mayoría devengan periodistas. En efecto, la generación modernista fue también la brillante generación de los periodistas, a veces llamados a la francesa «chroniqueurs», encargados de una gama intermedia entre la información y el artículo doctrinario o editorial, a saber, notas amenas, comentario de las actualidades, crónicas sociales, crítica de espectáculos teatrales o circenses, eventualmente comentario de libros, perfiles de personajes célebres o artistas, muchas descripciones de viajes de conformidad con la recién descubierta pasión por el vasto mundo (68).

No es de extrañar entonces que pueda leerse en estas obras, y no solo entre líneas, el descontento de los artistas con su medio, los sueños de una realidad diferente, pasada o remota, que sustituyera la actual y la necesidad de un lenguaje otro, nuevo y arcaico a un tiempo, para construir lo propio, ese terreno donde ser verdaderamente libres, donde reinventar la tradición, la escritura. 
Semejante actitud condujo a muchos a calificarlos de evadidos; la comprensión de esa búsqueda del pasado y lo lejano como primitivismo significó un reposicionamiento de los criterios. Erik Camayd-Freixas, en las páginas introductorias a su libro Realismo mágico y primitivismo, afirma: «el primitivismo no es en realidad un concepto unificado, sino una familia de conceptos» (14). Esa pasión del ser humano por mejores tiempos pasados y paraísos lejanos alcanza, según Camayd, dos recurrentes formulaciones hasta el siglo XIX: un primitivismo cronológico y uno de signo cultural, cuyas apariciones se complementan y superponen. Siguiendo a Arthur O. Lovejoy y George Boas (1935) los caracteriza como una filosofía de la historia y una ideología cultural, respectivamente: «El cronológico es la creencia que la edad dorada de la humanidad tuvo lugar en un pasado remoto. El cultural es el descontento del hombre civilizado con la civilización, la certeza que una vida más sencilla y menos sofisticada ofrece mayor plenitud moral» (Camayd-Freixas, 14-15).

Del mismo modo que en el pasado ambas tendencias primitivistas se relacionaron, sobrevivieron en la época moderna bajo formas solapadas, como la creencia del desarrollo cíclico y la búsqueda de lo raro y remoto como refugio. Por supuesto que ambos primitivismos pueden rastrearse en la obra de los autores modernistas, ${ }^{3}$ y el mismo Camayd ve en ella un tránsito hacia un nuevo tipo de primitivismo que la vanguardia entronizaría: el primitivismo estético (17).

\footnotetext{
${ }^{3} \mathrm{E}$ incluso en sus vidas, basten como ejemplos el kimono de Casal y el elitismo de José Presunción Silva.
} 
A finales del siglo XIX comenzó a resquebrajarse el mito de América Latina como una región promisoria y libre, y a crecer la conciencia del carácter periférico de su desarrollo. A la vez, el paradigma cultural europeo mostraba sus primeros signos de agotamiento. En los inicios del modernismo solo José Martí se percató de esos signos y alertó de los peligros, luego del cambio de siglo la mayoría de los autores reaccionaron. El arielismo, aunque de raigambre europea, ya inclinaba la balanza del lado de América y su distinta sensibilidad. Luego de la Revolución Mexicana y de la Primera Guerra Mundial, no se podría confiar más que en la bárbara y propia América.

Pero volvamos al modernismo. Si su exotismo no puede considerarse un primitivismo cronológico ni cultural en toda regla, ello se debe a que ha subordinado la dimensión ética, que consideraba la vida primitiva superior, a la dimensión estética. El primitivismo estético no busca recuperar la edad dorada sino la fuerza expresiva de la misma (Camayd-Freixas, 18), y por expresiva no debemos entender aquí solo lo relativo a la forma literaria, sino a la expresividad de los contenidos de la cultura que es recuperada. Por otra parte, no significaba esto una renuncia a la lucha por un mundo mejor, pues la reactivación del primitivismo solo era posible porque se ganaba conciencia del ser moderno y porque con ese primitivismo se buscaba subvertir los valores de la modernidad. Además, como se verá más adelante, no es poco común encontrar en textos modernistas, sobre todo en la prosa, «un primitivismo más auténtico, a través de la comprensión antropológica de lo americano» (Camayd-Freixas, 11). 
Aunque la imagen de Oriente que aparece en muchos textos modernistas se base en los estereotipos que Occidente ha construido y que el romanticismo y el mismo modernismo ayudaron a reproducir; considero que la mirada de los autores que más adelante estudio no va hacia el exterior de los símbolos sino que busca en ellos significados nuevos que iluminen sus realidades tanto como sus sueños; significados que puedan aportar salidas al conflicto central del Modernismo: la crítica situación del individuo en la Modernidad. Por otro lado, en algunos de estos autores puede leerse la transformación que el Oriente construido va teniendo en su imaginación a medida que entran en contacto directo con esas realidades que antes solo entre-veían. El examen de Oriente se dirige hacia los significados y practicas culturales que, por su antigüedad y su contacto con otras aristas del ser -la relación con la naturaleza, el carácter comunitario, el poder cohesionador de los mitos- sirven de refugio al espantado individuo del cambio de siglo en Latinoamérica. De modo que el examen de Oriente no confirma a Occidente, sino que lo cuestiona

Por la misma razón no podríamos hablar aquí de un exotismo sin mas. El empleo de motivos lejanos -tanto en el tiempo, las culturas antiguas; como en el espacio, el Oriente- responde a la falta de asideros socioculturales que la industrialización, el positivismo y el liberalismo provocan en las naciones del continente y en los intelectuales que la padecen. Las ninfas, odaliscas y princesas medievales son exóticas solo para quienes permanecen en la superficie de la producción modernista y, por lo mismo, tildan de superficiales a sus autores. No ven el hilo que une esos motivos al desencanto de la 
Modernidad, que inunda esos textos, y a la trágica intención, aunque solo sea personal o artística, de ofrecer una solución que reconecte al individuo consigo mismo, con los otros y con su pasado por medio de lo primitivo.

Es en este sentido que puede decirse que el primitivismo estético estaba también presente en el modernismo. Esto explica la presencia de mitos y leyendas americanos en los textos modernistas, sobre todo luego de 1900, como un modo de invocar un tono. Cuando en pleno desarrollo de la vanguardia los latinoamericanos se contagiaron en París del espíritu renovador que obedecía al primitivismo estético, especialmente en la plástica, no reconocieron el primitivismo modernista como un antecedente válido; pero en el fondo, esa renovación ya estaba en ellos.

Desde que Camayd esbozara en 1998 que «el exotismo (incluido el orientalismo modernista) es un importante paso de transición hacia el primitivismo estético de la vanguardia» (17), la mayoría de los estudios de este tema se han enfocado en sus relaciones con la cultura del siglo $x x y$, especialmente, con las artes plásticas. La misma compilación realizada por este autor en 2000, Primitivism and Identity in Latin America: Essays on Art, Literature, and Culture, demuestra esta tendencia. A la vez, los ensayos allí reunidos aportan un enfoque que también me ha sido útil para el análisis: «The present volumen takes a different approach. It seeks to produce a critical view of primitivism in wich the center of analysis is how Latin American subjects employ a western construct to look at themselves and appropriate it for their own purpose» (VIII). Considero que, como parte de esa transición que Camayd 
comentaba en su libro anterior, los autores modernistas fueron ganando conciencia de las posibilidades del primitivismo, más que como instrumental estético, como herramienta de indagación social. Esto entronca también con la tesis de Shulman: el modernismo como discurso alternativo al mercantilismo burgués.

Esa posibilidad nace además del hecho de que América Latina tuvo también una edad dorada —en el sentido mítico del término—: de aztecas, mayas e incas, y una presencia constante del primitivismo. ${ }^{4}$ De la relación de este con cada época y región brotaron significaciones distintas a las que tuvo en Europa, por lo que no puede verse en el primitivismo modernista una simple imitación de la crisis de los otros primitivismo durante el siglo XIX. «As a philosophy of history, as a cultural ideology, or as a radical aesthetics, primitivism has always been a part of the Latin American experience» (Camayd-Freixas, Primitivism and Identity in Latin America: Essays on Art, Literatura, and Culture $\mathrm{X})$.

Partiendo de estos criterios antecedentes, me propongo rastrear la relación modernismo-primitivismo teniendo como hipótesis que los modernistas emplearon sistemáticamente el primitivismo como una herramienta de enfrentamiento crítico a la modernidad. Creo, además, que tal enfrentamiento fue, en primer término, una opción individual, como artistas que no encuentran un lugar en la sociedad moderna, por lo que muchas veces no pueden hallarse

\footnotetext{
${ }^{4}$ Algunos incluso han visto esa época privilegiada en la historia del Continente, ese momento que ya no volverá jamas y en el cual buscar inspiración, en el periodo Colonial.
} 
en ellos soluciones al conflicto; paulatinamente, el descubrimiento de lo autóctono americano fue dando dimensiones mayores a la reacción y perfilando una solución por la vía de lo identitario.

Para la investigación he considerado pertinente dividir el corpus de estudio en dos partes, analizando ese momento inicial en el que el énfasis estuvo en el exotismo, especialmente en su variante orientalista, y la renovación formal; y un segundo momento en el que nuevos autores modernistas se reencontraron con lo autóctono y fortalecieron la relación entre primitivismo y expresión artístico-literaria en América Latina. Este fenómeno no ha sido aún abordado con la sistematicidad que merece. La comprensión cabal de ese proceso sería un pilote más en la reconstrucción del proceso histórico literario, lleno de continuidades y rupturas, que enlaza el siglo XIX con el siglo XX latinoamericano, el romanticismo con la vanguardia.

Debido a la atención que la crítica le ha prestado a los autores centrales del modernismo, y porque ellos ocupan con lo principal de su obra los finales del siglo XIX, en el capítulo inicial realizo un balance de la huella primitivista en la producción de estos autores. El carácter heterogéneo del modernismo, sobre todo en este momento inicial, la originalidad que persiguieron todos sus representantes, agrega dificultad a un balance en el que me centro en la dimensión ética que permea toda la escritura martiana, y que dota a los elementos primitivistas de su obra de un matiz diferente; y en la crucial obra de Rubén Darío, de sinuosa relación con la modernización y lo autóctono. No se trata, no obstante, de un capítulo de autores, sino de una descripción de lo que 
podría llamarse un primer momento de la transición, donde lo formal, exteriorista y exotista centra las relaciones entre primitivismo y modernismo.

Desde los inicios del modernismo va naciendo un camino que aúna las renovaciones formales (muchas de ellas son expresión también de un gusto por lo arcaico, de una recuperación de formas españolas primitivas) con una preocupación por mundos exóticos, pero menos distantes, o por mundos exóticos que son un pretexto para cuestionar de un modo menos sutil la modernidad y su variante hispanoamericana.

A Enrique Gómez Carrillo (1873-1927), Augusto d'Halmar (1882-1950) y Pedro Prado Calvo (1886-1952) están dedicados los restantes capítulos. Aunque se mantuvo alejado de la realidad latinoamericana por sus labores políticas, las crónicas de Gómez Carrillo son un excelente ejemplo del cambio de actitud modernista hacia los mundos exóticos que tradicionalmente había adorado el movimiento. Sus trabajos sobre Asia, especialmente los reunidos en De Marsella a Tokio (1906), El alma japonesa (1907) y El Japón heroico y galante (1912), mezclan el interés antropológico con el cuestionamiento político-social. Sus crónicas sobre la crisis social en los finales de la Rusia zarista y las de la I Guerra Mundial para El Liberal -reeditadas recientemente en España a raíz del centenario del conflicto- contribuyeron a difundir la desconfianza en el modelo de civilización europeo. El ser un testigo central de su época convierte la obra de «El príncipe de las crónicas» en un exponente significativo de la relación entre primitivismo y modernidad sobre la que construye un modelo iconográfico desde el cual subvertir los fundamentos burgueses de la época. 
Otra mirada a estas relaciones se manifiesta en la obra de Augusto d'Halmar, quien encarna la conjunción del naturalismo y el modernismo en las letras chilenas. Como se verá en el tercer capítulo, sus intereses primitivistas pocas veces tocan lo nacional, distanciándose así del criollismo y ofreciendo una variante modernista del fenómeno. No obstante, se aborda en un primer momento la vida literaria de este autor antes de su salida de Chile, más relacionada con la obra de sus coterráneos e influenciada por proyectos como la Colonia Tolstoyana y reuniones a medio camino entre lo literario y el espiritismo, como los machitunes.

Posteriormente mi estudio se centra en los textos Nirvana y La sombra del humo en el espejo como dos miradas complementarias del mundo Oriental. Aunque basados en la misma experiencia real, los textos poseen diferencias tanto en la selección de los acontecimientos narrados como en el acento biográfico más o menos marcado. Por ello nos permiten valorar mejor los significados de la relación entre primitivismo y modernismo a través del espacio real que ha sido surcado: de Chile a la India; pero también desde el espacio imaginario, mucho mayor, que convierte a estas regiones del planeta en zonas irreconciliables en la prosa del autor.

Por último, dedico un acápite a la obra de Pedro Prado, un autor cuya producción más importante está escrita en prosa. Prado abandona el exotismo inicial del modernismo y llega incluso a burlarse de él con la invención del poeta afgano Karez-I-Roshan y sus apócrifos Fragmentos (1921). Me centraré en la prosa, tanto en la de tono poético, que inició en 1912 con La casa abandonada. 
Parábolas y otros ensayos, donde aprecio ese gusto por lo íntimo, esa espiritualización de los conflictos que no es más que una actitud de refugio en la representación de puntos de vista ingenuos y de sujetos marginados; como en la producción novelística, donde La reina de Rapa Nui (1914) adquiere, desde los propósitos que me trazo, un carácter central, por ser un texto en el que Prado reconstruye la sociedad primitiva que, por excelencia, ha sido alter ego del desarrollo civilizador en Chile. ${ }^{5}$ Un estudio contrastivo de la configuración de sus personajes y de la reconstrucción ficticia de la sociedad insular y los efectos de la presencia en ella de sujetos "modernos" muestra otra arista del primitivismo dentro de la prosa modernista.

Al concluir sobre las relaciones entre primitivismo y modernismo, las valoro como un proceso cuyas particularidades se insertan en el más amplio quehacer literario en el continente. Dichas relaciones tomaron cuerpo tanto en la obra de autores centrales del movimiento como en otros menos estudiados a nivel internacional, pero en todos estaba esa actitud cuestionadora del medio e indagadora de las otredades que permite demostrar el carácter transicional del primitivismo modernista, puente entre los primitivismos tradicionales y el primitivismo estético del siglo XX en Hispanoamérica.

\footnotetext{
${ }^{5}$ La novela fue reeditada cinco veces en Chile durante el siglo pasado (Montecino and Foerster), de seguro por esa fascinación que las islas ejercen sobre el imaginario del sujeto continental; pero también por el testimonio que ofrece de los efectos devastadores de la civilización en ese territorio.
} 


\section{CAPITULO I EL BALANCE ENTRE MODERNIZACION Y AUTENTICIDAD EN LA OBRA DE JOSE MARTI Y RUBEN DARIO}

\section{I.I TRAdiciones PREhispánicas y Utopía En El DiscuRso Social MaRtiano}

El movimiento modernista en Hispanoamérica debe a José Martí (1853-1895) mucho más que un conjunto de pautas lingüísticas, técnicas narrativas y modelos estéticos. La críptica representación de motivos primitivistas en el preciosismo retórico del movimiento encuentra raíces profundas en la compleja obra martiana y encuentra fundamento en la afiliación con cierto primitivismo cultural, fruto inmediato del descontento martiano con las transformaciones sociales de la modernidad decimonónica. Sin llegar a ser un crítico reacio del progreso, Martí se proyecta a favor de un modelo cultural alternativo dentro de los parámetros del humanismo y de inspiración tradicionalista.

Ante la euforia del ciudadano contemporáneo por el comercio, el ferrocarril, el crecimiento urbano... en fin, el desarrollo material, la postura martiana se alza crítica hacia un equilibrio entre la aceptación de estos adelantos y la evolución moral de la sociedad. De sus reflexiones en los Estados Unidos podemos inferir la advertencia a los pueblos de América sobre la importancia de recibir tales avances con una conciencia moral equilibrada. Con ello quiere evitar, por medio del ejemplo de Norteamérica, que Hispanoamérica también se pierda en la producción económica desenfrenada, cuando bien conoce que al continente mucho le falta por andar para acoger con carácter 
maduro y templado los beneficios del progreso económico. En Cartas desde Nueva York, por ejemplo, resalta el contraste entre el crecimiento de la ciudad neoyorkina con sus palacios mercantiles, (...) grandes como circos romanos" y la precaria situación de vida y trabajo que sufre el minero sin, "pan en la alacena, ni vestidos para sus hijos, ni más muebles que bancos de madera, ni más asilo que casas hechas de tabla de cajones" (Martí, Carta, Nueva York septiembre 19 de 1885 298); y a continuación añade la siguiente reflexión:

En lo que peca, en lo que yerra, en lo que tropieza, es necesario estudiar a este pueblo para no tropezar como él (...) Gran pueblo es este, y el único donde el hombre puede serlo; pero a fuerza de enorgullecerse de su prosperidad y andar siempre alcanzando para mantener sus apetitos, cae en un pigmeismo moral, en un envenenamiento del juicio, en una culpable adoración de todo éxito (299).

Es precisamente la primacía estadounidense como modelo de una sociedad moderna exitosa, según comienza a erigirse ya en el siglo XIX, un elemento de contraste fundamental en la retórica pro-utopía primitivista martiana. Por encima del bienestar material, Martí destaca el valor de una sociedad socialmente saludable y se apoya repetidamente en las deficiencias del patrón norteamericano.

El efecto que ocasiona la impronta progresista va a afectar de forma universal al intelectual de fin de siglo y conducirá a la reflexión continua, cuya manifestación literaria más significativa es el propio modernismo. El mismo, podría afirmarse, se constituye como la respuesta artística derivada del 
desequilibrio entre el desarrollo social y material en el contexto finisecular y la consecuente alienación que experimenta el artista. La nueva riqueza económica de la emergente clase burguesa y el ritmo acelerado de la vida infringen en el hombre moderno nuevas necesidades, las cuales no se encuentran secundadas por un desarrollo social sólido. Sin desestimar el impacto que el advenimiento de la modernidad, con todas sus exigencias y resultados, tuvo a nivel mundial, este guarda sus particularidades para con Hispanoamérica, donde se produce desde cierta condición marginal, resultado de un desplazamiento acelerado de una condición de coloniaje a un progresismo abrupto, en medio de conflictos étnicos y políticos.

A propósito de la ambigua realidad que experimenta el intelectual en el contexto decimonónico, Matei Calinescu describe en Cinco caras de la modernidad (1987) dos versiones de modernidad simultaneas y contrastantes, una social y otra estética. La primera es definida por el crítico como adepta a:

(...) la doctrina del progreso, la confianza en las posibilidades benefactoras de la ciencia y la tecnología, el interés por el tiempo (un tiempo medible), un tiempo que puede ser comprado y vendido y que, por tanto, posee, como cualquier otra comodidad, un equivalente calculable en dinero, el culto a la razón, y el ideal de libertad definido dentro del entramado de un humanismo abstracto, pero también la orientación hacia un pragmatismo y el culto de la acción y el éxito (51).

Mientras que la segunda es considerada como una actitud opuesta, de rechazo hacia la triunfante civilización establecida por la clase media (51). 
De acuerdo con el pensamiento de Calinescu, habríamos de entender el uso del primitivismo en el marco del modernismo hispanoamericano, y específicamente en la obra martiana, como una herramienta crítica hacia el progresismo decimonónico, precisamente como una forma de expresión de esa segunda modernidad que el crítico describe. El descontento con la civilización, con la forma y el color que el progreso alcanzaba en la sociedad latinoamericana, es eje común del pensamiento modernista y es por ello que podemos considerar a estos autores "críticos de su tiempo". En correspondencia, la literatura modernista, muy a pesar del afamado afrancesamiento y elitismo, es profundamente reflexiva de su entorno sociohistórico, y muestra de ello lo constituye el punto de vista arcaico asimilado en el cultismo lingüístico y el brillo modernista.

La obra de José Martí traza el inicio de este enfrentamiento; es decir, se constituye como una literatura con características opuestas a la filosofía y el modo de vida de su período histórico, oponiéndose a la utopía del progreso y la ciencia por medio del planteamiento de un proyecto alternativo fundamentado en su pensamiento humanista, en el cual integra aspectos de la cultura y el modo de vida prehispánico. Ofrece una perspectiva primitivista a su ideología política, mientras que en el proceso se deriva una crítica a la eficacia y la productividad capitalista. Desde la postura rebelde del artista, el primitivismo modernista marca la independencia que el autor como intelectual reclama con respecto a la ideología burguesa. El programa martiano, en particular, es además utópico por 
la fabricación de un ideal social sustentado en postulados filosóficos y no en un prototipo histórico existente.

A su vez, la perspectiva martiana no está exenta de complejidades, se problematiza más bien en la medida en que constatamos las huellas de un bagaje cultural occidental, condicionado por su condición de criollo. Mientras que en el discurso prevalece un mensaje antiburgués y anticolonialista, la retórica es fundamentalmente burguesa. El punto de vista primitivista incorpora recurrentemente cierta tensión entre el motivo tradicional autóctono americano y una expresión esencialmente occidental, agenciándose con esto una nueva y única posición en el amplio mosaico cultural del nuevo universalismo en el que se circunscribe el quehacer modernista. Se establece como un recurso retórico y estético permeado por el pensamiento político del autor; a la misma vez que ingenia su lugar en el viejo diálogo sobre la identidad cultural americana. El primitivismo en Martí es, ante todo, una forma de espiritualidad comprometida, es esa fuerza que encauza y da coherencia al pensamiento político en aras de un proyecto social.

Considero que un análisis de la evolución de aquellos aspectos más significativos del primitivismo cultural martiano a lo largo de obras representativas facilitará un mejor entendimiento de la madurez y el desarrollo de su programa social al igual que el papel que tiene la retórica y el motivo literario en la configuración de dicho programa. Sustento mi análisis en la opinión de teóricos y en una muestra de textos sin discriminar género literario. Especialmente la crónica exige una mirada atenta dado el auge del periodismo 
en el siglo XIX. Si bien Martí participa de esta modalidad, no se suma a la retórica del consumo, tan en boga entonces. La estética del lujo decimonónico encuentra en él a un representante que opta por una ideología de austeridad y un desborde, eso sí, en el lenguaje. No promueve el entretenimiento como mercancía, según hace la crónica de la época, sino que implícitamente propone sustituirle por el consumo de ideas, por un disfrute de la palabra modernista.

En su tesis doctoral El paradigma ético de la escritura martiana: desbordes de la modernidad, Carlos E. Cenzano recoge la cosmovisión expuesta por José Martí en un grupo de ensayos sobre el tema aborigen y expone una ética martiana desfasada con respecto a la decadente moral de su época, "un viaje invertido hacia el pasado y hacia el interior del sujeto americano arcaico" (Cenzano 192). En oposición al historicismo progresista de su época y al individualismo burgués, el concepto de patria martiano que prioriza el nosotros por encima del yo y que protege al sujeto natural de la orfandad del hombre moderno, le confiere al apóstol, según Cenzano: "una psicología asombrosa, una condición rara entre los hombres" (223). A despecho de la concepción burguesa sobre el progreso, Martí plantea el "crecimiento y mejoramiento del espíritu humano (...) Para él, avance y crecimiento tienen lugar con el concurso de todas las razas y todos los pueblos en armonía con la naturaleza y no de unos pocos en detrimento de la mayoría" (227).

Una de las primeras influencias, y de las más decisivas en iniciar el camino de José Martí por el primitivismo cultural, data de su contacto con el Trascendentalismo norteamericano. Martí se adhiere a la filosofía de Ralph 
Waldo Emerson (1803-1882) como respuesta alternativa al declive de ciertos valores éticos en la sociedad norteamericana, la cual importa los adelantos europeos con una plataforma social deficiente y en desventaja, con un pobre compromiso con la clase trabajadora. Ante el alto costo social del afán progresista, surge Emerson como un profeta que señala el regreso a un modo de vida más simple, la revalorización de la experiencia comunitaria y el reencuentro con la naturaleza... entre otros aspectos que marcan un radicalismo tradicionalista tanto en el pensamiento como en la experiencia vital, hecho este que despierta la admiración del joven Martí en busca de respuestas para la deshumanización de su tiempo.

Ivan A. Schulman, en Símbolo y color en la obra de José Martí (1960), descubre la presencia de Emerson en la obra martiana por medio de un paralelismo recurrente entre las imágenes de la naturaleza y los estados emocionales. Le llama filosofía panteísta. Una sección del texto es dedicada al examen de los personajes en Amistad Funesta (1885), llegando a encontrar una conexión de signo totémico entre ciertos aspectos del carácter de los mismos y rasgos animales representativos, animales exóticos del continente americano (Sculman 424).

Por mi parte, considero que el descubrimiento de una nueva espiritualidad a tono con la escuela norteamericana favorece a José Martí el encauzamiento de su plan político hacia un modelo coherente dentro de los parámetros del Humanismo. Martí, más que un guía espiritual es un líder político, y su postura queda dilucidada cuando aboga por el indio 
norteamericano en su ensayo "Los indios en los Estados Unidos", donde rechaza la asimilación cultural en su totalidad, la cual resultaría en la europeización del sujeto. Podemos afirmar entonces que el Trascendentalismo le facilita una plataforma de reflexión a la misma vez que le introduce a la problemática del indio como grupo étnico, una realidad vigente en gran parte del continente americano, pero ajena para él hasta ese momento.

Del mismo modo en que para Emerson el Trascendentalismo significa un distanciamiento de la influencia europea, un despertar a los valores culturales autóctonos; el primitivismo martiano marca una ruptura con la herencia colonial. Se trata de una perspectiva estética que va a consolidarse en un modelo retórico con características y modos de expresión diferentes a lo largo del corpus textual, pero siempre consciente de la brecha que se agencia con la colonia como autoridad cultural.

Este modelo primitivista se manifiesta fundamentalmente en el tratamiento de las culturas precolombinas junto al lugar del amerindio, en lo que considero un discurso conciliatorio. En el mismo se produce un intento de negociación entre un idealismo utópico, resultado en alguna medida de un remanente romántico, junto a la carencia de una perspectiva íntima por razones fundamentalmente históricas y de circunstancia personal; y la búsqueda de un lugar concreto para el amerindio en su proyecto histórico. Consecuentemente, la representación del indígena a lo largo de la obra martiana se muestra fragmentada y en ocasiones, aparentemente contradictoria. El indio y su cultura tienen varias formas fundamentales: un perfil idealizado, el cual se constituye 
como elemento contundente en el discurso anticolonialista y a la misma vez contribuye a la revalorización socio-cultural; la visión del vencido, cuyo objetivo esencial es la crítica y la denuncia social; y también aproximaciones a una representación realista como empeño de un reclamo de participación en el presente histórico.

El conocimiento que Martí ostenta inicialmente sobre la cultura y la realidad social del indio es vasto y profundo, pero esencialmente libresco. Este hecho conduce a una visión muchas veces paternalista y poco íntima, a saltos entre la idealización y la representación generalizada. No es hasta el exilio que comienza a tener un contacto más directo con las condiciones vitales del indio americano, primero durante su estancia en los Estados Unidos y luego en Guatemala, fuente de inspiración para su única novela: Amistad Funesta.

Esta pieza de carácter local es escenario dramático para el tema indio desde el punto de vista de la ficción, perspectiva poco frecuente en la obra martiana. La voz narrativa claramente se identifica con la postura antipositivista, manifiesta en múltiples comentarios desfavorables sobre el racismo extendido por el continente. Denuncia las condiciones de sojuzgamiento a que se enfrenta el indígena, cuya pobreza es como una mancha según se afirma en una descripción de tono costumbrista sobre el paseo dominical de la época: "Los indios, en verdad, descalzos y mugrientos, en medio de tanta limpieza y luz, parecen llagas" (Martí, Amistad Funesta 194). Esta postura es reafirmada por el propio autor en "Mi raza" donde expresa que: "El hombre no tiene ningún derecho especial porque pertenezca a una raza u otra: dígase hombre, y ya se 
dicen todos los derechos. (...) Todo lo que divide a los hombres, todo lo que especifica, aparta o acorrala es un pecado contra la humanidad" (Martí, Obras Completas 298).

Sin embargo, el plan martiano para el desempeño del indígena en el desarrollo de la república — según el cual se plantea en que: "la libertad, para ser viable, tiene que ser sincera y plena; que si la república no abre los brazos a todos y adelanta con todos, muere la república (...) los gobernadores, en las repúblicas de indios, aprenden indio" (Martí, Nuestra América 20-21) — no se desarrolla a cabalidad en la historia. La representación que se hace de este grupo social no tiene en cuenta sus particularidades socio-culturales, sino que funciona como telón de fondo a un grupo de personajes centrales todos ellos criollos burgueses. Es decir, no se les adjudica un papel relevante en la narración ni se llegan a desarrollar al mismo nivel que su contrapartida criolla. La presencia indígena, además de ser alegórica, es esencialmente un componente contextual. En ella fácilmente identificamos el rostro marginado, víctima del poder colonial que se configura bajo el signo estético del primitivismo romántico y comparte cierta similitud con la universal figura del noble salvaje o en ocasiones es contemplado casi como un elemento folklórico dentro de la narración.

El silencio es uno de los aspectos fundamentales que caracteriza al buen amerindio de Amistad Funesta. Su falta de participación en los diálogos es significativa como también lo es su belleza, digna de alcanzar la categoría artística: "Allá tengo unos inditos en el pueblo que te van a dar asunto para un 
cuadro delicioso" (213), comenta Juan Jerez a Flor del Valle. Hágase notar que el mecanismo estético en la obra martiana se entrecruza con el propósito ético, convergiendo la imagen refulgente con la perfección moral y la idea noble. La dimensión humana objetiva del amerindio se difumina en estas estampas plásticas que evocan una representación nostálgica de un pasado dorado, sobre el cual se afirma que "la conquista hundió en la tierra" (Martí, Amistad Funesta 202)

Amistad Funesta es una novela sentimental, y aunque el punto de vista dominante es el de Juan Jerez, estandarte ideológico del proyecto martiano, quien a su vez encarna el apostolado por la causa indígena; la verdadera profundidad de esta obra se encuentra en el carácter de Lucía. La simbología y el lirismo con que se describen sus celos y pasiones no le restan, muy por el contrario, le añaden importe a su perfil psicológico. La mayor riqueza de esta novela, en mi opinión, se encuentra en la configuración de este personaje. Considero que en la misma se refleja con éxito la problemática del sujeto finisecular, su desamparo espiritual. Las deficiencias en cuanto al detrimento que el concepto de progreso infringe en el hombre contemporáneo quedan claramente expuestas. Igualmente, se cumple a cabalidad el cometido de crítica social, prefigurándose el advenimiento del movimiento indigenista porque, como bien afirma Martí en "Arte Aborigen": "O se hace andar al indio o su peso impedirá la marcha" (Martí, Arte aborigen 330).

Ese Juan Jerez de rasgos mesiánicos que profesa una sublimada fe en la república de todos, al igual que el apóstol, es fundamentalmente un vehículo 
expresivo del pensamiento y los conflictos esenciales de José Martí. Su figura elevada a una condición cristológica se muestra emblemática del pensamiento político del autor. En la misma encontramos los pilares fundamentales del Humanismo realzados a una dimensión sublimada y con una intención esencialmente didáctica. En otra medida, Juan Jerez devela el dilema cultural del apóstol, o sea, su deseo de emancipación intelectual con respecto a la ideología burguesa, de quien es un producto, en paralelo con su incapacidad por penetrar la realidad cultural del amerindio e incorporar su voz. Ángel Rama define esta ambivalencia en Las mascaras democráticas del modernismo al plantear que estos autores -es decir, los modernistas- "asumieron con desparpajo democrático las máscaras europeas, dejando que fluyera libremente una dicción americana, traduciendo en sus obras refinadas un imaginario americano" (169).

Ya bien la representación de la cultura autóctona americana carezca de una perspectiva íntima en gran parte de la obra martiana, especialmente el componente humano, es justo resaltar que su mera presencia constituye una prefiguración del resurgimiento de lo vernáculo en la literatura hispanoamericana posterior, aspecto de alto valor dada la tendencia europeizante en el ámbito cultural de este período. La influencia del maestro, como le llamó Rubén Darío, en autores modernistas posteriores constituye uno de los legados principales del americanismo martiano. Mas aun, viene a ser el sello inaugural, la garantía de que el eclecticismo modernista incorpore un componente puramente americano. 
La anteriormente expuesta representación del amerindio, a tono con esquemas románticos, contrasta con el profundo conocimiento martiano de las culturas prehispánicas. Este tema constituye el punto central de varios ensayos, en los cuales se distingue claramente entre las comunidades tradicionales menos desarrolladas y aquellas culturas dignas de compararse con las más ricas civilizaciones de la Historia. Se defiende la grandeza de las culturas desaparecidas, lo sencillo y lo complejo, la suntuosidad de la arquitectura, el esplendor de las ciudades, quedando bien demarcado que estas comunidades alcanzaron un florecimiento material a despecho de un sistema de vida y pensamiento tradicionalistas. Por consiguiente, las connotaciones desdeñosas implícitas en el léxico burgués, son refutadas por el argumento martiano. Los postulados racistas del positivismo decimonónico quedan desarmados ante la sólida defensa de los valores comúnmente asociados con las culturas primitivas. Martí demuestra que dichos valores no están reñidos con el florecimiento económico y la prosperidad material, en lo que podría enunciarse como una bofetada categórica sobre el rostro de la indiferencia social y el mercantilismo burgués.

Igualmente, Martí entiende que si se han de combatir los criterios racistas del positivismo, es preciso fomentar una educación humanista. Una de las exposiciones más completas y elaboradas sobre el patrimonio cultural del hombre americano antiguo en el discurso martiano la encontramos en el ensayo "Ruinas Indias," publicado en el segundo número de La Edad de Oro (1889). Por tratarse de una revista educativa destinada a la formación del carácter infantil, el 
mensaje ideológico es cardinal. Las minuciosas descripciones hablan a favor de una exhaustiva investigación histórica. Sin embargo, el mérito primordial de este ensayo radica en la claridad del mensaje, accesible a un público infantil sin que se comprometa la complejidad ideológica del texto. En primer lugar, José Martí expone la diversidad de las culturas prehispánicas teniendo en cuenta su nivel de desarrollo, costumbres, formas de expresión, etc., llegando a demostrar nítidamente lo fallido de cualquier intento por reducir la diversidad del hombre antiguo americano a arquetipos, como también lo vano de cualquier intento generalizador.

Seguidamente, se establece un paralelismo entre el mundo clásico, el contexto bíblico, e incluso la moderna Europa, y las culturas prehispánicas. El eje central de esta comparación nos muestra un esplendor quizás superior al alcanzado por la modernidad. Nos habla de lo noble y lo sublime, sobre el sentido de sensibilidad presente en el hombre antiguo, en una exposición de, "héroes, santos, enamorados, poetas, y apóstoles", a la vez que celebra lo monumental de la cultura al describir "pirámides más grandes que las de Egipto", entre otros ejemplos de esplendor. A este respecto cabe señalar que mientras el discurso de poder de la época se centraba en la inferioridad intelectual del amerindio, Martí antepone a este determinismo biológico una lógica fundamentada en fuentes históricas. La tesis martiana en defensa del indio no se basa exclusivamente en el aspecto moral, sino que se edifica sobre la base de un bien documentado inventario de los logros alcanzados por este grupo en condiciones sociales en las que no existía la opresión colonial. Por consiguiente, 
la naturaleza especulativa y carente de fundamento científico de los postulados positivistas se infiere como resultado del análisis martiano.

Martí, además, busca crear una sensación de empatía por parte del lector al ahondar en detalles y estructuras presentes también en el contexto contemporáneo: "circos, templos, canales, talleres, tribunales y mercados". Este sentido de familiaridad es una herramienta clave que ofrece la posibilidad de salvar distancias, de romper la brecha entre el "nosotros" y el "ellos" mientras que permite al destinatario infantil obtener cierta continuidad entre el presente y el pasado americano.

Aunque el tono del ensayo es predominantemente descriptivo, el mensaje anticolonialista aparece de forma explícita en múltiples ocasiones. En la siguiente reflexión se emplean las referencias clásica y bíblica, respectivamente, para ensalzar el carácter del hombre antiguo, y en la empresa se denuncia la violencia del colonizador:

(...) hay oradores que se levantan llorando como el tlascalteca Xicontecal, a rogar a su pueblo que no dejen entrar al español, como se levantó Demóstenes a rogar a los griegos que no dejasen entrar a Filipo; hay monarcas justos como Netzahualcoyotl, el gran poeta rey de los chichimecas, que sabe, como el hebreo Salomón, levantar templos magníficos al Creador del mundo, y hacer con alma de padre, justicia entre los hombres (Martí, Las ruinas indias 381).

Más que una simple defensa de los valores culturales de las civilizaciones arcaicas americanas, la anterior exposición se constituye como una reiteración 
de la postura ético-política implícita en el texto. Inserciones ocasionales como ésta refuerzan el mensaje moral del contenido textual y dan fe del conocimiento que Marti tuvo de la historia y la cultura de estos pueblos.

Por otra parte, el mito de la barbarie del hombre americano se contrapone a un escrutinio minucioso de la crueldad a lo largo y ancho de la Historia, comenzando por la inmolación de vírgenes egipcias, pasando por los sacrificios humanos en la Grecia clásica y culminando estratégicamente con el triste episodio de la Inquisición española:

(...) hubo sacrificios en masa, como los había en la Plaza Mayor, delante de los obispos y del rey, cuando la Inquisición de España quemaba a los hombres vivos, con mucho de leña y de procesión, y veían la quema las señoras madrileñas desde los balcones. La superstición y la ignorancia hacen barbaros a los hombres en todos los pueblos. $\mathrm{Y}$ de los indios han dicho más de lo justo en estas cosas los españoles vencedores, que exageraban o inventaban los defectos de la raza vencida, para que la crueldad con que la trataron pareciese justa y conveniente al mundo" (Las ruinas indias 382$)$.

El mensaje anticolonialista y ético sobresale en este pasaje. Lo "salvaje" en el sujeto americano se distingue de la exposición de la crueldad por parte del hombre "civilizado" en un tratamiento irónico sobre el concepto de barbarie. Con esto se persigue desarmar conceptos anquilosados en el discurso de poder. No debe obviarse aquí la estrategia discursiva de marcar la oposición vencedoresvencidos, recurso que acentúa la postura anticolonialista martiana y muestra la 
perspicacia del analista que delata la manipulación a que había sido sometido el tema de los sacrificios humanos en las culturas precolombinas.

El primitivismo martiano se emplea entonces como un arma política y conlleva a un replanteamiento de los valores y capacidades del hombre americano antiguo. Se desprende que la falta de desarrollo y prosperidad padecidos por el amerindio en el contexto colonial se debe principalmente a un medio ambiente desfavorable, a un entorno que no estimuló el desempeño de sus capacidades natas.

Una más justa representación de la cultura precolombina resulta fundamental si se ha de rescatar a una comunidad venida a menos en el contexto positivista. Por ello, el tema aborigen es retomado con mayor detalle en La América, revista fundada por Martí en su etapa neoyorkina y escenario de la evolución política del autor, especialmente su pensamiento americanista. La ferviente defensa de la humanidad del amerindio comienza con el ensayo ya citado, "Arte Aborigen", breve reseña a propósito de una exposición de arte. Este texto va mucho mas allá del limitado espacio de las salas de un museo, llegando a comunicar un análisis evolutivo de la naturaleza social del indio americano a partir de su expresión artística. Introduce entonces el concepto del desarrollo natural de los pueblos, y de cómo existen edades simultáneas, disimiles entre sí. Al referirse a las comunidades menos avanzadas, prescinde de la deferencia propia del discurso colonial e incluso del concepto romántico del noble salvaje e identifica un momento en la evolución cultural de dichos pueblos, sujeto a mecanismos activos concretos que condicionan un desarrollo ascendente y 
natural, palpable en su labor plástica. Plantea que "Hay pueblos primerizos, (y) pueblos en su segunda época", pero en cada caso distingue entre el arte primitivo y los dibujos infantiles, adjudicándole al primero la seriedad propia de una estética capaz de capturar emociones y sentimientos maduros, de un arte que califica de modernísimo y casi bello.

Igualmente, en el ensayo "Autores americanos aborígenes" testifica a favor de una literatura digna, por su riqueza, de la complejidad social alcanzada en otros aspectos también significativos, como son la estratificación social, el esplendor arquitectónico, y la vida cultural, entre otros. Sitúa a la literatura indígena en un momentum paralelo al período clásico y explícitamente establece vínculos entre La llíada y obras aborígenes específicas; una vez más, sustentando su argumento en sólidas fuentes como son reconocidos americanistas (Daniel G. Brinton) y convenciones de estudiosos sobre el tema (Copenhaughe). Por lo tanto, se puede concluir que la colonización frenó la natural evolución cultural de las civilizaciones americanas. Si bien Martí entiende que revertir este proceso es imposible, propone una revisión de estas fuentes, ya que sin ellas, la identidad cultural del sujeto americano contemporáneo se encuentra incompleta.

Considero particularmente significativa la mención al paradigma del mestizaje precisamente en el corpus de este ensayo, ya que con ello establece un nexo entre su propia voz y la expresión literaria indígena:

¿Qué importa que vengamos de padres de sangre mora y cutis blanco? El espíritu de los hombres flota sobe la tierra en que vivieron, y se les 
respira. Se viene de padres de Valencia y madres de Canarias, -y se siente correr por las venas la sangre enardecida de Tamanco y Paramaconi, y se ve como propia la que vertieron por las breñas del cerro del Calvario, pecho a pecho con los Gózalos de férrea armadura, los desnudos y heroicos caracas! (...) Sólo cuando son directas prosperan la política y la literatura. La inteligencia americana es un penacho indígena (Martí, Autores americanos aborígenes 336).

A este respecto, se ha de tener en consideración que, en América, el advenimiento de la modernidad coincide con la agudización de los conflictos étnicos y políticos a raíz de las luchas independentistas, a consecuencia de los cuales se infiere una significativa preocupación entre ideólogos y políticos, por el concepto de identidad. En el prologo a su traducción de Ramona (1887), novela primitivista de Helen Hunt Jackson, Martí la describe como nuestra novela, defendiendo con ello el carácter mestizo del hombre americano. La hibridez se coloca al centro del debate sobre la identidad y converge con el universalismo modernista y su nueva concepción de un mundo globalizado.

No quiero adentrarme, sin embargo, en los detalles de esta obra por no ser de autoría martiana, pero considero importante su mención por la naturaleza de los planteamientos que Martí hace en su presentación. Ramona es una obra utópica que plantea un proyecto de unidad racial. El personaje principal abandona el mundo criollo y se asimila al modo primitivo del amante, mientras que los indios se consideran a sí mismos ciudadanos de las naciones. En principio, es un planteamiento noble que apela a la sensibilidad primitivista de 
José Martí, sin embargo, no incluye los conflictos políticos del contexto histórico. La interpretación que Martí hace de Ramona como novela emblemática de la identidad cultural americana es una postura regresiva y por consiguiente utópica. Implica un idealismo; comprensible a nivel metafórico, factible como punto de partida o modelo para la creación de un proyecto integrador, pero alejado de la realidad social finisecular.

Durante la estancia en Guatemala, el americanismo martiano se transforma ya que el indio como etnia se convierte en una realidad conocida y experimentada. Tiene entonces el apóstol la oportunidad de acercarse en lo personal a la comunidad indígena y contrastarle con su percepción anterior, de extrapolar concepciones abstractas sobre la cultura aborigen a la hora de configurar un modelo para la nueva república americana y, por consiguiente, plantearse un proyecto más objetivo, con un lugar concreto para el amerindio en la nación oficial. La claridad filosófica y ética con que percibe los conflictos sociales de su entorno le sitúan en un tiempo ideológico desfasado de su momento histórico correspondiente. Se adelanta a las concepciones de su época mostrando principios éticos ultramodernos y a la misma vez se nutre de fuentes antiguas para ahondar en ciertos aspectos de la vida contemporánea que considera en detrimento de una evolución ascendente de la sociedad; aspectos tales como la relación del sujeto moderno con el tiempo, la riqueza, el desarrollo económico, entre otros elementos fundamentales que tradicionalmente definen la relación de cada individuo con su momento histórico. Martí plantea que el sistema de explotación ha resultado en la imposición de 
valores occidentales y ha creado necesidades artificiales que hacen trabajar al amerindio por "cachivaches relucientes mientras que se les niega su dignidad".

Muestra significativa del desarrollo ideológico martiano en este periodo es la obra teatral Patria y libertad o Drama indio (1885), como también se le conoce, que escribiera a petición del gobierno guatemalteco en conmemoración del 15 de septiembre, día de la independencia de este país. Drama indio tiene como tema central el proyecto cultural para la nueva república de Guatemala, así que la problemática del indio es tópico protagónico en la narración. Asuntos como el derecho a la tierra y el lugar social del indio en la naciente república son incluidos de modo integrador y aunque en esta obra dramática todavía se contempla al sujeto autóctono americano desde una perspectiva estética idealizada, el activismo político desde una posición emancipadora prefigura la proximidad del movimiento indigenista.

La obra es un canto a la libertad de América y cuenta con la justicia social, la justicia del indio oprimido, como voz rectora y centro de la narración. Al contar con una composición arquetípica de los personajes, disfrutamos de figuras estructuradas alrededor de principios ideológicos rectores del pensamiento martiano, cuya culminación es precisamente Martino, alter ego del propio José Martí y banderín de la independencia americana. Imposible es ignorar el simbolismo implícito en el nombre de este personaje protagónico o la coincidencia en cuanto a ideales y punto de vista predominante en la narración; es decir, la perspectiva del criollo emancipado y abanderado de la justicia social. Una vez más, con esta obra, el autor proclama el mestizaje emblemático al 
colocar a Martino en una posición estratégica entre Coana e Indiana, representaciones figurativas de las dos Américas (Martí, Patria y libertad). Desde su voz se traza la resolución feliz del conflicto dramático: la independencia política de Guatemala y el subsecuente programa de igualdad social.

La postura anticlerical martiana, a su vez, es manifiesta en el siguiente pasaje de espíritu cristiano radical:

(...) Si mi padre Jesús aquí viniese

Dulce la faz, en que el perdón enflora;

Si al indio viera mísero y descalzo,

Y al Santo Padre que salud rebosa;

Si de los nobles en las arcas viera

Trocada sin esfuerzo en rubias onzas

La carga ruda que a la espalda trajo

India feliz que la fatiga postra;

Si en las manos de uno el oro viera

Y la llaga en las manos de la otra,

¿De qué partido tu Jesús sería? (148).

Nótese la referencia al oro en esta instancia como signo del enriquecimiento déspota del colonizador mientras que en un pasaje anterior se utiliza alternativamente para incorporar principios positivos: ¡Libertad a las almas de los pueblos!/ ¡Truéquese en oro las brillantes joyas! (145). La múltiple asignación de contenido simbólico, como en este caso, a un mismo significante, es característica del movimiento modernista y denota la compleja perspectiva 
desde la cual estos autores perciben y enfrentan asuntos como la riqueza y otros principios rectores de la burguesía. Según afirma Ángel Rama en Las mascaras democráticas del modernismo, el oro:

(...) es una imagen obsesiva, en torno a la cual se rota, a la que se vitupera o alaba, pero de la cual no pueden separarse los escritores. Oscilan entre la tradicional reprobación moral enseñada por la Iglesia y patrocinada por los grupos dominantes y la atracción que inspira su poder en la nueva sociedad, abriendo a sus poseedores codiciados paraísos materiales (...) José Martí reconocía la existencia de la nueva escala de valores de la sociedad regida por el oro. Fiel a su espiritualismo ingénito la censura (143).

Siguiendo este principio, en José Martí vemos una actitud opuesta a la mentalidad de acumulación burguesa. El oro por su valor de cambio es despreciado mientras que se favorece una perspectiva de acuerdo al sistema de valores primitivista. La asociación simbólica entre este elemento y conceptos de importe espiritual coincide con la mentalidad pre-hispánica dentro de la cual el oro en principio carece de un valor material y se constituye fundamentalmente como ofrenda a la divinidad, como vehículo de contenido espiritual. Consecuentemente, José Martí utiliza la imagen dorada siempre dentro de los parámetros de la metáfora para comunicar lo más elevado del espíritu humano. Mientras que en otros autores modernistas vemos una actitud de ambigüedad con respecto a la riqueza, es decir, el rechazo al mercantilismo burgués en paralelo a la creación de ruidosos paraísos materiales y un estilo celebratorio de 
la estética del lujo, José Martí es muy coherente y en su actitud prima la austeridad.

La simiente ideológica modernista comienza en el modo en que José Martí incorpora la emergente modernidad a su plan político y a su filosofía vital. El uso de lo autóctono como mecanismo discursivo de su retórica antiburguesa crea cierta ambivalencia entre el indio visto desde el punto de vista metafórico y el indio como individuo concreto. A la misma vez, las profundas diferencias de clase y los prejuicios que ensombrecen a las naciones americanas hacen eco en el humanismo martiano, en vehemente reacción contra la herencia positivista. Su proyecto de nación el cual hace extensivo a toda Latinoamérica es uno democrático que incluye a todos. Si bien este carece de un modelo concreto, ya sea porque la labor independentista le absorbe, ya por su marcado idealismo y tendencia a la utopía política, Martí clama por la participación de cada segmento marginado en la naciente republica. Garantizar al hombre americano con todos sus rostros: el criollo, el negro, el indio, el mestizo...un lugar en la sociedad es la máxima meta del americanismo martiano.

\section{I.2 Rubén Darío: Las Grutas Fundadoras De Un Primitivismo Modernista}

A diferencia de José Martí, Rubén Darío se inclina hacia una postura ideológica mucho menos explicita, en consonancia con ese momento en el que el modernismo representa en el ámbito literario la universalidad de una época globalizada. Menos urgido por sus circunstancias socioculturales y personales, instaura un diálogo más directo y, aparentemente, armónico con Europa y la 
Modernidad; un diálogo donde la actitud crítica subyace bajo un léxico altamente codificado -propio del estilo modernista dariano que, aunque mucho más presente en sus textos anteriores al cambio de siglo, suele ser considerado el modernismo por antonomasia- en el que, aún así, podemos entrever como una reacción antagónica a la industrialización y el materialismo burgués.

En desacuerdo con algunas corrientes críticas, pienso que desarraigo no es precisamente el término de elección que nos permita calificar la introspección y el repliegue en la escritura de Darío. Lo sutil en su arte es mucho más que un modo de auto-preservación ante una nueva realidad que amenaza con devorar al artista y su autonomía. La coherencia ideológica del maestro adquiere en el discípulo una nueva vestidura: el exotismo en sus más variadas formas. Pero no debe pensarse que se trata tan solo de una cuestión formal, el mismo Darío aseguró en El canto errante:

No es, como lo sospechan algunos profesores y cronistas, la importación de otra retórica, de otro poncif, con nuevos preceptos, con nuevo encasillado, con nuevos códigos. Y, ante todo, ¿se trata de una cuestión de formas? No, se trata de una cuestión de ideas (Darío, El canto errante 9)

De modo que la ruptura a nivel expresivo que estos autores encarnan implica un cambio en términos de cómo esbozar y entender el desarrollo histórico bajo una nueva propuesta que es el credo modernista. El artista se independiza de los mecanismos culturales existentes y con dicha emancipación reclama una posición marginal desde la cual interpretar la historia. En aquel punto, los 
discursos nacionalistas del romanticismo resultaban una praxis intelectual obsoleta por la complejidad de los nuevos tiempos que reclaman la articulación de nuevos modelos. En correspondencia, el descontento del artista ante los paraísos arrebatados por la modernidad se haya inscrito en esa mirada cultural fugitiva y los elementos exotistas hablan a favor de un método de resistencia por medio de la imagen poética. Esta tendencia que va a predominar durante todo el movimiento, es el resultado de la natural decepción del artista ante los derroteros del fin de siglo, quien vuelve entonces su mirada hacia otros espacios menos materializados ya sea por intermedio de la imaginación o de la distancia temporal y/o espacial.

De este modo se consolida una corriente literaria innovadora cuya herramienta fundamental es la creación de mundos artificiales. En las convenciones estilísticas del exotismo orientalista, en los cuentos de hadas y otros arcaísmos es posible encontrar un sistema de ideas subalterno donde el pensamiento mítico pre-moderno se subordina a la forma en articulado artificio plenamente consciente de sí mismo y carente de la ingenuidad propia de un pensamiento primitivo auténtico. En este sistema poético, la relación consciente entre forma y subtexto es el punto de partida para la creación de una nueva mitología afín con la modernidad en un proceso que Ángel Rama supo entender, según plantea en Crítica literaria y utopía en América Latina, como una sinfonía de la escritura:

Darío se abalanza (...) sobre un material milenario, el depósito cultural íntegro de Europa incluyendo sus paseos exóticos por el Oriente, el cual 
sólo era accesible a los americanos por la intermediación de libros y objetos artísticos. Procede a una recomposición que quizá Levi-Strauss hubiera definido como un típico proceso de bricolage característico del pensamiento salvaje y también, como apunto en su libro, de todo pensamiento estético. Se trata de una composición de segundo, tercero, o cuarto nivel: dada una rica y heterogénea acumulación de productos culturales, reconocerlos como tales en sus particularismo inmodificables, pero someterlos a combinaciones que los redistribuyesen, alterando radicalmente por lo tanto sus valores originales, asociarlos en una captación sincrónica y mezclarlos a otros materiales, naturales o no, que disciplinadamente ingresan al nuevo orbe artificial (Rama, Crítica literaria y utopía en América Latina 149-150).

Mi aproximación a la figura de Rubén Darío dentro de esta investigación tiene lugar desde un interés en su papel de fundador, y por ello me centro en aquellos aspectos que guardan una relación con lo primitivo y a la vez resultan significativos para las tendencias rectoras del modernismo. Corresponde destacar a este punto que en su estética, el contacto con el primitivismo es más bien tangencial, pero decisivo en marcar direcciones que luego otros autores, y el mismo Darío, profundizarán en el primer cuarto del siglo XX.

Con respecto a la conflictiva relación entre lo europeo y lo americano, si bien se ha querido encontrar una inquietud creciente por lo autóctono en el poeta, el camino ascendente hacia un mayor americanismo da fe no sólo de una preocupación personal sino también de la continuidad en la literatura modernista 
de uno de los tópicos más antiguos en la historia cultural americana, o sea, el tema del mestizaje. El considerar a Rubén Darío como poeta de América ha de ocurrir desde su condición bicultural -sin dudas acá cabría el prefijo poli, pues nada le fue ajeno-, o sea, desde una posición que abarque la mirada itinerante hacia Europa, hacia lo más profundo americano y hacia el mundo todo.

Amador de la cultura clásica, me he nutrido de ella, mas siguiendo el paso de mis días. He comprendido la fuerza de las tradiciones en el pasado, y de las previsiones en lo futuro. He dicho que la tierra es bella, que en el arcano del vivir hay que gozar de la realidad alimentados de ideal. Y que hay instantes tristes por culpa de un monstruo malhechor llamado Esfinge. Y he cantado también a ese monstruo malhechor (Darío, El canto errante 13-14).

Esta premisa presupone la fusión de diversas mitologías -indígenas, asiáticas, grecolatinas, etc.- y de símbolos occidentales en un producto que busca recontextualizar el pasado por medio de la consolidación de lo tradicional en un nuevo artefacto cultural. En ese marco, el eclecticismo acuña la producción de un nuevo concepto de identidad y ya en "Coloquio de los Centauros," el autor se da a la tarea de explorar el concepto de hibridez desde una visión sincrética para luego examinarlo con mayor definición en la prosa:

El monstruo expresa un ansia del corazón del Orbe, En el Centauro el bruto la vida humana absorbe, El sátiro es la selva sagrada y la lujuria, Une sexuales ímpetus á la harmoniosa furia. 
Pan junta la soberbia de la montaña agreste

Al ritmo de la inmensa mecánica celeste;

La boca melodiosa que atrae en Sirenusa

Es de la fiera alada y es de la suave musa;

Con la bicorne bestia Pasifae se ayunta,

Naturaleza sabia formas diversas junta,

Y cuando tiende al hombre la gran Naturaleza,

El monstruo, siendo el símbolo, se viste de belleza (Darío, Prosas profanas y otros poemas $90-91)$.

Como bien se refleja en este fragmento, la polaridad que encontramos en la figura del centauro es uno de los elementos icónicos de la escritura dariana. Toda experiencia humana $y$, por ende, la literaria, es naturalmente contradictoria; pero el modernismo lleva la antítesis como lema, tal vez porque sus recursos poéticos buscan más la emoción que el significado y, entonces, las significaciones de sus textos se vuelven casi equiparables a sus lecturas. El simbolismo dual es un elemento clave que nos permite constatar una visión crítica ante la riqueza y el progreso tempranamente articulados en las imágenes orientalistas.

Es así que el objeto representado adquiere una connotación negativa cuando ejerce su función crítica mientras que cuando encarna valores de una elevada espiritualidad, se muestra entonces estéticamente grato. Igualmente, cuando dicho objeto se haya en su condición de censura, se enmarca en un lenguaje negativo. Como ha advertido Araceli Tinajero en Orientalismo en el 
modernismo hispanoamericano: "los objetos asiáticos, los cuales no son una copia del orientalismo francés sino que revelan una presencia en América desde el siglo XVI, representan una crítica a la acumulación de riquezas"( 34 ). Así en "El rey burgués", "La emperatriz de la China" y otras historias, la acumulación de chinerías y japonerías se opone a la materialización y esquematismo de la belleza resultado del utilitarismo burgués a la vez que se convierten en portavoz de la exigencia de una mayor libertad para definir lo sublime y, a la vez, la instauran.

Esta doble mirada a lo oriental en los textos y su función estética reflejan una mayor inquietud espiritual como consecuencia natural de la crisis que generó el positivismo. Enfocarnos en el lenguaje elíptico y la imagen desbordada nos lleva entre otras cosas a una conciencia de la nimiedad del individuo en el contexto decimonónico mientras que la desmesura en el lenguaje produce monstruos, imágenes oníricas que evidencian el horror humano por la deshumanización de la civilización. Igualmente, es visible en la reiteración de esta temática una preocupación por destacar lo icónico y lo contradictorio como un espacio de encuentro y enfrentamiento de opuestos a la vez que ofrece la posibilidad de escapar al tiempo y a la circunstancia.

La anterior aproximación presupone una afinidad con lo grotesco, la cual encuentra paralelos en la literatura gótica del romanticismo. Lo mórbido marca el tono en gran parte de los textos y desde una perspectiva visual, la realidad maravillosa permite explorar la elaboración de un cuerpo de imágenes en ocasiones monstruosas, establecer una relación entre el absurdo y los sueños y 
ofrecer una visión del mundo regida por fuerzas ocultas donde lo insólito conduce a una decodificación de la realidad social del artista, como en la grotesca e irónica imagen final de "El velo de la reina Mab": "Y desde entonces, en las buhardillas de los brillantes infelices, donde flota el sueño azul, se piensa en el porvenir como en la aurora, y se oyen risas que quitan la tristeza, y se bailan extrañas farándolas alrededor de un blanco Apolo, de un lindo paisaje, de un violín viejo, de un amarillento manuscrito" (Darío, Azul 43).

En la misma línea se sitúa la aproximación a eros en el pensamiento rubendariano. La crítica coincide en apreciar lo mórbido y lo erótico como dos temáticas centrales de la prosa que se entremezclan entre sí. Si ahondamos en esta relación veremos que la obsesión por la muerte y lo sensual son expresiones únicas de una misma filosofía, expresiones concretas de una visión de mundo panteísta y natural. Sólo por la pasión erótica en el arte y sus misterios nos acercamos a lo trascendente, y ese acercamiento en Darío se da por medio de la descripción carnalizada de cuerpos femeninos en contextos festivos y con recursos generadores de sinestesia.

Hay mucho de pagano, de primitivo, en ese erotismo que se desborda en "La ninfa", donde Lesbia "se entretenía en chupar como niña golosa, un terrón de azúcar húmedo, blanco entre las yemas sonrosadas” y exclama: “iBah! Para mí los sátiros (...) si esto fuera posible, mi amante sería uno de esos velludos semidioses. Os advierto que más que a los sátiros adoro a los centauros; y que me dejaría robar por uno de esos monstruos robustos" (Darío, Azul 29-30). Y toda esa invocación de lo erótico de matices violentos conduce a la pregunta del 
sabio: “¿con qué derecho negamos los modernos hechos que afirman los antiguos?" (Darío, Azul 30). No pueden caber dudas, Darío ha visto ninfas.

Esta visión del erotismo como actualización de un proceso cósmico, eterno, se convierte en un rechazo y una censura implícita a la racionalidad. El encantamiento ante la idea del amor, tan incomprensible como la propia muerte, resulta en la articulación simbólica de un imaginario que en ocasiones produce en el lector una impresión de angustia casi metafísica, de violencia telúrica, como en "El rubi", donde la descripción de las piedras preciosas formando parejas -los finos diamantes y las colgantes calcedonias, las resplandecientes esmeraldas y los amontonados zafiros- sirve de contexto al irracional e incontenible deseo del otro: "Brazos, espaldas, senos desnudos, azucenas, rosas, panecillos de marfil coronados de cerezas" (Darío, Azul 53) y, como consecuencia, "la gran masa diamantina se teñía de grana" (Darío, Azul 54).

En otras ocasiones lo erótico va más allá de un interés concreto, se despersonaliza y se transforma en un placer estético suscitado por estereotipos. Al ser la mujer burguesa del siglo XIX confinada al espacio interior, separado del trasiego moderno, representó un refugio para el artista, como sucede con la prima Inés, "¡Sana y virginal primavera!" (Darío, Azul 68), para el narrador de "Palomas blancas y garzas morenas". Ángel Rama supo advertir muy bien estos significados asociados al sujeto femenino en la obra de Darío al afirmar que:

Al margen de las críticas que hoy podamos formular sobre las limitaciones y deformaciones que ello ejerció sobre su condición, la mujer apareció en la época como un ser resguardado de las nuevas circunstancias sociales, 
voluntariamente segregado de sus imposiciones alienantes y situada en una suerte de hornacina bella donde subjetividad y sensualidad podían desplegarse (169).

El papel relevante de estas princesas erotizadas llevará a una de las tendencias centrales del modernismo: la sensación. La misma se extiende a toda practica discursiva en autores como Enrique Gómez Carrillo que entonces la convierten en la expresión rectora de toda su escritura, como se verá en el siguiente capítulo.

Una mirada al tratamiento de lo religioso también devela un contacto con el pensamiento mítico. Este tópico suele estar acompañado de un paganismo subversivo, en el cual prima el efecto inquietante. Los relatos de tema cristiano, son de pronto asaltados por la presencia de lo mágico y, con ello, el misterio que es la religión de la antigüedad se abre paso. A partir de aquí se puede entender que la magia opera en el centro mismo de su pensamiento porque se vincula en sus estratos más profundos a las fuentes originales de la imaginación religiosa. En su excelente estudio sobre el pensamiento religioso de Darío, Thomas Ward demuestra que: "la visión unificada del cosmos que posee Darío no solo sintetiza el dogma católico con los sistemas esotéricos, incluyendo en estos el pitagórico, sino que lo sintetiza también con el panteísmo, la base de su pensamiento consciente" (Ward 368).

Esa búsqueda de asideros espirituales es una muestra de su rechazo de la industrialización y la materialización de la vida contemporánea; pero los asideros del poeta van más allá del cristianismo, hacia las religiones y los mitos 
antiguos y lejanos, como intentando llenar un vacío irremediable. Este fracaso de la religión y esa búsqueda tienen un correlato en sus ideas sobre la ciencia moderna. Uno de los objetivos centrales de toda la literatura modernista fue oponerse al pragmatismo positivista y su elevadísimo concepto de lo concreto y experimentable. Cathy Jrade, estudiosa de este tema, asegura que:

Rubén Darío (...) aborda en varias piezas en prosa las tensiones entre la ciencia y el conocimiento trascendental que la literatura provee como alternativa satisfactoria y persuasiva o complementaria a las creencia religiosas (...) en una sociedad que privilegia, prácticamente por encima de todo, a las realidades empíricas y pragmáticas (Jrade 162).

El naufragio de la ciencia y la religión en su esfuerzo por develar los misterios esenciales de la vida según queda expuesto constituye una afirmación de la actualización de la estructura mítica y del poder de la creación humana. La literatura, la poesía, viene en auxilio del poeta, como en los pueblos antiguos, cuando la distinción entre esas ramas del saber humano aún no existía y un verso era conjuro y axioma de la vida.

Esa base primitiva del pensamiento creador del poeta nicaragüense extiende sus efectos hacia su concepción del tiempo. Conocida es la fascinación del autor por la obra de Herbert George Wells, patente en un artículo que dedicó a su Time Machine en $1904 .{ }^{6}$ Pero desde 1884 Darío mismo venía

\footnotetext{
${ }^{6}$ Es destacable, por las implicaciones que tiene la defensa de lo hispano frente a lo anglosajón como paralelo del enaltecimiento de lo primitivo frente a lo moderno, que en este artículo Darío sugiera que el verdadero inventor literario de la máquina del tiempo sea Enrique Gaspar y Rimbau y no H. G. Wells.
} 
experimentando con el tiempo en sus relatos. En el cuento "El caso de la señorita Amelia" el Doctor Z es incapaz de explicarse lo sucedido con esta niña que no ha crecido después de veintitrés años: “¿Quién conoce a punto fijo la noción del tiempo? ¿Quién sabe con seguridad lo que es el espacio? Va la ciencia a tanteo, caminando como una ciega". Debo destacar que ante esa imposibilidad de la ciencia moderna para explicar el misterio, el Doctor Z intenta ilustrar a sus convidados con otra sabiduría, pero a ellos no les interesa. He aquí sus palabras otras, orientales: “¿Sabéis cuáles son los principios del hombre? Grupa, jiba, linga, shakira, kama, rupa, manas, buddhi, atma, es decir: el cuerpo, la fuerza vital, el cuerpo astral, el alma animal, el alma humana, la fuerza espiritual y la esencia espiritual" (Darío, El caso de la señorita Amelia).

El tiempo detenido, la estructura circular de ciertos cuentos, el desencanto por la ruta de la historia, que no siempre asciende sino que se retuerce, nacen de la ya comentada oposición del escritor al positivismo imperante. Un punto cardinal de este antagonismo, muy relacionado con la concepción del tiempo y de la historia, es la polémica relación de Darío con la idea de progreso. Si bien sus letras contribuyen a la instauración de la Modernidad en Hispanoamérica, si bien gusta y aprecia Darío de los beneficios y adelantos modernos; no cabe duda que también cuestiona el ansia insaciable del progreso por su carácter devorador y por la subordinación que impone al alma bajo la materia. 
Aunque presente desde relatos de Azul como "El fardo", "El rey burgués" o "La canción del oro", la formulación más contundente y conocida de este cuestionamiento es la que aparece en su poema "A Roosvelt":

Eres soberbio y fuerte ejemplar de tu raza;

eres culto, eres hábil; te opones a Tolstoy.

Y domando caballos, o asesinando tigres,

eres un Alejandro-Nabucodonosor.

(Eres un profesor de energía,

como dicen los locos de hoy.)

Crees que la vida es incendio,

que el progreso es erupción;

que en donde pones la bala

el porvenir pones.

No.

La fuerza de este fragmento emerge, por un lado, del desenmascaramiento que el poeta realiza de los sentidos asociados en la Modernidad a la palabra "progreso", específicamente aquí en la extrema significación de ese termino para la cultura estadounidense. Allí donde solo ven crecimiento eterno, Darío ve también destrucción, por la violencia que engendra, violencia que vio y padeció como hombre y poeta; allí donde solo ven la libertad de un destino manifiesto, Darío pronuncia un No rotundo. De la reducción magistral de las silabas del verso, generando un ritmo climático, casi catastrófico - de los alejandrinos a una categórica sílaba-, proviene también la fuerza de este fragmento. 
Frente a esa América confiada en el progreso Darío opone la América Nuestra, cuyos atributos son la poesía, los mitos y la telúrica fuerza de su naturaleza y de su historia. Escrito en 1903 -e influenciado por acontecimientos como la toma del Canal de Panamá- el poema saca a la superficie una arista de ese primitivismo fundador que aprecio en la obra de Darío y que junto a sus criterios sobre la ciencia, su defensa del erotismo, sus enriquecimiento de lo religioso con diversas corrientes y su aprecio por lo mítico, lo antiguo, lo exótico, conforma una obra de originalidad sin par y sienta también las bases del primitivismo que analizare en la obra de otros autores modernistas. 
CAPITULO II EL JAPÓN EN LA CRÓNICA DE ENRIQUE GÓMEZ CARRILLO, UNA MIRADA A SU FILIACIÓN PRIMITIVISTA

La inmensa obra de Enrique Gómez Carrillo —más de ochenta libros—abarca la mayoría de los géneros en prosa: crónica, ensayo, narrativa e, incluso, propaganda política; pero donde más se destacó su pluma fue en el primero de ellos, lo que le valió el calificativo de "Príncipe de la crónica". Variados fueron los temas que abordó en ellas, pero los viajes realizados durante su vida fueron siempre el material fundamental de la escritura. El viaje, ese es el gran motivo de su producción literaria, al punto de que llega a convertirse no solo en un móvil literario sino, también, en un símbolo del paso del hombre por la vida, en un móvil vital.

El otro elemento que aúna su prosa no ficcional es el de las sensaciones que el viaje produce Este tema de la sensación es recurrente en su obra y va desde el título de alguna de ellas —De Marsella a Tokio: sensaciones de Egipto, la India, la China y el Japón (1906) — hasta la recurrencia de la palabra y sus sinónimos en el interior de los textos. En un texto de temprana escritura y abundante reedición —“La psicología del viajero" (1910)— que ha sido considerado como ensayo, pero que muchas veces se ha publicado junto a sus crónicas, Gómez Carrillo deja constancia de la interrelación que ambos motivos: el viaje y las sensaciones que produce, poseen en su obra: "Por mi parte, yo no busco nunca en los libros de viaje el alma de los países que me interesan. Lo 
que busco es algo más frívolo, más sutil, más positivo: la sensación" (Gómez Carrillo, Crónicas e impresiones de viajes 7).

Su criterio no es de poca importancia para esta investigación, pues el contexto en el que Gómez Carrillo realiza esta declaración es el del debate entre los escritores-viajeros sobre la posibilidad de atrapar el alma de los pueblos que se visitan; en otras palabras, es el mismo contexto del que iba surgiendo la antropología cultural. No debe engañarnos, tampoco, el calificativo "frívolo" especialmente porque viene acompañado de "sutil" y "positivo"-, ya que se corresponde con las maneras modernistas. Las sensaciones son el modo en el que el observador se deja invadir por la otredad y la devuelve en sus textos. No hay pretensiones científicas ni descriptivas, el cronista nos muestra mucho más que una geografía. Ofrece un viaje espacio-temporal en el que conocemos, más que la cultura ajena, la huella que deja en el cronista lo vivido.

Ahora bien, esa huella tenía ya un molde preestablecido: el de la cultura libresca del autor. Ha leído mucho Gómez Carrillo sobre esas tierras que visita, y las sensaciones del viaje real se van mezclando con aquellas del viaje literario que ya había realizado. La mayoría de las veces el pie del cronista se siente cómodo en la huella que sus antecesores dejaron; pero en ocasiones se rebela y es entonces, a mi juicio, cuando mejor florecen sus sensaciones, cuando más certeramente alcanzan al lector contemporáneo.

Por otro lado, la insistencia en las sensaciones viene muy a tono con la estética modernista, donde la sinestesia es un recurso de empleo recurrente. Al establecer una correlación entre semejante actitud literaria ante lo visto y las 
artes plásticas, de inmediato se nota la cercanía al impresionismo. El artista nos muestra lo que ve, pero en el tiempo y desde la perspectiva que más lo han impresionado. Es aquí donde radica, para mí, la más efectiva diferencia entre los textos de Gómez Carrillo y los de otros viajeros que le antecedieron y que tanto cita en su obra: en la selección, en el pulso que mantiene con esa realidad de acuerdo a sus intereses $y$, por supuesto, en las sutiles correcciones. Esa arraigada condición de flaneur queda explícitamente expresada en otro de sus libros: "Dos horas de indolente contemplación en la terraza de un café sirven mejor al viajero curioso que muchos días de febriles excursiones, porque no es lo mismo pasar ante la existencia que dejar pasar a la existencia ante nuestra vista" (Gómez Carrillo, La sonrisa de la Esfinge 26-27).

La aparente frivolidad con que se disfraza la crónica de Enrique Gómez Carrillo conduce necesariamente al equivoco. Ya bien descriptiva y profusamente sensorial, la voz literaria que encontramos resulta muy consciente de su realidad histórica. Seduce y enamora al lector a la misma vez que considera las particularidades de su tiempo. Carrillo se circunscribe a la difusión de productos exóticos y del placer del viaje como bien de consumo en sí mismo, en el contexto de un universalismo cultural de moda; el cual se hace posible a partir del auge de las exposiciones universales y de una mayor movilidad geográfica producto de la industrialización. La suya, no obstante, va a ser una obra de estructura compleja que trasciende las pautas del género y nos brinda una perspectiva muy personal con una bien definida agenda y un trasfondo ideológico. 
Debido a la impronta empírica y al tono de autoridad inherentes al discurso periodístico, la pluralidad conceptual en esta crónica al igual que su ficcionalidad quedan enmascaradas y supeditadas a la función informativa del discurso. La intención de fomentar una ideología, no tiene cabida en la sensualidad de la crónica, pero aun así, tras la aparente superficialidad del texto se esconde un componente subversivo que desafía a la modernidad en lo que defino como un intento desesperado de trascender el vacío al que se enfrenta el individuo, en especial el artista, en el contexto decimonónico.

\section{II.1 De Marsella A Tokio: La Primera Mirada Del Otro}

Uno de los viajes que mayor material dio al cronista para su obra fue el subsidiado por los rotativos La Nación, de Buenos Aires, y El Liberal, de Madrid, a Japón. La Meca de los sueños modernistas se hacía realidad para Gómez Carrillo, quien convenció a los directores de ambos periódicos de que los lectores estaban ansiosos por saber cómo era ese Japón que había derrotado a Rusia. Por supuesto que sus crónicas fueron mucho más allá de un reportaje político y se convirtieron en un testimonio sociocultural de los pueblos que visitó.

Gracias a la magia del lento viaje de inicios del siglo $x x$-lejos de nuestros vuelos sin escalas y nuestros trenes de alta velocidad- Japón no fue el único país que conoció el cronista. Un viaje a Japón, el fin del mundo, era también un viaje a cada uno de los puntos intermedios. De Marsella a Tokio el viajero podía experimentar y digerir el paso de Occidente al Extremo Oriente. Tal 
es el material que nutre la primera parte del libro inicial del autor sobre este trayecto, una especie de antesala a la cultura paradigmática del Oriente.

Debe destacarse que la edición príncipe del libro ya venía acompañada de un prólogo de Rubén Darío en el que la figura cumbre del Modernismo elogia la pasión de Gómez Carrillo y toca el tema que acá interesa bajo el matiz de la influencia europea en Oriente. Darío se muestra convencido de que la cultura japonesa no cambia en su esencia, por mucha levita y sombrero de copa que hubieran importado. Su seguridad viene a ser reforzada por una carta de Gómez Carrillo que cita en el prologo:

He tenido una deliciosa desilusión. En vez del país europeizado y americanizado de que hablan los publicistas serios, he encontrado el delicioso pueblo de los abanicos (...) Fuera de Tokohama que es internacional, fuera de los métodos industriales y de los sistemas guerreros que son europeos, todo sigue siendo lo mismo que antes (Gómez Carrillo, De Marsella a Tokio. Sensaciones de Egipto, la India, la China y el Japón VIII).

Indirectamente el corresponsal cuestiona la visión de los publicistas, interesados en atraer hacia el Japón los grandes capitales, y se regocija de haber podido disfrutar aún de cientos de detalles de la cotidianeidad japonesa que persisten.

Aunque deliciosa, no debe desdeñarse su "desilusión”, y mucho menos olvidar la causa: la estandarización de los productos culturales que nos impiden ver la realidad del Otro. Así continúa la carta que Darío cita: “¡No es lo que habíamos soñado! ¡No es lo que habíamos visto en los cromos! Pero luego los 
ojos se acostumbran, (...) un amor de lo japonés nace en nuestras almas. Uno se acostumbra á eso hasta el punto de desear hacerse japonés, para vivir á la japonesa" (IX). El cronista tiene el valor de confesar que se ha equivocado tanto como los otros viajeros y propagandistas — literatos, artistas, comerciantes-, y se declara definitivamente vencido por el alma japonesa. Desde el prólogo mismo, porque evidente fue para el prologuista, la literatura de viajes de Enrique Gómez Carrillo se nos presenta como un dialogo entre el saber adquirido en la cultura Occidental y aquel otro saber que la experiencia misma del viaje, las sensaciones, le van aportando.

Pero el periplo hacia Japón y el verdadero conocimiento del Oriente había comenzado mucho antes, en Marsella, puerto mediterráneo que Carrillo llamará "verdadera puerta del Oriente", tal vez porque en la mayoría de esos puertos europeos, cuya vida se desarrolla de frente al Magreb, ya se constataba, desde siempre, un reconocimiento del Otro no experimentable en las eurocéntricas ciudades modernas que Carrillo había habitado.

En el barco mismo, el Sydney, conoce a militares europeos que regresan aliviados a sus puestos. Representantes por excelencia del eurocentrismo, guardianes de esos intereses imperiales ingleses para quienes, sin embargo, el viaje hacia el Oriente, cada vez, era un viaje de liberación: "Europa les parece estrecha (...) sus rostros expresan lo contrario de la nostalgia, el deseo de huir de las ciudades civilizadas, de perderse en espacios inmensos, de correr peligros y de descubrir tierras" (24). En esa "cosmopolis flotante" conoce también al sabio chino Ta-Yen, seguidor de la hipótesis de que América fue 
descubierta por "un Colón amarillo". Su sabiduría y porte lo convierten en el hombre más imponente del viaje.

El trayecto va matizado de paisajes que van adquiriendo el misterio propio de lo primigenio. Como en el Mar Rojo, frente a la volcánica isla Perim, dominada pírricamente por un batallón inglés cuyos oficiales se suicidan constantemente, acosados por la naturaleza ardiente, por el horror de una luz natural desconocida y constante; o frente al Sinaí, "cuyo prestigio es superior a las creencias, puesto que domina las imaginaciones de todas las razas" (32).

El tema de la dominación británica del Oriente, recurrente en todos los viajeros de la época, aparece desde la llegada a Egipto. Pero, a diferencia de esos mismos autores, muchos de los criterios políticos que se encuentran en la obra de Gómez Carrillo no se manifiestan en la voz del narrador, sino por medio de lo que la investigación —periodística o antropológica- llamaría, hoy, informantes. Que sea un habitante mismo de estas tierras quien dé su opinión socio-política aumenta la veracidad y el dramatismo del discurso y, de un modo muy conveniente, protege al autor de polemismos y represalias.

Donde quiera hallará Carrillo "amigos" dispuestos a esta clase de comentarios, como el egipcio que le confirma que el imperialismo inglés no es el único que ha estado presente en esas tierras, y que, por suerte, ha estado acompañado por la dominación francesa, "cuya influencia moral es un bálsamo perpetuo para nuestras heridas de amor propio nacional" (35). Para un absoluto propagandista de la cultura francesa como Carrillo, las palabras del egipcio 
vienen como anillo al dedo: cuestionan y alaban, respectivamente, bandos tradicionalmente enfrentados.

El narrador reconoce la labor de transformación que la dominación inglesa ha ido realizando en Egipto, hasta modelarlo a su imagen y semejanza. Un aspecto crucial de esa tutela es la transformación en la escala de valores relacionada con el trabajo: el turismo, tan cuestionado por otros viajeros, ha modificado drásticamente "las ideas sobre la necesidad de trabajar para comer" (37). Pero su amigo egipcio sabe que las ansias de liberación perviven y se nutren del primitivo país de los faraones: "El antiguo Egipto no esta muerto. Los musulmanes y los cristianos han podido dominarlo, pero no transformarlo. Un soplo nacional fuerte, bastaría para hacer desaparecer los turbantes y los cascos coloniales" (36).

Idénticas sensaciones sobre la labor inglesa patentiza el cronista en los textos sobre la India; pero con una diferencia: sin un amigo indio que se enfrente a la dominación, el narrador solo la ensalza, hasta el punto de llamarla "labor evangélica" (61). No obstante, como para suavizar su entusiasmo modernista, cita a un discípulo de Anatole France con el que —casual y convenientementeconversó: "Los verdaderos enemigos de la política colonial debemos odiar más la liberalidad inglesa actual que la antigua ferocidad española. Vea usted, si no, los resultados. España ha perdido su imperio, mientras Inglaterra, después de la independencia americana, lo ensancha" (65).

No puede afirmarse, sin embargo, que Carrillo sea un defensor acérrimo de ese status quo. Tan solo es un escritor correcto y mesurado. Si leemos entre 
líneas notaremos las ironías que se deslizan en el texto sobre el poder británico y sobre su centro mismo: la majestad de Victoria y de su heredero, como cuando empleando un juego de palabras nos describe el modo en el que enfrenta la Metrópolis la más mínima rebelión de una de sus colonias: "Y cuando, por casualidad, un estado se muestra celoso de su autonomía política, su graciosa majestad, graciosamente se lo acuerda" (64).

Sí, Gómez Carrillo es un hombre de su siglo, que gusta del desarrollo de la Modernidad que la colonización ha impuesto; pero no aprueba sus métodos. Y Gómez Carrillo es también un sensible escritor, amante de las culturas y sus manifestaciones socioartísticas. Todas esas vías férreas y cada uno de esos ropajes modernos, de hormigón o de tela, con el que se van cubriendo, respectivamente, los cuerpos de las ciudades y los cuerpos de sus habitantes no impresionan su imaginación como la estampa de las tradiciones, como la huella del pasado que, aunque en ruinas y en vías de desaparición, todavía produce "suntuosas evocaciones":

Á medida que las palmeras de Colombo van perdiéndose á lo lejos entre los vapores azules del horizonte, la noción exacta de la realidad que acabamos de ver desaparece de nuestra memoria. Diríase que materialmente una mano borra, una por una, las sensaciones de vida, de comercio, de modernidad. (...) Pero en cambio las cúpulas ruinosas de las pagodas, los muros roídos de los palacios, las colinas llenas de piedras dispersas, las estelas en que aún se ven caracteres herméticos, todo lo antiguo, todo lo que es evocación de un pasado glorioso, lo que 
habla de fastos abolidos, de suntuosidades muertas, de poderío desvanecido, lo que es leyenda brillante, en suma, toma, en nuestro recuerdo, ó mejor dicho, en nuestra imaginación, proporciones inmensas (81).

De manera que el cronista sabe ver debajo de la modernidad que él mismo representa, y sabe dejarse impresionar por lo primitivo, por el peso de la leyenda sobre la vida, por la continuidad entre la naturaleza y la cultura en estas tierras. "iOh divina mansedumbre! Pájaros y hombres, todo inspira respeto piadoso á aquel pueblo" (89). Y, como explicando esa sorprendente mansedumbre en tan gran pueblo, propone la leyenda como el refugio final de una civilización que va siendo arrasada. El siguiente pasaje, con el que Carrillo resume un fragmento que dedica a la historia de la India, marca negativamente la llegada europea y ofrece la explicación que comentaba:

Los europeos aparecen al fin. $Y$ entonces, sorprendidos como en medio de un divino sueño de poderío sinfín, de riquezas infinitas, de pompas eternas, los hijos de los antiguos conquistadores vuelven hacia el pasado sus ojos melancólicos, y huyendo de la realidad que los hace esclavos de razas bárbaras, se pierden en la contemplación de sus leyendas, mientras los muros de sus palacios van derrumbándose piedra por piedra (90).

En ese dialogo entre modernidad y primitivismo, la balanza da un vuelco con la llegada a China. Es sorprendente la lucidez con la que Gómez Carrillo aprecia los efectos del desarrollo moderno en Asia y sus posibles consecuencias, tanto para la región como para el planeta. Los primeros signos de este fenómeno los 
encuentra en Singapur. Los criterios del cronista sobre la responsabilidad europea y las consecuencias de lo que se conocía como "el peligro amarillo" llevan al autor a emplear su socorrida estrategia del informante. En esta ocasión es un profesor de francés quien, desde su experiencia como nativo, le proporciona la otra cara de la moneda en esta polémica. Para él, el freno a la modernidad en la región viene de la casta mandarín, pero no duraría mucho tiempo. Resulta notable en el siguiente pasaje el velado cuestionamiento a los métodos europeos y la contradicción entre esa modernidad impuesta y la tradición:

El peligro es pacífico. No amenaza los puertos de guerra, sino los puertos comerciales. (...) Pero esto no debiera sorprender á los europeos. ¿Acaso no son ellos los que se han empeñado en educar á ese inmenso pueblo que antes vivía contento en su retiro? Después de abrir brechas á cañonazos en la gran muralla, han exigido que se les permita traficar. Han fundado bancos, almacenes, depósitos, compañías, vías férreas, fábricas. Los chinos, en un principio, rieron. (...) Después de las sonrisas irónicas, el examen serio ha comenzado. Unos veinte millones de chinos tienen ya nociones vagas de progreso moderno. Poco á poco, gracias a la sutileza de la raza, los problemas religiosos que hoy se oponen al adelanto, irán resolviéndose, y entonces las leyes que prohíben construir edificios de más de noventa y nueve pies de altura para "no impedir el libre vuelo de los espíritus aéreos", ó clavar clavos en el suelo para "no herir á los dragones subterráneos" caerán en desuso (93-94). 
Y así ha sido. Y si los occidentales no vieron el verdadero peligro se debió a su mirada colonialista, incapaz de valorar justamente la fuerza de la cultura diferente, cargados sus ojos de estereotipos y prejuicios como los que asociaban al asiático con la pasividad y la degeneración. Ante la realidad del muchacho que arrastra el carro en el que se pasea con el profesor de francés, el cronista europeo pierde ese velo positivista: " $i Q u e ́$ diferencia entre él y los celestes de las estampas! Fuerte y ágil, es una respuesta viva á los que hablan de degeneración física de la especie" (95).

Como si la luz que esa realidad sorprendente y vigorosa lanza sobre sus conocimientos librescos lo enardeciera, el cronista llega a criticar los modales europeos y a celebrar esos amplios saludos de la cultura asiática. Saludos que el mismo oriental ha ido sustituyendo por los occidentales, aunque los considere groseros y ridículos, porque "ofrecen grandes ventajas prácticas" (97).

El pragmatismo inoculado por los mismos europeos es la base del verdadero peligro chino. En este aspecto, la lucidez de Carrillo y de su amigo profesor de francés es pasmosa: "Los cien millones de soldados cubiertos de armaduras que los visionarios contemplan con espanto en un porvenir pavoroso, serán, realmente, cien millones de obreros" (103); y, más adelante, cuando los mandarines ya no estén: "Ese día, el peligro amarillo será una realidad. Ese día, la más vasta, la más formidable democracia obrera, habrá declarado la guerra á la industria occidental" (105).

Luego de semejantes predicciones, el recorrido continua por Indochina, por la tierra de los anamitas y por Corea. De estos lugares el narrador nos deja 
estampas de mayor apacibilidad y contacto con la naturaleza. En Saigón, por ejemplo, cree ver los bulevares parisinos, pero al anochecer se impone la calurosa brisa asiática sobre los enormes arboles y, mientras se adormece la civilización, reaparece la esencia del lugar, en este caso representado por la naturaleza.

Lo mismo sucede en el capitulo dedicado al fumadero de opio anamita, con la diferencia de que ahora la hipnótica planta, y no la brisa, provoca el embotamiento de los sentidos, y de que la substancia del mundo oriental se encarna en el cuerpo del otro. La descripción de este lugar — dominado por la presencia de un ser encantador y misterioso que acapara la atención del cronista y el texto mismo- es uno de los pocos momentos del libro en el que no hay interrupciones intelectuales ni comentarios de convenientes allegados. El cronista se deja conducir por lo erótico y, bajo los narcóticos efectos, se llena de una sensación muy genuina que provoca un fragmento de singulares valores y cuyo punto culminante es la pregunta sobre el sexo de la figura inmóvil, que se transmuta en una interrogante sobre su naturaleza misma: ¿fantasma o realidad?

Toda la vida de ese ser estaba en sus ojos, paradójicamente, también inmóviles. A ellos dedica Carrillo este fragmento donde la pedrería modernista se cubre de un autentico y tradicional traje japonés:

¡Aquellos ojos! Yo me asomé a ellos, como a un pozo infinito, con espanto y beatitud. En su fondo flotaban las visiones del ensueño asiático. $Y$ eran, en barcas de jade, entre sederías rutilantes, princesas 
del Yunam (...); y eran piratas heroicos luchando en sus frágiles sampans contra las naves formidables del emperador; y eran dragones tutelares, de escamas de mil colores (...); y eran palacios grandes como pueblos, palacios de filigranas (...); y eran, allá, muy en el fondo, muy en el fondo, bajo las aguas del pozo, minúsculas pagodas milagrosas (116).

La delicadeza y el arcano de esos ojos contrasta con la grotesca monumentalidad de Shanghai, cuya descripción le sigue. Industrializada y moderna, con sus "altas columnas humeantes" sus "muelles de hierro", sus "millares de barcos" y su "tumulto vertiginosos". Un verdadero hormiguero humano donde todo es enorme, monstruoso, formidable; un laberinto informe que —esta frase traduce impecablemente la sensación del autor- "se describe mejor con cifras estadísticas que con frases" (120).

A las puertas de Japón, en Corea, el apacible mundo oriental reaparece de la mano de la literatura: "solo las artes y las letras de un país han servido eficazmente para dar idea de su alma" (125). Aunque no ha leído más que una novela coreana, esta le sirve para valorarla por su ingenuidad y por "el sentimiento de la naturaleza que anima todas las escenas" (126), rasgos que apuntan hacia el primitivismo. Para ilustrar su criterio, Carrillo cita largamente la novela que ha leído, cuyas descripciones son muy cercanas a la que el mismo realizó del fumadero por su relación con el paisaje y con los símbolos de esa cultura. Su talante de critico literario occidental lo lleva a comparar constantemente el texto con la literatura europea; para ensalzarlo, sí, pero 
opacando esa diferencia en el tratamiento de lo natural que ya había encontrado y que encerraba el verdadero valor del texto coreano.

Ya está en Japón, en las puertas del Imperio del Sol Naciente. Nosotros, como lectores, en el fin de su viaje de Marsella a Tokio, pero en el centro de este libro y en el inicio de los otros que dedicó a este país de ensueño para la estética modernista.

\section{II.2 El EXotismo Japonesista De Gómez CaRRILlo O La INTELECtualización De LO PRIMITIVO}

Japón ocupa un espacio singular dentro de toda la visión orientalista de Enrique Gómez Carrillo (1873-1927). El país nipón que el cronista nos dibuja es "heroico" y es "galante" en disonancia con el tono decadente que predomina en el resto de su obra, postura contrastante que conduce al cuestionamiento sobre la naturaleza de tal distinción y cuya clave, pienso, se encuentra en la construcción y el descubrimiento de un modelo iconográfico a partir del cual se subvierten los fundamentos burgueses de la modernidad.

Como se ha apreciado, en la concepción gómez-carrillista sobre la modernidad finisecular resalta cierta ambigüedad. El progreso material, referencia continua, es descrito con cierto tono celebratorio, en oposición a la búsqueda incesante de un ideal primitivista en el seno de la tradición. "El Japón antiguo no ha muerto," afirma Carrillo reiteradamente. Desde su visión, el Imperio del Sol ha conseguido mantener intacto su halo identitario, adaptándose 
a lo novedoso desde una posición selectiva y de conservación de los valores culturales autóctonos.

Podría afirmarse entonces que, para él, la sociedad moderna ideal ha de ser progresista en un plano material, mientras que debe conservarse primitivista en arte y espíritu. En mi opinión, su viaje hacia el Oriente —el real y el simbólico- se origina en la aspiración de conceptualizar un ideal artístico en el contexto de la expansión burguesa. Desde su punto de vista, la comunidad universal ha de beneficiarse de este paradigmático país, celoso depositario del legado antiguo de un pasado dorado, como bien recoge la siguiente opinión:

Las civilizaciones de todos los países deben reunirse en el Japón; y el Japón transformará esas civilizaciones por su influencia propia y dotará al mundo de una civilización única y verdadera. Esta es la misión particular del Japón, la que debe perpetuar eternamente su influencia (...) El Japón debe ser el centro del mundo por razones eternas, imputables, independientes de poderíos y guerras (DMT, 218).

El encuentro con el orientalismo japonés se convierte entonces en un modelo para la autorreflexión, un espacio sobre el cual proyectar una identidad universal en crisis. Si partiésemos de una comparación con el típico orientalismo escapista de otros autores modernistas — Julián del Casal, por ejemplo- encontraremos que Carrillo trasciende la influencia parisina para fabricar un exotismo propio; con frecuencia, cuestionando lo leído en autores europeos como Lafcadio Hearn y Pierre Loti, y estableciendo su propia perspectiva a partir de la experiencia directa. Una aparente necesidad de precisión histórica lo lleva con frecuencia a 
comparar su experiencia con lo leído en estas fuentes, es decir, a discrepar de estos modelos o a reafirmarlos.

En este sentido, entiendo la crónica japonesa de Enrique Gómez Carrillo, —repartida fundamentalmente en tres obras: De Marsella a Tokio (1906), El alma japonesa (1907) y El Japón heroico y galante (1912)— como una invitación implícita a examinar la condición del hombre moderno desde la alteridad. En correspondencia, la selección temática sobre la cual se estructuran los relatos se dispone en torno a los primordiales valores épicos japoneses, como son la cortesía, el honor y el sacrificio. En este proceso de observación, la realidad se ajusta a un ideal pre-determinado con la consecuente representación de una nación idealizada. El viaje de Enrique Gómez Carrillo al Japón, a diferencia del resto de su trayectoria itinerante, es un viaje interior hacia el centro de las tradiciones antiguas.

Muy a pesar de la primacía de una perspectiva que pudiésemos definir desde la otredad, es decir, la visión del hombre occidental desde su inevitable distancia cultural como punto de vista dominante; existe un manifiesto deseo de acercamiento, una voluntad de participar de la realidad del otro y comprenderla. El estilo de exploración de Carrillo difiere del procedimiento del viajero común que describe la ciudad desde sus exteriores. Por eso, en el puerto de Yokohama —que no es más parecido a San Francisco de lo que él esperaba— se burla de los turistas ingleses, manipulados hasta el tuétano por la escueta y bien pagada descripción que Ruyard Kipling había realizado del Japón: 
Para ver eso han pasado cuarenta días en un buque; para ver eso han gastado cinco mil francos en el billete de ida y vuelta; para ver eso se han resignado á no oír la plática evangélica durante cinco domingos. ¡Y encontrarse ahora con una ciudad que lo mismo podría ser holandesa que canadiense, ó alemana, ó escandinava! (Gómez Carrillo, De Marsella a Tokio. Sensaciones de Egipto, la India, la China y el Japón) (Gómez Carrillo, De Marsella a Tokio. Sensaciones de Egipto, la India, la China y el Japón 142)

Pero, a pesar de sus lecturas y sus saberes, Gómez Carrillo sabe encontrar una perspectiva propia. Él nos mostrará una visión interior conformada desde el predominio de los espacios cerrados como son las casas de té y los templos, reflejo de una aspiración de acercamiento profundo a la cultura: "Al penetrar en el recinto sagrado, una impresión de sobrenatural se apodera del alma. La suntuosidad en la delicadeza es alucinadora" (Gómez Carrillo, De Marsella a Tokio. Sensaciones de Egipto, la India, la China y el Japón 165).

Ese gusto por los espacios cerrados como reflejo del alma típica japonesa posee un correlato en su continua referencia a los modales nipones, especialmente a las sonrisas y las reverencias, gestos que están presentes en la vida del Japón desde las ceremonias publicas hasta la más llana cotidianidad. Es precisamente la sonrisa de una mujer lo que devuelve a Carrillo la sensación de estar en Japón en un pasaje de De Marsella a Tokio en el que insiste en las diferencias entre el país soñado y la realidad que se presenta a sus ojos. Al final de este mismo libro dedica crónicas exclusivas a ambas gestualidades, signos 
inequívocos de la cortesía japonesa; pero es en el siguiente pasaje donde mejor se ve la convergencia entre los espacios íntimos y tales maneras, y donde, de paso, no deja de comparar el autor las diferencias entre el ajetreo Occidental y la parsimonia del Oriente:

Y en el tren minúsculo, más pequeño, más ligero que un tranvía madrileño, el movimiento peculiar de toda llegada se inicia, pero no como en Europa, no con febriles impaciencias y curiosidades infantiles, no con ruido ni con alegría, sino grave y pausadamente. (...) Antes de ponerse de pie, los caballeros arreglan de un modo escrupuloso los nobles pliegues de sus kimonos obscuros. Luego, para pasar la mano entre dos vecinos con objeto de buscar sus diminutas maletas de bambú, hacen reverencias, muchas reverencias, cuatro, cinco, seis reverencias. ¡Y qué reverencias! Los cuerpos se inclinan hasta tocar el suelo con las manos. (...) Las sonrisas también son las mismas. Cada movimiento supone una sonrisa. Las mujeres, sobre todo sonríen perpetuamente; las viejas más que las jóvenes, las niñas más que las viejas (Gómez Carrillo, De Marsella a Tokio. Sensaciones de Egipto, la India, la China y el Japón 145).

Me parece oportuno en este punto resaltar el contraste con relación a los cronistas de la conquista de América, ya que salvando la gran distancia cronológica, el auge de la modernidad ejerció un impacto similar al efecto globalizador de la colonización, pues significó una amenaza sobre la individualidad de aquellas culturas que consideraríamos periféricas con respecto 
al epicentro hegemónico. En este caso, el cronista, mas que conquistado por el encanto y la promesa del Oriente, aspira a ser transformado por sus valores, los cuales estima superiores, herencia de una edad dorada. El contacto de Enrique Gómez Carrillo con el Oriente se traduce en un encuentro dinámico cuyo resultado es la subversión de la perspectiva propia. En palabras de Araceli Tinajero:

Lo interesante es que su recorrido fue hecho inmediatamente después de terminar la guerra ruso-japonesa. Como Japón ganó la guerra, el escritor se dirigía hacia una nueva potencia oriental. Ese hecho influyó de una manera impactante a que cuestionara los poderes coloniales a través de su viaje. Al mismo tiempo se ocupó de darle la voz a los orientales y en esa forma presentó diferentes puntos de vista. No sería arriesgado decir que su libro es una crítica al colonialismo europeo aunque claro, esto no quiere decir que no respetara a los europeos sino que mas bien era crítico de las transformaciones del mundo moderno (Tinajero 19).

Uno de los elementos claves a considerar en la formulación de la crítica a la modernidad en Gómez Carrillo es el hecho de que entre su mirada y el Japón se interpone un acervo de literatura antigua, evidente en la multiplicidad de referencias literarias en el cuerpo textual; fenómeno que, como hemos visto, no posee un carácter exclusivo de la crónica japonesa. Pero, si bien Carrillo intercala referencias, principalmente procedentes de la literatura de viajes $-y$ esto de modo indiscriminado en toda su crónica-, la japonesa posee un elemento folklórico único. Los relatos son ilustrados con pequeñas narraciones 
de ficción, de forma que el Japón idealizado ha de considerarse fruto directo de su bagaje literario, donde el objeto de la mirada se filtra a través del tamiz de la ficción. Su sensibilidad de hombre occidental ha sido conquistada mas que por el exotismo modernista y por la realidad nipona, por la literatura folklórica japonesa.

En ese conocimiento de la historia literaria nipona debe destacarse un elemento único: la presencia de la mujer escritora en el canon literario. En otro de los libros dedicados a este país, El alma japonesa, Gómez Carrillo reserva un epígrafe para el tema de las escritoras en la poesía Nara y en el periodo Heian: Murasaki Sikibri, viuda retirada a un convento para escribir la historia de un príncipe azul; Sei Sonagon, cuyo libro "Notas de mi almohada" recuerda al cronista que en el año 1000, "mientras los europeos se morían de miedo pensando en el fin del mundo, [los nipones] solo pensaban en vivir, en gozar, en amar" (Gómez Carrillo, El alma japonesa 131-132); Akazomé Yemon, cuya historia de la época clásica japonesa es la más notable; y, entre muchas otras mujeres escritoras, la viajera Abutzu, en cuya obra, como en la del cronista hispanoamericano, "mas que aventuras, hay paisajes, cielos, puestas de sol, espectáculos de belleza" (Gómez Carrillo, El alma japonesa 138). El lugar que estas mujeres alcanzaron en la sociedad nipona antes del siglo XIII le sirve para exaltar los valores primitivos y contrastarlos con la realidad europea. Por eso afirma: "El desprecio que los japoneses tienen hoy por la mujer, no es un sentimiento originario de la nación. Galantes y caballerescos, los antiguos 
nipones demostraban, al contrario, por sus compañeras, un respeto tal vez mayor que el de los europeos" (Gómez Carrillo, El alma japonesa 127).

Me atrevo a afirmar, dado el conocimiento literario evidente en toda la obra gómez-carrillista sobre el Japón, que la representación que hace de la nación oriental responde a una adaptación de la realidad a partir de estas fuentes. $\mathrm{Y}$ es precisamente el lugar que ocupa la ficción en la producción del ideal lo que sustenta la construcción de una utopía cultural primitivista. Entre esas fuentes se encuentran la historia del poeta Tadanori, que el cronista conoció por el texto Cerezo de Suma; o la del hermano del caudillo Atsumori, "otra leyenda, también fielmente histórica"; o aquella de los cuarenta y siete ronis, "los santos más respetados de la religión samurái". Baste ahora el ejemplo del bandolero Goemón, cuyo sacrificio y amor por su hijo ilustran perfectamente la heroicidad idealizada que nutre la mirada del cronista hacia la cultura primitiva japonesa:

En el momento de morir lo llevan hasta el borde de la caldera, y le dicen: "Precipítate allí con tu hijo; defiéndelo de la muerte si puedes". Él sonríe y se arroja al fondo de la substancia infernal, teniendo a su hijo en los brazos, que salen de la pez. Y su cuerpo se quema, y su vida se escapa; pero los brazos continúan enhiestos, crispados, sosteniendo al niño fuera de la caldera (Gómez Carrillo, De Marsella a Tokio. Sensaciones de Egipto, la India, la China y el Japón 209)

En uno de los acostumbrados diálogos con nativos, naturalizados o especialistas afloran, también, su admiración por la narrativa japonesa y el conocimiento que 
había adquirido al respecto. Se trata de un elogio de la tradición literaria y sus hiperbolizaciones, mantenidas "sin mancha ninguna de influencia occidental, ni aun de japonismo moderno" (Gómez Carrillo, De Marsella a Tokio. Sensaciones de Egipto, la India, la China y el Japón 176). En esta herencia literaria oral —la crónica se titula "Los contadores de cuentos", no debe olvidarse que la llamada oralitura es uno de los rasgos centrales de lo primitivista— lo trágico y lo erótico ocupan un mismo lugar relevante, porque no existe la estrecha moral europea. Tan hiperbolizadas y mezcladas se encuentran ambas actitudes que Carrillo, cuyos escarceos eróticos son tan conocidos, termina ruborizándose y dejando los movimientos del erotismo japonés a la imaginación encendida del lector:

- Los contadores de cuentos no saben hacer sonar sino dos notas: la escabrosa y la trágica. Cuando no desnudan, descuartizan. $Y$ en uno y otro caso son de una exageración increíble. Figúrese usted que se trata de un asesinato. Una puñalada no les basta. Es necesario que el malhechor se encarnice y que proceda como los verdugos chinos. Primero corta una pierna, luego arranca la piel, en seguida saca los ojos, después abre el vientre, al fin despedaza el corazón, el cráneo, el rostro. Y mi amigo agrega:

-En las historias amorosas proceden del mismo modo.

En ese caso, ya comprendo (Gómez Carrillo, De Marsella a Tokio. Sensaciones de Egipto, la India, la China y el Japón 178).

En correspondencia con tales fuentes, la crónica gómez-carrillista adopta una estructura de fábula en torno a un conjunto de tópicos periféricos en relación con 
el ideario progresista de la Modernidad. En primer lugar, sobresale una crítica tácita a la urbanidad, presentada como una sobrevaloración de la afinidad que el ciudadano mantiene con su entorno natural. Según Gómez-Carrillo, el japonés venera al paisaje como a una religión, llegando a exhibir la presencia de cierto panteísmo poético: “(...) los chiquillos viven en verdadera comunión con los seres vegetales que son sus primeros amigos" (Gómez Carrillo, El Japón heroico y galante 223); y luego añade la siguiente reflexión sobre la incidencia protagónica de la naturaleza en el diario devenir del ciudadano:

(...) ir a ver una llanura cubierta de flores o un lago en cuya superficie nadan los lotos sagrados; subir a una montaña azul o contemplar una puesta de sol tras un bosque de criptomerias; extasiarse ante un riachuelo que canta entre las peñas...; acudir, en una palabra, a cualquier sitio famoso por su hermosura natural con la voluptuosidad con que se acude a una cita de amor, constituye para los japoneses el mayor de los placeres. Los más humildes como los mas ricos organizan partidas de contemplación lo mismo que nosotros organizamos partidas galantes (Gómez Carrillo, El Japón heroico y galante 225).

En el segmento anterior resalta la opinión contrastante, la perplejidad ante un modo de vida espiritualmente superior a la vanidad occidental. Pasajes como este, en el que Japón y Occidente son comparados tangencialmente, abundan en la narración, y van marcando una definida afinidad ideológica hacia el sistema tradicionalista oriental. A la misma vez, en los relatos predomina una visión incompleta del paisaje urbano, pues la mirada de este novecentista vacila 
ante los elementos citadinos, los cuales, por lo general, son presentados incidentalmente, mientras que enmarca aquellos aspectos del ambiente que perduran de una era pre-industrial. $\mathrm{Y}$ esos elementos primitivos merecen lo mejor de su prosa modernista, convirtiendo cada paisaje en un poema más que en un escenario. En el parque Ueno el cronista tiene la sensación de que un poema se ha encarnado en el crepúsculo que describe:

En el parque mismo, bajo los árboles centenarios, el aire tiene color de azafrán y de perlas. Hay blancuras imprevistas en el ambiente; blancuras que palpitan en los aleteos de las palomas que pasan camino de las pagodas lejanas; blancuras que se inmovilizan en los cálices de los lirios; blancuras sagradas de tooris de piedra que custodian las puertas de los templos; blancuras del aire, incomprensibles; blancuras etéreas que se desvanecen y que aparecen de nuevo; blancuras de velos feéricos... Y son las perlas del verso que me obsesiona. En cuanto al azafrán, helo allí, también, formando en el confín de las alamedas una valla de luz; helo allí en los techos rojos de los santuarios búdicos; helo allí en los pétalos de los lotos que flotan en los estanques..." (265).

De cualquier modo, el cronista hubo de tener experiencias significativas de metrópoli, pues el desarrollo de Japón en el siglo XIX se equipara al alcanzado por Hispanoamérica, especialmente en lo referente al auge de la urbanización. Y ese "progreso" era palpable en muchos sentidos $y$, al igual que en Hispanoamérica, adquiría por momentos tintes ridículos, anacrónicos, por su desconexión con la tradición y por su carácter incompleto. Pocas veces es tan 
aguda la ironía gomezcarrillista como en el pasaje sobre la hiper-abundancia telefónica de Tokio. Luego de una descripción hermosa y modernista, dedicada a la ciudad luego de la lluvia y a su gente, estalla, en contraste, la crítica al progreso: "Y para colmo de males, el progreso, que no se ha acordado de hacer aceras ni de poner alumbrado publico, ha sabido, en cambio, aumentar el horror de lo que ya existía, con la novedad de sus hilos telegráficos y telefónicos" (155). El teléfono —invento sin igual y orgullo de Occidente- carga con el peso de una pretendida e impuesta "civilización" y se convierte en la crónica en un signo grotesco de la inoperancia y el daño de la injerencia occidental:

La historia del «teléfono en cada habitación», aun en las de los mendigos, no es una leyenda. En donde no hay ni cama ni trajes, hay teléfono. En las esquinas, en todas las esquinas, se ven kioscos con un letrero que dice : «Teléfono público». ¡Y así, lo europeo se reduce á algunos sombreros hongos y á muchos aparatos telefónicos! (Gómez Carrillo, De Marsella a Tokio. Sensaciones de Egipto, la India, la China y el Japón 155)

Por otro lado, Gómez Carrillo se da a la tarea de re-conceptualizar el lugar del japonés en la sociedad a la usanza de las comunidades primitivas. Mientras que el individualismo burgués se abre paso en el contexto histórico del siglo XIX. Le procura al sujeto japonés una posición secundaria con respecto a la comunidad entre descripciones exageradas que en ocasiones despersonalizan completamente al protagonista del relato. Las temáticas llegan a convertirse en los verdaderos héroes, arquetipos del perfecto ciudadano, a la par que el 
individuo común es transformado en un personaje de leyenda. Asuntos como el honor y la abnegación dominan el relato y conforman un universo supeditado a los elevados principios de una sociedad ritualista, guerrera, y altamente poetizada.

Al sacrificio de la propia vida el autor le llama: "morir en belleza" y añade: "Todos envidian la suerte de aquellos que supieron morir con elegancia por un motivo fútil" (Gómez Carrillo, El Japón heroico y galante 173). Esta representación de un pueblo legendario y contrario al individualismo burgués, donde los samuráis de antaño, con toda su ceremonia y voluptuosidad, son una presencia viva, resalta de varios modos en las diferentes crónicas. La encontramos en la madre que celebra el patriótico sacrificio de un hijo, en el suicidio por honor y en la moral que bordea a la guerra, tan diferente a Europa, tan pre-moderna y que, como veremos, va desapareciendo.

Esos pasajes dedicados a la reciente guerra entre Rusia y Japón son los únicos en los que el cronista aborda directamente el tema que usó como pretexto para financiar su viaje a Oriente. Sus comentarios no dejan de comparar y favorecer al Japón, como cuando alaba el respeto con el que trataron al obispo de la Iglesia Ortodoxa Rusa y al templo mismo durante la guerra, elogio que encierra una deliciosa oposición entre "pueblo japonés" y "populacho europeo": "No, verdaderamente el pueblo japonés no ha imitado nunca la conducta de los populachos europeos, que para probar su entusiasmo guerrero comienzan por hacer manifestaciones contra las casas en que viven ministros y cónsules del país enemigo" (185). 
Y, sin embargo, Gómez Carrillo reconoce que algo ha cambiado, pues el código samurái comienza a ser quebrado por el nuevo código europeo. El pueblo quiere una indemnización, y aunque algunos quieren el oro y la plata para fundir un puente y un palacio, monumentos a la victoria; otro lo quieren constante y sonante en sus bolsillos. Los conceptos de Kyuso, que el cronista cita, tan alejados del espíritu occidental moderno, que ven el juego del comercio como un juego invertido en el que se pierde, al ganar, el honor, no rigen ya el espíritu publico japonés después de esta guerra muy siglo XX. El lamento del cronista incluye en la actitud occidentalista, por vez primera, a los Estados Unidos de América, que comenzaba a ser ya el centro económico mundial: “(...) por desgracia, los partidos políticos se empeñan en disminuir la nobleza de este gesto, obligando al pueblo á obrar á la manera europea, á la manera yanqui, á la manera del comerciante moderno de sangre, que sabe de antemano el precio que los vivos deben pedir por sus muertos" (Gómez Carrillo, De Marsella a Tokio. Sensaciones de Egipto, la India, la China y el Japón 194-195).

Menos consternado se muestra el cronista respecto a la influencia de la ciencia Occidental en el Japón. Nos la presenta como una expresión más del modo como el japonés asimila el progreso y lo adapta a su visión de mundo: "Hay, en efecto, sistemas [de conocimiento] que en Alemania, en Francia, en Inglaterra, no pasan del laboratorio o del gabinete de estudio. Los japoneses se apoderan de ellos y los llevan a la escuela, es decir, a la masa del pueblo (...) no hay en Tokio un solo catedrático que no este contento de lo que todos juntos hacen" (Gómez Carrillo, De Marsella a Tokio. Sensaciones de Egipto, la India, la 
China y el Japón 200). Al ser la ciencia un producto moderno, el hecho de que su recepción suceda dentro de los parámetros culturales del Oriente japonés implica una conservación y celo de la propia identidad, testimonio de ese ideal que Carrillo ha salido a buscar en su viaje.

En un terreno similar, la esencia de la poesía nipona, a su vez, según la describe, refleja un estilo arcaico, disonante con respecto a la literatura moderna, y específicamente, a la estética modernista per se.

(...) un poema Japonés es siempre un epigrama en el sentido helénico de la palabra. El poeta trabaja, sobre todo ideológicamente, y desdeña, o mas bien desconoce, lo que es labor de artífice, esfuerzo de artista, cultura de orfebre. Lo que le interesa es sugerir o evocar mucho con pocas palabras, haciendo con las cinco líneas de un tanka lo que aquellos maravillosos paisajistas del siglo XVIII hacían con la esbelta ondulación de un solo rasgo (Gómez Carrillo, El Japón heroico y galante 188).

Este modo de poetizar, al cual el autor llamó "un pensamiento disimulado entre palabras", implica una reflexión peculiar e inaccesible para el hombre occidental. Consiste en un proceso de escritura ideográfico desde el hermetismo de la cultura japonesa. De igual modo procede con la arquitectura, especialmente con la de tipo religioso, donde aprecia una encarnación absoluta del espíritu tradicional japonés.

Frente a la pagoda no surgen las habituales discrepancias entre realidad y ensueño que entorpecen la comprensión europea de lo japonés. Nada de lo que contengan libros y estampas de publicistas europeos sobre el Oriente puede 
compararse a ese "milagro de arte". Incluso más, nada de lo que el mismo cronista pueda contarnos hará justicia a la arquitectura sagrada de Nikko. Por eso calla, por eso se refugia en las palabras de Kippling, no sin antes arrastrar por el piso el aldeano orgullo de la arquitectura europea:

Sí; la palabra humana no puede nunca traducir esas maravillas de arte, de gracia, de luz, de armonía, de suntuosidad. Decir, por ejemplo, que las más espléndidas arquitecturas europeas son miserables si se comparan con éstas, no parece sino una frase. En realidad es algo más, puesto que es una sensación. ¡Pero qué diferencia entre la intensidad con que se experimenta y la palidez con que se expresa! Las únicas palabras que convienen para este caso, son aquellas de Rudyard Kipling que rezan: «Esto ha sido hecho como hubiese podido hacerlo un dios». Es todo lo que puede decirse (Gómez Carrillo, De Marsella a Tokio. Sensaciones de Egipto, la India, la China y el Japón 168).

Semejante admiración contrasta radicalmente con los criterios que patentiza sobre la arquitectura religiosa católica y protestante y, particularmente, sobre la catedral rusa de Tokio:

Aquí, donde todo es delicado, florido, ligero; (...) aquí en el imperio de lo fino, de lo vaporoso, los rusos han venido á edificar esa masa enorme y sombría. Los católicos mismos, á pesar de su actual gusto detestable, y los mismos protestantes cuya estética es mediocre, habían respetado hasta cierto punto el instinto artístico del país; y no pudiendo dejar de levantar torres de mampostería y muros de prisión, siquiera habían tenido 
el tino de esconder el conjunto entre enramadas admirables (Gómez Carrillo, De Marsella a Tokio. Sensaciones de Egipto, la India, la China y el Japón 182).

Los aspectos que he presentado hasta ahora ilustran una afiliación primitivista cuyo punto álgido veremos que descansa en la manipulación del sujeto femenino. La figura de la musmé se abre paso en la imaginación modernista, sumándose a un conjunto de símbolos del Oriente de influencia decisiva. Su presencia en el salón de fiesta europeo y en el arte novecentista en general es el lógico resultado de la globalización cultural decimonónica. Carrillo hace referencia a este hecho en la crónica "Sadda Yacco" a quien describe del siguiente modo: "La hemos visto a ella, flor carnal, cortesana sensitiva, loto blanco de jardín lejano, vivir, en un instante, toda una existencia de frívolos amores y luego morir con una sensibilidad hasta hoy nunca vista en el teatro" (Gómez Carrillo, De Marsella a Tokio. Sensaciones de Egipto, la India, la China y el Japón 237).

Empero, la incidencia de la geisha en la crónica gomez-carrillista, responde a una función específica, y es la de satisfacer el interés de la audiencia por lo audaz, por el tema atrevido, el cual Carrillo supo manejar muy acertadamente y que luego profundizó en sus novelas erótico-sentimentales: Tres novelas inmorales (1898), El misterio de la vida y de la muerte de Mata Hari (1923) y El evangelio del amor (1927). Fue un maestro en cumplir con las exigencias del género periodístico —es decir, en respetar las imposiciones editoriales y mantener el interés de los lectores_- al mismo tiempo que insertaba 
su ideología en el subtexto, una ideología que puede ser considerada antiburguesa y antimoderna. Se apoya en la musmé como uno de los componentes más perdurables y aparentemente estáticos de la tradición japonesa. Y con ello, su manejo de lo exótico, más que una apropiación del sujeto o el establecimiento de una perspectiva desde la postura del colonizador, es un modo de afincarse en la tradición de cara a la globalización cultural.

La geisha ennoblecida se convierte en una puerta de acceso a los misterios de la cultura japonesa y representa ante los ojos de Carrillo el perfecto modo de penetrar su ideal. Se lanza entonces, impúdico, al interior del universo geisha, en lo que podríamos definir como un deseo simbólico de intimidad con la cultural oriental.

La importancia de este encuentro queda establecida en la siguiente referencia a las "vendedoras de sonrisas" tras la llegada del cronista a Tokio, entre invocaciones al panteón Shinto: "Y gracias a ella, (...) a su esplendor de leyenda, la vulgaridad de esta plaza de estación desaparece y un Japón admirable surge ante mis ojos extasiados" (Gómez Carrillo, De Marsella a Tokio. Sensaciones de Egipto, la India, la China y el Japón 150). Como bien afirma Ivan A Schulman en Painting Modernism (2014), la sexualidad de la musmé es para Enrique Gómez Carrillo un ritual sublimado a una condición sobrehumana, un acto sagrado. Para él, estas "cortesanas de aspecto sacerdotal" representan el depositario mas intacto de la tradición antigua. De aquí que se establezca claramente su distinción frente a la mujer de pueblo: 
Estas damiselas de los kimonos suntuosos, que ostentan en las mangas el blasón de sus familias bordado en campo blanco, son de un ámbar claro y traslucido, sin mancha ninguna de sangre obscura, y apenas mas morenas que las españolas de Andalucía. Las otras, en cambio, son de color de bronce, lo mismo que las indias de América (Gómez Carrillo, El Japón heroico y galante 25).

Dichas "otras" son percibidas como criaturas en un estado natural pre-moderno, según explica con mayor detalle en el siguiente pasaje:

En el campo, niños y niñas van desnuditos hasta la edad de diez años. ¡Pero que digo en el campo! En Tokio, en Kobe, en Yokohama, en Osaka, en todas las grandes ciudades, es frecuente ver a las mujeres con el torso completamente desnudo, dando de mamar a sus hijos en las puertas de sus casas. En cuanto a los hombres que reman en los canales, de un extremo del imperio al otro, van lo mismo, es decir, sin mas traje que un taparrabo, un simple taparrabo de salvaje (Gómez Carrillo, El Japón heroico y galante 153).

Mientras que así desmitifica a la mujer real, desde su desnudez, la sexualidad de la idílica geisha se entiende como un rito sacro que ocurre en medio de una profusión de vestiduras: "Es ella que llega ya no rígida dentro de su traje dorado de dragones y de quimeras, sino envuelta en un ondulante kimono de tul claro. ¡Es ella! Las dos maikos la acompañan hasta la orilla del lecho (...) Y por fin, siempre sin prisa, las servidoras leales cubren el nido con un velo verde" 
(Gómez Carrillo, El Japón heroico y galante 33-34). Es un encuentro intimo, sin llegar a violar el misterio y los secretos de la hermética cultura geisha.

En apariencia, el nivel de sofisticación con que se representa a la musmé la coloca por encima. $Y$ esa sofisticación, sin embargo, no viene acompañada del exceso ni son sus atributos los mismo que los de los salones europeos. Esas mujeres son la encarnación misma de lo minúsculo, de lo sutil, del poder de los detalles en la cultura japonesa, rasgos que a la mirada europea pasan desapercibidos: "A primera vista, todas parecen fabricadas en el mismo molde y movidas por igual resorte. Las bocas diminutas, iluminadas con un ligero toque de carmín que las hace mas pequeñas aun y más infantiles; los ojillos negros, rientes, luminosos y maliciosos; las manos finísimas, manos de princesas, y sobre todo los peinados" (Gómez Carrillo, De Marsella a Tokio. Sensaciones de Egipto, la India, la China y el Japón 146). Allí radica toda complicación y exceso, en los peinados, que pueden alcanzar hasta dieciséis estilos diferentes de los cuales —una vez más la ceguera de Occidente ante la perspicacia oriental- el cronista no puede distinguir ni uno.

Luego, cuando expresa que: "El vicio que en otros países marca a las cortesanas con su hierro candente, aquí no las ha tocado aún (...) son ingenuas" (Gómez Carrillo, El Japón heroico y galante 34), se adueña de un discurso autoritario para acuñar su construcción de un erotismo utópico, que es presentado como el único sobreviviente de la época antigua, ahora que los sables de los samuráis ya no vuelan y los príncipes no visten la moda de antaño. 
La sacralidad que el autor fabrica en torno a la sexualidad de la musmé había tenido su antecedente en la transferencia de sexualidad a la estampa de la bailarina de templos. La bayadera es una danza de seducción "la bailadora popular, la planta indígena, el fruto de la tierra. Su piel de bronce no fue nunca macerada entre esencias, y las uñas de sus pies no han sido doradas sino por el sol. Ninguna influencia sabia adultera su arte instintivo. Ningún ritual mide sus pasos" (Gómez Carrillo, De Marsella a Tokio. Sensaciones de Egipto, la India, la China y el Japón 75). Desde la representación escritural de la bailarina hindú, Carrillo venía idealizando el lugar de este grupo femenino en la sociedad. En Japón se completa la sacralización al identificarse a la bailarina con los ídolos y al ver en cada movimiento de su cuerpo un ritual que conecta, aunque pocos ojos puedan ver ya el hilo, a los mitos antiguos de los que la danza surgió en todas las culturas y que ya no puede ser apreciada en los ballets europeos, tan cargados de asuntos y preocupaciones ideológicas:

La bailarina, incansable, apenas se detiene un momento de vez en cuando. Diríase que una fuerza misteriosa la obliga á moverse, á ir, á venir, á girar, á inclinarse. (...) El poema de la coquetería sin objeto, el sagrado narcisismo de la mujer eternamente enamorada de sí propia, la música interna de los seres jóvenes, esa música que rige las ondulaciones instintivas, lo que es inconsciente armonía humana, en fin, aquí lo encuentro. Esta muchacha baila como los ídolos se inmovilizan (Gómez Carrillo, De Marsella a Tokio. Sensaciones de Egipto, la India, la China y el Japón 172). 
La contrafigura masculina de la musmé, depositaria también de la idealización gómez-carrillista, es el samurái, epicentro del honor y la galantería nipona. Por eso se horroriza el cronista de ver a un descendiente de samurái pedir una indemnización a Rusia, porque el desprecio de los bienes materiales fue uno de los rasgos primigenios del guerrero de Yamato, que creía en la sentencia: "La economía es una forma de la cobardía". Si la geisha se encontraba a gran distancia de la cortesana, el caballero nipón no lo está menos del trajeado míster de Wall Street, y no precisamente por su kimono.

Estos hombres en los que se mezclan la ciencia, la política y el arte de la guerra no se ven en Europa desde la época del Cid Campeador, de Arturo y de Roland, —si pudiéramos olvidar los botines magníficos que cargaron consigo en cada cruzada y pudiéramos fundirlos con la sapiencia de sus merlines-. Como estos héroes europeos, los samuráis tienen por atributo sus sables, forjados por igual en la leyenda y la magia. Sin embargo, aquello que fue patrimonio de unos pocos europeos es bien común de cada familia japonesa: "En cada casa, por modesta que sea, por modernizada que esté, hay un sitio en el cual una bella arma luciente (...) es objeto de veneración familiar" (Gómez Carrillo, De Marsella a Tokio. Sensaciones de Egipto, la India, la China y el Japón 223).

Carrillo conoce y nos comparte el ritual que acompaña al sable samurái, su complicado y estricto protocolo. Lo compara a las hojas alemanas y francesas, con desventajas para estas. Los considera, sin dudas, obras de arte cuya grandeza no esta en el exterior, sino en el proceso mismo de su factura y en sus atributos ocultos. Un europeo no podría distinguir, una vez más, tales 
sutilezas. Tampoco puede hacerlo Carrillo, pero la intuye en la veneración de los templos y los hombres por sus armas, en las narraciones populares que protagonizan, en el acto inteligente del coleccionista de sables que no muestra las vainas y empuñaduras a la vez que las hojas de acero, para que la mirada ignorante no vaya a lo intrascendente: "Los adornos son cosa secundaria. Lo que interesa es el acero mismo, y su temple, y su sello especial" (Gómez Carrillo, De Marsella a Tokio. Sensaciones de Egipto, la India, la China y el Japón 229).

El otro atributo de estos hombres galantes es el lenguaje, su habla diferente de la del resto, porque solo ella puede ser expresión de una cultura tan refinada, tan canonizada como la cultura samurái. "Las sílabas tienen sus reverencias y sus desdenes, sus respetos y sus altiveces, sus inclinaciones y sus muecas" (Gómez Carrillo, De Marsella a Tokio. Sensaciones de Egipto, la India, la China y el Japón 239). Ese lenguaje que casi no comprende la plebe es también -y podría decirse que, sobre todo— un lenguaje corporal. De ahí la importancia de las sonrisa y las reverencias que antes comentaba, de ahí que esa gestualidad sea la puerta que conduce al cronista a un reconocimiento del Japón que ha soñado y que, en un primer momento, no descubre en la realidad: "Esta lengua que no tiene ni insultos ni groserías, está en cambio llena de voces halagadoras y esta gente que cultiva el orgullo cual una religión conoce las más humildes maneras de prosternarse" (Gómez Carrillo, De Marsella a Tokio. Sensaciones de Egipto, la India, la China y el Japón 255). 
En el elogio de esta cultura noble y galante del samurái, sutil y encantadora de la geisha, se centra el Japón construido por la crónica de Enrique Gómez Carrillo. Los símbolos primitivistas que acompañan a esta fracción de la vida japonesa se convierten en signos de la totalidad del Japón y contribuyen así a la idealización que los escritores europeos habían venido construyendo para develar este archipiélago, extremo final de la imaginación occidental modernista.

Pero no escapa para el cronista guatemalteco que la realidad va ganando el paso a la imaginación y que el Japón que ve difiere de aquel que ha soñado. Por eso se centra en sus sensaciones de viaje, porque solo ese movimiento del alma que es la sensación puede descubrir bajo la mascarada del progreso, bajo los trajes y sombreros hongos, más allá del ring ring de los teléfonos, por encima de las cabrerías telegráficas y los modernos edificios, el alma japonesa. " iSingular y lamentable alma la del viajero! En vez de alimentarse de realidades lógicas, vive de fantasmagóricas esperanzas y sufre de inevitables desilusiones. Lo que no corresponde á su egoísmo sentimental, le causa tristezas incurables. ¡Y es tan fácil que su anhelo resulte vano!" (Gómez Carrillo, De Marsella a Tokio. Sensaciones de Egipto, la India, la China y el Japón 147-148). 
CAPITULO III DE CHILE A LA INDIA: SENDAS DEL MODERNISMO Y EL PRIMITIVISMO EN AUGUSTO D'HALMAR

Miembro de la Generación de $1900^{7}$ —como sus compañeros Joaquín Díaz Garcés, Guillermo Labarca, Carlos Pezoa Véliz, Baldomero Lillo entre otros-, Augusto G. Thomson trajo a las letras chilenas una renovación literaria asociada al realismo y al naturalismo, con toda la mirada crítica que estas corrientes habían tenido en Europa con su novela Juana Lucero (1902). Pero esa tendencia renovadora vendría acompañada de otra, más cosmopolita y deudora del movimiento literario que sacudía las letras hispánicas desde hacia casi dos décadas: el modernismo, movimiento que influiría directamente en la aparición de la vanguardia chilena. Ambas tendencias permearon su obra indistintamente, por lo que vale afirmar que Thomson (desde entonces, D'Halmar) ${ }^{8}$ se encuentra en el origen de las dos corrientes artístico-literarias que durante el siglo xx se fueron alternando y contaminando, tanto en Chile como en el resto del continente.

En los veinte años que corren desde 1880 hasta la aparición del grupo denominado "generación del 900" es posible detectar el avance de una sensibilidad diferenciada. (...) El productor cultural que se recluta en este

\footnotetext{
${ }^{7}$ La peculiaridad de la obra de este autor hace difícil encasillarlo en cualquier historia literaria. Por su inclinación naturalista en Juana Lucero y Pasión y muerte del cura Deusto (1924), algunos lo sitúan en la Generación de 1912; sin embargo, esta fue la única filiación que él mismo aceptó —ver "La Generación del 900", en Recuerdos olvidados-y la que mejor se aviene con la mayor parte de su producción literaria.

${ }^{8}$ Según Guillermo Muñoz Medina, citado por Jaime Alberto Galgani, el cambio se produjo en 1906: "Fue en una velada inaugural y, por tanto solemne. El presidente se levantó y anunció que haría uso de la palabra sobre el gran Henrik Ibsen, don Augusto Halmar, en el siglo Augusto Thomson" (Galgani, 19).
} 
medio social [las capas medias] se presenta en escena con una actitud crítica ante el opresivo predominio de la heteronomía cultural. Postula atisbos de la búsqueda de una identidad nacional que por reacción antiurbana, asocia a un modo de vida rural (Bocaz).

Ese rasgo de la formación del campo literario chileno de fines del XIX resulta inestimable para entender por qué, bajo el exquisito ropaje exótico y cosmopolita de la escritura de Augusto D'Halmar, en lo íntimo se encuentra ceñido por un primitivismo cuya raíz es el descontento con la Modernidad incompleta de América Latina. Su crítica se resuelve, no obstante, en una exaltación de valores primitivos casi nunca nacionales -al contrario de sus compañeros de generación, especialmente de Baldomero Lillo, quien bebe directamente del naturalismo—, tal vez porque el autor peregrinó durante casi tres décadas por el mundo, desconectándose del nacionalismo que impulsó la corriente criollista en la que se había iniciado con su primera novela.

Los mismos colegas de D'Halmar reconocían la diferencia al filo de su partida de Chile, en 1907, especialmente su cuñado Fernando Santiván. Por entonces las colaboraciones del autor en la prensa chilena habían pasado de la crítica artístico-literaria a la ficción, había fracasado el intento de una colonia tolstoyana —sobre la que volveré- bajo su dirección, y la influencia de Pierre Loti comenzaba a notarse en su escritura; a la par, el líder cultural va dando paso al escritor (Galgani, Augusto D'Halmar: Un proyecto cultural y literario a comienzos del siglo XX 22), lo individual se impone a lo comunal, la imaginación a la realidad; la máscara, Augusto D'Halmar, triunfa sobre Augusto Thomson. 


\section{III.1 Atisbos Primitivistas En La Obra Inicial De Augusto D'Halmar}

Sus biógrafos coinciden en que antes de La Lucero - como inicialmente se llamó la novela - Thomson había colaborado en publicaciones como Los Lunes de la Tarde e Instantáneas de Luz y Sombra con lo que sus contemporáneos llamaron 'artículos sentimentalistas', "pinceladas narrativas [que] no van encaminadas a ser cuadros ambientales, sino a expresar emociones, una vida sentimental que a veces bordea o sucumbe a lo dramático" (Concha, 41). En estas piezas narrativas se manifiesta la misma dualidad de escritor en ciernes que comentaba arriba: entre Chile y Francia, entre lo nacional y lo cosmopolita, entre el realismo y el modernismo.

En este mismo periodo formador, junto al periodista Miguel Ángel Gargari y al poeta Oscar Sepúlveda, se manifiestan intereses que luego condicionarán sus obras posteriores. Se inician en el espiritismo con experiencias que todos reflejan en sus obras, Thomson, especialmente, en su novela de 1902; dedican textos a las festividades litúrgico-sociales de Occidente, particularmente la Navidad, el Año Nuevo y el carnaval, contextos recurrentes en toda la producción del autor.

Entre los rasgos de filiación primitivista destacables en los 'artículos sentimentalistas' de estos años se encuentra la predilección por manifestaciones artísticas de corte más popular como la zarzuela frente a la opera en "Vida de cómicos", una elección que es correlato de la situación del escritor en la sociedad. Con igual signo aparece en el texto $-\mathrm{y}$ será una constante en su 
obra - el sacrificio como el modo sublimado del amor, una correlación que posee, sin dudas, una raigambre religiosa, incluso cuando muchas veces el sacrificio sea solo material. ${ }^{9}$ Este tema se encuentra emparentado también con el de la fluidez de la vida, también de raigambre mítica: algo debe morir para que algo nuevo nazca, el viejo tenor da paso al más joven en el relato.

Ambos aspectos, la opción por el arte más popular y la recurrencia del sacrificio material —presente en "Sebastopol”, "Mama Dotea”, “La vieja tía”, "Lo temido"- contienen una crítica velada a la situación de las clases media y baja en el nuevo Chile, aquel que entraba en la Modernidad: “D'Halmar nos hace tocar aquí la vergüenza más secreta de la pequeña burguesía, su llaga más sangrante. Estamos en el centro de la vida privada. Con razón se le llama así: es una vida privada... de vida" (Concha 46). A su vez, como asegura Concha, esa crítica incluye la de la situación del escritor, del artista, sacrificado socialmente por un público ingrato, ignorante.

En su primera novela — donde se dan cita todos los movimientos literarios del siglo anterior, desde la caracterización romanticoide del personaje principal hasta el lenguaje modernista, pasando por los entramados costumbrista-realistanaturalistas del contexto social— se reproduce el gusto por marcar el tiempo narrativo mediante fechas que remiten al tiempo litúrgico y nacional: el 16 de julio, día de la Virgen del Carmen, patrona del ejercito chileno, y de la muerte de

\footnotetext{
${ }^{9}$ Mientras que en estos relatos iniciales más cercanos al realismo el sacrificio posee casi siempre un carácter material, en textos como Nirvana o La sombra del humo en el espejo se habrá sublimado en la figura de los acompañantes del protagonista, siempre atentos a sus necesidades y quienes han abandonado patria y familia por seguirlo.
} 
la madre de Juana; el 20 de enero, fiesta del Roto chileno, cuando la protagonista es violada; y las infaltables navidades y fiestas de Año Nuevo. Estos hitos en el tiempo narrativo generan un compás vital de carácter cívicoreligioso, un ritmo que remite a las necesidades humanas de vencer el tiempo real por medio de la tradición, único modo, desde los inicios de la humanidad, de existir en el Tiempo.

La dilección por lo natural, propia del primitivismo de todas las épocas, posee, en un autor con miras tan cosmopolitas como Thomson, una peculiaridad: sus ambientes preferidos, aquellos en los que los personajes se sentirán más a gusto, no son el campo ni la ciudad, sino esas zonas citadinas donde la naturaleza reclama un lugar determinante, zonas intermedias, intersticios apacibles de esos mundos que a menudo son vistos como irreconciliables. Nótese en el siguiente ejemplo las evocaciones de una vida simple y tranquila que produce el barrio de Yungay:

Aquello era como estar en el campo; se sintió dichosa, rodeada por la naturaleza, adormecida por el sol ardoroso, hora de ensueños y de fantaseos, unidos el presente a los recuerdos, parecióle vivir por vez primera, desde la muerte de su madre (...) Siempre la habían seducido los paisajes campestres, la calma de las soledades donde el hombre calla y habla Dios (...) Cuando soñaba en un porvenir feliz, no lo comprendía sin todas esas cosas y jamás deseó existencias intranquilas ni ruidosas, llegando hasta dormirse en el teatro toda vez que su madre la llevara, hasta no gustar de las novelas o fantasías inverosímiles, porque amaba 
mucho más la verdad, el silencio, el retiro, que son verdades también (Thomson 86-87)

Toda la historia de esta novela se centra en el modo en el que la pretendida civilización dañó para siempre el carácter y la vida de este dulce ser apegado a la simplicidad que, inmediatamente después de este pasaje caerá en las libidinosas manos de don Absalón, un personaje que, desde la partícula que acompaña su nombre, se convierte en una representación de los grupos sociales directamente beneficiados por los procesos de modernización.

Un pasaje de marcado sesgo primitivista y romántico, donde se dan cita el individuo, la nación y la naturaleza, se ubica en la escena que marca la perdición definitiva de Juana, cuando el novio, al tanto de la violación, la desprecia:

Apoyada en un árbol, de espaldas a la cordillera cuyas nieves se apagaban en la inmensa serenidad del crepúsculo, Juana lloró silenciosamente, oyendo como algo lejano, los insultos de su amante. Arriba la victoriosa bandera azul se desplegaba, conquistaba el espacio, obligando al aurea lontananza a refugiarse tras la mancha pizarra de los cerros, y ciñendo de una larga banda esa extensión carmesí, que ya empalidecía, pero donde brillaba, cada vez con más intensidad, el diáfano solitario (Thomson 149-150)

Sobre el fondo donde se mezclan, indistinguibles los limites, el paisaje chileno y la bandera nacional, brilla el lucero solitario, la Lucero, justo antes de convertirse 
en Naná, la prostituta. ${ }^{10}$ Todos los estamentos presentes en el fragmento se encuentran sometidos a un mismo destino de soledad y decadencia, de ocaso.

Otra inclinación por lo primitivo se aprecia en las relaciones entre el mundo natural y el sobrenatural en las sesiones de espiritismo, como aquella en la que la madre consulta con sus muertos el resultado de unas gestiones para conseguir apoyo del padre de Juana en su crianza, y en las apariciones fantasmales que persiguen a la protagonista: su hijo abortado, su madre siempre en el espejo. No es mi intención realizar lecturas freudianas de estos episodios, como las que propone Jaime Concha; pero es indudable que estos pasajes apuntan a una irracionalidad ajena al naturalismo, más cercana a la búsqueda autoral de una espiritualidad nutrida posteriormente con mitos y religiones "exóticas". El mismo espiritismo participa de ese halo exótico, excéntrico, si se analiza en el marco del catolicismo oficial imperante en América Latina. Es la época del auge del espiritualismo de Alan Kardec y de la teosofía, divulgados desde Paris. Una vez más se aprecia aquí la opción por lo marginal; supersticiones, tiradoras de cartas y todo tipo de augurios conforman el tejido espiritual del mundo reflejado en la novela, en ocasiones con un tono burlesco:

Para preguntarles por qué carro deberá irse al Cementerio, Naná penetra al oráculo, donde oficia la vestal, con el suelto cabello húmedo todavía, un peine encajado entre él, y una toalla en los hombros. Justo, en ese momento, concluye de leerle a sus amigas el libro del destino, y

\footnotetext{
${ }^{10}$ Sobre otras implicaciones relacionadas con el nombre de la protagonista, el hermafroditismo y la dualidad Chile-Francia, e incluso sobre los diferentes seudónimos del autor, ver Jaime Concha, op. cit., pp. 57 y ss.
} 
recogiendo sus cuarenta hojas esparcidas sobre la cama, lo coloca enfrente de la nueva consultante, quien debe cortar tres veces con la mano siniestra (Thomson 266)

En la misma cuerda destacan los juegos cabalísticos que siempre lo acompañaron y los subterfugios semánticos con las letras del abecedario que Jaime Concha describe en su estudio, especialmente la $D$ en su definitivo seudónimo como un signo de un matrimonio consigo mismo, de una eterna soledad. Entre sus juegos con los números baste mencionar la escena del Cementerio, en la que Juana Lucero busca el nicho de su madre y se encuentra con una tumba a su nombre, una Juana Lucero muerta a sus 20 años, los mismos que tiene el autor al publicar la novela. Esa misma noche, Día de Fieles Difuntos, Juana se suicida y termina la novela.

Toda esa mezcla de religiosidad, espiritismo, supersticiones y cábalas formaban parte de la vida del autor en esos tiempos ${ }^{11}$ y se mezclaban con el conocimiento de las tradiciones mapuches que se expandía por esos años. Como muestra de ello se encuentran los machitunes, trasposición que Thomson hizo de una tradición de carácter religioso-ritual perteneciente al pueblo mapuche a una práctica de los círculos literarios chilenos de comienzos de siglo: "Eran comidas periódicas, llevadas a efecto en restaurantes de la capital, a la que asistían escritores y poetas y hombres de letra en general y donde, entre

\footnotetext{
${ }^{11}$ Jaime Concha da cuenta de la publicación de diversos artículos sobre el espiritismo en el círculo de amigos de Augusto Thomson: "En el diario La Tarde, del 5 de agosto de 1901, aparece una crónica firmada por Volney [Oscar Sepúlveda] donde se da cuenta que ha tenido lugar una reunión donde se ha evocado el espíritu del Presidente Balmaceda ("Una sesión de espiritismo")" (72).
} 
plato y libación, se hacia gala de ingenio y se daban a conocer algunas breves producciones literarias de los comensales" (Concha 70). Concha apunta, además, que la elección pudo basarse en el carácter travestido de algunos machis (conductores del culto mapuche) descritos por la literatura antropológica del momento. De cualquier modo, se trata de un intento de relacionar un ritual primitivo y un ritual moderno, del mismo modo que más adelante lo realizará Miguel A. Asturias.

Lo cierto es que los machitunes fueron un poderoso mecanismo unitario para la Generación del 900, una conjura contra la división de las letras y las artes chilenas. Alejado del espíritu individualista propio de la modernidad, Augusto Thomson y Pedro Nolasco Préndez invitaron a su mensual Asamblea de Machis a todos los artistas y literatos durante tres años. Este intento de cofradía era también la respuesta de un grupo social a la marginación que la nueva época le imponía y un espacio más de legitimación. A contrapelo del utilitarismo y el pragmatismo imperante, los "Machis" allí reunidos se reconocían y afianzaban su autoestima como individuos y como entes sociales. La invocación de la tradición araucana no pasa por alto: una vez más se trata de un índice de cómo el primitivismo cultural era parte del arsenal empleado para oponerse a los efectos nocivos de la modernización en el Continente.

Estas reuniones literarias, que el joven autor presidía como un chaman araucano, pero que — según los pocos testimonios que se han recogido, como 
un poema supuestamente escrito por Pezoa Véliz ${ }^{12}$ - mucho tenían de comelata y diversión gremial, son el antecedente de la Colonia Tolstoyana, otra experiencia artístico comunitaria que el autor compartió con Fernando Santiván y Julio Ortiz de Zarate, especialmente, entre 1904 y 1905 y que frecuentaron o admiraron muchos artistas del periodo.

Al margen de que existan dos lecturas de este momento de la vida cultural chilena - una que lo ve como una leyenda y otra, echada a rodar por las Memorias de un tolstoyano, de Santiván, que desmitifica a la colonia y a su fundador-, no cabe duda de que la Colonia Tolstoyana es también una mirada hacia lo primitivo como reacción a un descontento con el presente. En esta ocasión se trata del cristianismo incipiente, de una vuelta a la simplicidad, el pacifismo y el ascetismo de las primitivas comunidades; se trata de "la belleza de la vida sencilla, de la irresistencia al mal, del apostolado educativo que se podría ejercer entre los campesinos y de la necesidad de huir de los viciosos placeres de la vida ciudadana" (Santiván 98).

Una vez más eligen la araucanía para retirarse del mundo —la Frontera, como significativamente se le conoce- y realizar allí un verdadero proceso de ilustración, distante de aquel que había sido impuesto por Europa a América. No puede desestimarse que el modelo para el proyecto venga de otra zona excéntrica de la cultura mundial en ese momento: Rusia, y que sea hijo de los postulados de un escritor que renunció a toda su obra y su fama.

\footnotetext{
${ }^{12}$ Un fragmento del mismo puede leerse en el libro de Jaime Galgani antes citado, pp. 115-116.
} 
Malograda desde su viaje inicial, por el temor que internarse en la salvaje naturaleza americana produce en Thomson y sus amigos, la experiencia no deja de ser ilustradora de las contradicciones culturales que campeaban en el alma del autor y de sus intereses. La crónica de Santiván da cuenta de su pasión por los rituales y de su sintonía profunda con la naturaleza, muy cercana a la espiritualidad franciscana. Asegura el amigo que los criterios sobre el celibato esgrimidos por Tolstoy al final de su vida podrían haber sido otro aliciente para Thomson. Pero también refleja su apego dolorido a la civilización, lo que los lleva de soñar su Colonia en la Frontera hasta establecerla en "¡San Bernardo!..., jun arrabal de Santiago!” (Santiván 130). Baste como resumen de las aspiraciones y frustraciones de este intento de primitivismo utópico las palabras del memoralista:

Cada una de las ilusiones forjadas en un momento de entusiasmo fue deshojándose sin piedad. La vida ruda y heroica que debimos llevar en los bosques del sur, se cambió por la placida estadía en los aledaños de la capital, amparados por la sombra de parientes y amigos. Las costumbres austeras que fraternalmente debimos compartir en la casa ofrecida por Magallanes Moure, se convirtieron, poco a poco, en perpetua e insustancial academia de agudezas literarias, en estéril torneo de sutiles ocurrencias y de amables chanzas (...) Más parecíamos escolares de vacaciones que ascéticos monjes laicos. (Santiván 203)

Otros rituales cumplimentados por Augusto Thomson y que dan cuenta de su propensión a lo primitivo, su profundo contacto con lo natural y lo 
sobrenatural y su sensibilidad ajena a los avatares de la vida moderna es la despedida diaria del sol que realizaba cada tarde en el Parque Forestal de Santiago y luego en San Bernardo, de la que también da cuenta Santiván —-Se quitaba el sombrero y despedía los últimos rayos con solemnes frases y posturas de veneración pagana" (Santiván 190)—, y el recibimiento de la primavera que cada año celebraba junto a Juan Mateo Gatica en Ñuñoa.

Tal es el ambiente que antecede a la salida del autor de Chile, el escenario natural y espiritual en el que escribe su segunda novela. Aunque publicada en 1915, La lámpara en el molino es la segunda novela de Augusto Thomson, a quien ya habría que comenzar a llamar D'Halmar, pues en este texto se aprecia un giro importante hacia el estilo lírico y subjetivista que lo definiría, lejos de los coqueteos naturalistas de La Lucero. Su escritura concluyó en 1906, justo antes de la partida del autor hacia el Oriente y el escenario narrativo se inspiró en el de la vida de la Colonia en San Bernardo.

La obra muestra una transformación marcada en el programa narrativo. Desaparecen los contextos y las causas sociales como impulsores del carácter y las situaciones de los personajes; en su lugar se instala un concepto místico de la vida, como si un poder secreto condujera el destino de los hombres. Por otra parte, el lirismo, especialmente en los pasajes descriptivos, apunta de manera inequívoca al legado de Rubén Darío.

Tal vez por esa disidencia con su novela anterior o porque ya comenzaba a dominar el viento criollista en la mayor parte del continente, la novela no repercutió en el momento de su publicación —1915. Veinte años después, 
cuando la vanguardia ya era un hecho, los mismos críticos debieron corregir sus criterios y alabar el modo en el que la descripción de matices líricos estaba puesta al servicio de recrear una realidad interior y el hermetismo se convertía en la vía idónea para encadenar lo real y lo irreal en un solo motivo. Su obra se iba acercando así al imaginismo — que tomaría cuerpo definitivo en la literatura chilena hacia 1927- y, aunque no exista una relación directa entre esta corriente y el realismo mágico, no caben dudas de que la mezcla de elementos maravillosos y realistas también apunta en esa dirección.

La lámpara en el molino revela, para empezar, la profunda desconfianza de D’Halmar hacia la razón como forma de conocimiento, y hacia la voluntad como fuerza realizadora. Preconiza, en cambio, las excelencias de la fe, pero no de la fe religiosa, sino de cierta zona virgen del espíritu, donde la verdad se da en violentas llamaradas, al estilo de los presagios o las intuiciones (J. Arriagada citado por Galgani, Un proyecto cultural... 178).

Por esa razón su segunda novela refleja de un modo más acentuado el descontento de D'Halmar con el determinismo positivista y con el pragmatismo moderno. A la razón cartesiana opone el conocimiento poético, a la observación propiciada por los sentidos responde con el saber de los sueños. Todo esto evidencia que antes de su exotismo orientalista, D'Halmar ya había optado por el primitivismo, tomando de él las armas para transformar el material ajeno de sus viajes en materia poética para el conocimiento de sí y del mundo. 
La ecuanimidad de Lot, el protagonista de la novela, ante la inmovilidad del molino puede leerse precisamente en la cuerda de esa desconfianza en los valores de la moderna civilización occidental.

El punto final de la escritura de este texto es un parteaguas en la vida del autor. De aquel lado quedaban el siglo XIX, Chile, el realismo-naturalismo, los colectivismos del machitún y la Colonia Tolstoyana; de este lado se adentraba D'Halmar en lo desconocido: el nuevo siglo, el Oriente y la búsqueda de una literatura personal que ofreciera respuestas a sus descontentos: la orfandad, la homosexualidad, la poquedad del medio sociocultural, pragmático y vaciado de espíritu. De todo ello hablan los personajes de sus textos, víctimas de semejantes dilemas individuales y colectivos, casi niños, casi siempre con una representación genérica "desviada", siempre excéntricos, descalificando los valores de una modernidad que, para colmo de males, se imponía imperfecta: "sintiéndose no identificado con un sistema dominado por una racionalidad patriarcal, genera una literatura elusiva, extraña y ambigua, escéptica y desmarcada del plan programático general y común que domina el discurso decimonónico" (Galgani, Augusto D'Halmar: Un proyecto cultural y literario a comienzos del siglo XX 29).

III.2 NiRVANA Y La SOMBra Del Humo En El Espejo: Dos Miradas ComplementaRIas Al Mundo Oriental De Augusto D'Halmar

Mucho más que un libro de memorias de sus viajes por el Oriente, Nirvana (Barcelona, 1918) es un relato de viajes diversos donde los recuerdos se 
mezclan con la imaginación, y el exotismo oriental con paisajes y pasajes igualmente exóticos de la vieja Europa. El exergo, en el que el autor se ubica sobre un puente y ve pasar la corriente, como la vida, enlaza el texto con la inutilidad del molino de Lot. Espectáculo de la vida de los demás y, especialmente, de la suya propia, eso es Nirvana. No necesitará el lector de la razón, pues no es un texto para entender nada - argumento con el que D'Halmar descalifica desde el inicio la lectura positivista-, sino para sentir "deslizarse las imágenes sin rumbo (...) así, como agua que pasa” (D'Halmar, 7).

Este relato de viajes, memorias de diez años antes, se complementa con La sombra del humo en el espejo, publicada en el mismo año y de similar asunto. Aunque complementarios, ambos textos son significativamente diferentes. La sombra del humo en el espejo es menos autobiográfico, no porque no se base en la experiencia vital de su autor, sino porque posee un hilo conductor evidente: las relaciones entre el protagonista y Zahir, su amigo egipcio, papel que en Nirvana cumplen varios amigos y donde el peso se encuentra más en el espacio que en los personajes. Otra diferencia notable es la inversión del sentido del viaje, ahora de Oriente a Occidente, lo que permite acompañar a los viajeros hasta el mismo París.

Resulta significativo que el primer recuerdo evocado sea el de una "Navidad en el mar", por la recurrencia que las fechas significativas del calendario litúrgico tendrán en su obra. También por ser una fiesta donde tradicionalmente la familia se reúne, lo cual acentúa la soledad del sujeto. El otro, el pasajero que lo acompaña silencioso, es una prueba más de esa 
soledad, se convierte en el doble del autor, una figura sempiterna de ese viaje, que en ocasiones —en Nirvana- transmigra de cuerpo en cuerpo: egipcio, indio... pero siempre la misma alma.

Como si quisiera dejar constancia desde el inicio de sus temas predilectos, D'Halmar introduce, entre esa Navidad en el Atlántico y la vista de Venecia desde el Adriático, la espera del amante, los avatares del alma y el cuerpo de quien ama en secreto. Aunque no se trata de Zahir, la descripción que hace D'Halmar de estos sujetos que ama y le van amando revela su modo de asociar la naturaleza humana, la cultura y la geografía. En uno de los pasajes de tintes eróticos de La sombra del humo en el espejo, luego de insistir en el carácter andrógino de la Esfinge, asegura: "descubriendo a Zahir en la actitud hierática, comprendo no sé cómo que él es ella (...) "Era yo —me dicen, sin que se desplieguen, sus labios-, y tu no me habías reconocido. Mi alma, por unos días del tiempo, se había encarnado en un fellah para salirle al encuentro a mis amigos lejanos" (67).

Otro de sus temas recurrentes salta frente a Venecia - "No en vano el oriente comienza en la ciudad lacustre" (25)—, la reflexión sobre la muerte, cuyo origen es la abuela perdida, pero que contamina incluso el paisaje: "Y no sé si aquel pasado desvanecido, aquel silencio y aquella quietud, la inmovilidad de las lagunas estancadas y los fanales sobre pilotes carcomidos; no se si aquella fascinación de agua en la sombra (...) si las góndolas como féretros negros y los palacios blancos como sepulcros" (17). Todo aguarda la aparición de la abuela, 
y ese es el milagro, la espera que cada fragmento de la vida hace de la muerte; qué importa si al final el fantasma no aparece.

Como para cerrar el círculo de las presentaciones, mientras el buque avanza por el mar de Mármara, "en medio de la indiferencia de que nos circunda el mundo" (21), nos propone esta "Merienda de gatos", un largo pasaje dedicado íntegramente a una de las pasiones del autor: los animales, y específicamente los felinos, reales y ficticios. Ya había apuntado la estrecha relación que D'Halmar mantuvo con la naturaleza, patentada en sus reverencias al sol y a las estaciones en su natal Chile; incluso, la cercanía de su espiritualidad, en este punto, a la del pobre de Asís.

Como siempre sucede, el reconocimiento del lugar que la naturaleza tiene en la vida del hombre conduce a una reflexión sobre el orgullo de este y la peligrosa y vana barrera que ha colocado entre él y el resto del mundo natural. La naturaleza tiene sus leyes, es consecuente; pero la naturaleza humana es cambiante y conduce a una interpretación errada del prójimo y de uno mismo: "Un gato es un gato, ¿no es eso? Es decir que no podrá metamorfosearse en otra cosa (...) Un tigre también se sabe lo que es a ciencia cierta, mientras que un hombre..." (22). Su fascinación es tal que confiesa que no han sido los palacios y plazas lo que lo ha detenido en Venecia, eso "se ve todo en una tarde por una piastra" (26); han sido los gatos y el imperio que han hecho en la ciudad nocturna.

Con un estilo que en ocasiones raya en lo irónico y lúdico para revelar no solo su amor natural y sus creencias animistas; sino también su desengaño de 
los hombres y su reencuentro consigo mismo, el autor nos deja ver ya su conocimiento y práctica de las creencias orientales:

Si quisiera podría enseñar tanto con solo contar, por ejemplo, la ceremonia de mi incorporación en el Lunnat de la Frac-Gatonería veneciana; pero han cesado de interesarme los asuntos de los bípedos. Probaré algún día, que su pretendido Paraíso del Profeta, su "más allá" cristiano, su séptimo cielo de Confucio, no son sino ilusiones egoístas. Los hombres no tienen alma (o la mayoría de ellos). ¡Y cómo podría ser que les estuviese reservada una inmortalidad! La verdadera inmortalidad, o si se quiere, el nirvana, es para los gatos y para algún que otro letrado chino sin letras (28).

El pasaje es encantador no solo por los juegos de palabras con los que desviste instituciones occidentales masculinas como la masonería; resalta también el ataque realizado incluso a lo oriental intelectualizado en la figura de Confucio. No hay en D'Halmar una admiración acrítica del Oriente, un exotismo simple, sino una recuperación de los valores primigenios del ser, de aquellos que pueden conducirlo a la inmortalidad: el silencio, la simplicidad, el desapego de las cosas e, incluso, de los afectos.

Un estudio estilístico de ese capítulo de su libro resultaría suficiente para sacar a la luz la genialidad modernista del autor a la hora de torcer el lenguaje. Puestos más al servicio del humor reflexivo que de la vanidad preciosista, destellan sus "ocho días de vida a gatas" (26), su profesión de fe: "nosotros no somos gatólicos" (29) y muchos otros modos de emplear el léxico y los símbolos 
culturales asociados o cercanos, por la forma o el contenido, al mundo gatuno. El texto se complementa con una graciosa lista de proverbios protagonizados por animales —en la mayoría de los casos, por gatos- y extraídos de la supuesta Mónita Privada de la Frac-Gatonería; lista que antecede al relato de la iniciación del autor en la cofradía secreta. Solo ahora puede partir hacia el Oriente profundo, ya ha sido iniciado en sus secretos.

En Nirvana no estamos en presencia de un tradicional relato de viajes. Al contener la narración varios niveles y direcciones de trashumancia -interiores y exteriores, objetivos y subjetivos, reales, ficticios místicos...-, no es posible seguirlo en las coordenadas espacio-temporales comunes. La visita de cada territorio es también un viaje en el tiempo. "13 "Vaga y lejana vuelve..." es un acápite fechado según el calendario árabe en 1326, año de la muerte de Osmán I, la figura cumbre del Imperio Otomano. La música es aquí el hilo que une en una nueva causalidad remembranzas asociadas a la falacia de la gloria humana, que el tiempo siempre destruye. El "yo recuerdo..." se repite en cada apartado con el mismo sentido, creando un collar de cosas irrecuperables.

Del mismo modo que se encuentran unidos por el deterioro que el tiempo impone, la ruptura del mismo, el paréntesis vital que el carnaval significa en todas las culturas, es otro signo de unidad. El mundo es uno solo también cuando se le mira desde el motivo cultural de la fiesta. Como para acentuar el trastabilleo espaciotemporal he aquí la descripción del puente de Gálata, hoy

\footnotetext{
${ }^{13}$ En La sombra del humo en el espejo dirá: "como si no bastándome viajar en el espacio también necesitara hacerlo en el tiempo" (151).
} 
desaparecido: "la vida moderna y el cosmopolitismo, no se atreven a franquear el Cuerno de Oro. Y es curioso ir de uno a otro de esos dos planetas (Eski, Stambul, Yeni-Pera, lo Viejo y lo Nuevo), unidos por un simple puente y separados por una distancia no menor de quinientos años" (50). Contrastes, contradicciones de la realidad de los que se nutre la imaginación del creador, del mismo modo que décadas más tarde lo harían Carpentier y los seguidores del realismo mágico y lo real maravilloso. Y en ambas orillas, la fiesta, el carnaval.

Poco a poco, el narrador nos va develando su asimilación del mundo oriental. Entre las ganancias de esta incorporación se encuentra, por un lado, el tiempo, como ya hemos visto. La conciencia de que los recuerdos son el tiempo congelado y de que solo existe el presente - que intenta atrapar en la escritura y que termina siendo también una superficie gélida-, por lo que no vale la pena preocuparse del futuro, que no es más que el presente de Otro, aun cuando ese Otro sea uno mismo.

Esa preocupación por el tiempo y su ritualización es mucho más evidente en La sombra del humo en el espejo, tal vez porque se trata de un relato de solidez narrativa mucho más tradicional. El tiempo es aquí tiempo narrativo, ha sido sometido ya al nivel poético, por lo que el regreso a Estambul sucede exactamente un año después de la partida, y esa ritualización del tiempo se apoya en la del espacio: se hospedan en la misma casa, toma el café en el mismo puesto de antes y realiza el mismo recorrido: hacia la casa de Dina, la amada árabe. 
La justificación narrativa de esta doblegación del tiempo y el espacio es la despedida que el autor quiere hacer de esa familia y de esa amada cumpliendo, al menos a medias, la promesa de volver en un año. "Habré venido de tan lejos, a través de un cristal, barrera transparente del Destino, habré abarcado en un interior iluminado lo que pudo ser mi vida; y me alejaré como vine, solo, para no volver a volver" (170). Semejante adiós, gesto ejecutado desde una ventana, es también la aceptación definitiva de su condición sexual, pues la escena viene seguida de un ataque de celos de Zahir que el narrador nos traza con tintes líricos, como casi todo en el texto. Esta es la noche de su soledad porque sabe que no habrá para él vida de familia con hijos y sopa sobre la mesa, si acaso habrá un compañero que, como su amigo egipcio, le llame zahorí: encantador.

Por otro lado, el protagonista va conquistando el silencio, no como negación de la voz, sino como economía y concentración de los recursos comunicativos: "Y yo admiro una vez mas la discreción de palabras de estos hombres (...) Para los extranjeros, este oriente es un descanso después del asedio de todas partes y el aturdimiento, y entonces viene a comprenderse el despilfarro que hacemos en nuestra vida moderna, para envenenarla mejor y estorbarnos unos a otros" (59).

Esta es una negación del tiempo cartesiano, moderno, con sus ritmos utilitarios, en cuyos rituales — las fiestas religiosas y nacionales_ apenas queda sedimento del espíritu que los hizo nacer. Pero lo mismo sucede con el espacio. Más que una continuidad, el espacio en Nirvana es fragmentado, y el moverse incesante del viajero "hacia delante", hacia no se sabe dónde, como tantas 
veces repite, va develando un mapa íntimo: "iTierras de la tierra, maravillas dormidas en mi ensueño, que yo he ido despertando a mi paso y desencantando irremisiblemente! (...) jah! jesto que yo presentía y que he ido reconociendo como si más bien estuviese en mi ser, que en las cosas" (64).

Del mismo modo que sucede con el tiempo, muchas veces el espacio pierde sus diferencias gracias al recuerdo, como en el capitulo titulado "La Cruz del Sur", donde la contemplación del mapa estelar une la tierra y el mar que se pisan con otra tierra y otro mar, los de Chile, irrecuperables. La emblemática constelación, un signo más del poder de la naturaleza en la que confían marineros y campesinos, le hace renegar una vez más de la razón, que del mundo natural nos ha separado:

Hijos descarriados y descastados, vanamente habríamos contraído esta enfermedad del pensamiento, al separarnos de la naturaleza y ahora, como a la patria, jamás volveríamos a encontrarla; ella más inconsciente que nosotros no podía contestar nuestras complejidades soberbiamente sana la Madre Naturaleza, porque también soberbiamente bestia... Apenas si nos restaba el envidiarla (67)

Como contraste, como si al hombre no le quedara más que su razón y su hijo predilecto, el lenguaje científico, el capítulo cierra amargamente con una cita de su bitácora: " $3^{\circ} 25$ del III 190., 12 P. M. Cielo estrellado, Mar llana, noche obscura. Lat. N. 10, 41-60, 29 Long 10.41-60.29 Long. E MM. 5585. Distancia del Puerto 1215" (67). 
En varios pasajes posteriores de Nirvana la Cruz del Sur reaparecerá, en ocasiones asociada a la nostalgia por la patria perdida, que para D'Halmar nos es más que un recuerdo y, especialmente, el recuerdo de su abuela; en otros, su movimiento estelar, su ocultamiento por encima del Trópico de Cáncer propicia una acto de denuncia del sinsentido humano, de esa búsqueda infructuosa que el autor padecía y criticaba a un tiempo: "como si nos alejásemos hasta de los astros, más allá de todo, en esta carrera loca cuyo objetivo no se encuentra" (85).

La llegada a la India de sus ensueños, al destino de su misión diplomática — de la que nada se dice, nunca— viene acompañada de un sabor agridulce: el del tremendo encontronazo con la realidad. Durante años ha imaginado esta tierra, la ha diseñado en su imaginación con el hiperbólico discurso onírico; la representa una vez más así: Paraíso Terrenal, residencia de dioses diversos... Me gustaría contrastar dos miradas que el mismo autor arroja sobre la India. La primera corresponde a La sombra del humo en el espejo y es una descripción de la noche en su grandiosidad cercana a los pasajes descriptivos que antes comenté de Juana Lucero:

Poco a poco la noche que asciende, el silencio dulce y ahumado de la noche india, como una exhalación de vapores de la tierra humeante. Detrás de los boscajes y a través de las ramas, mil espejos de acero poco a poco se doran para hacerse azulados poco a poco y enfriarse en la sombra. Los senderos violáceos, con ruidos perdidos de esquilas y cantos alejados de boyeros. El clamor vesperal de los cuervos. El indescifrable 
susurro de la fronda sobre nuestras cabezas. Y más arriba, un firmamento que nos parece más elevado, donde las estrellas son más distantes e inmóviles, pero en el cual brillan aun las más pequeñas (107).

Resulta notable la idealización de esta noche sinestésica, su monumentalidad acentuada en el empleo de frases adverbiales que van de la reiteración del "poco a poco" a la repetición del "más". Y, sin embargo, ya ha comenzado el asedio de la modernidad, como en Egipto, pues en Nirvana nos deja esta otra estampa:

$\mathrm{Y}$ hoy mismo que las herraduras del foot-ball se estampan en el suelo sagrado, hoy que el ígneo sol del Asia y del África, de la India y del Egipto, rescalda los helmets, y que desgarra el monzón, no los velos de Isis y de Kali, sino los mosquiteros azules, hoy todavía reside allí el misterio oriental que tal vez sofocaremos algún día. El silbido de la locomotora, ahuyenta los elefantes y los dromedarios; pero, por todo lo alto, fuera del alcance de las Winchester, continúan revolando majestuosamente las bandas rosadas de los ibis (70).

$\mathrm{Y}$, sin embargo, el misterio permanece incólume. No pasa inadvertida la asociación entre los signos de la modernidad y el imperialismo británico, usurpador del poder de la India, tanto en los vocablos en inglés como en los mosquiteros, las locomotoras, los rifles, gramófonos y cinemas, la violencia y las victorias brutales. Esta crítica a la imposición de la modernidad y la cultura anglosajona en la tierra de sus anhelos posee un blanco más, repetido a partir de aquí en varias partes del texto: el turista. 
$Y$ he aquí que un mediodía cualquiera, en una lancha tripulada por ingleses, entre mucho sunhat y mucho velo verde, hacemos nuestra pequeña travesía hasta un muelle inglés con carteles del te Lypton y una aduana inglesa (...) y el mismo rebaño de turistas que han fotografiado las pirámides sobre el gran desierto y el Santo Sepulcro, hace registrar ahora sus Kodaks y marchan a paso de carga contra la naturaleza de este paraíso (73)

Otra vez el tono irónico, casi burlesco, en el que veo también una celebración del idioma propio; una vez más las huellas de la "civilización": esas Kodaks más omnipresentes que Dios Padre; y definitivamente la distinción: ellos son turistas, el protagonista de nuestro relato es un viajero. Ellos, ignorantes de todo, creen conocer la realidad con sus aparatos mecánicos y sus números:

Yo no podría expresar cuánto llega a odiarse (sí, a odiarse) estos snobs, menos que dilettanti, premunidos de todos los pasaportes y con cupones Cook y billetes circulares, que ni siquiera sufren el mareo y que por doquiera profanan con su borceguí de foot-ball, el sagrado polvo de los siglos. (...) toman sus cifras más atentos por cierto al dato estadístico que a la belleza misma (...) Lo consignan todo, todo lo reducen a dimensiones, fechas y sobre todo a precio en sterling (...) presumiendo también que hasta los caníbales desdeñarían sus huesos colorines, saturados de wisky, de mostaza y del mas estúpido de los orgullos que haya medrado bajo el sol (73-74). 
Su sentimiento es tan visceral que continúa aportando ejemplos de la dominante incongruencia cultural que los británicos han impuesto al Oriente: una estatua de la reina Victoria en Jerusalén, huellas en Egipto y en la India, y museos, "museos y museos que son como los cementerios de las razas, algo menos tal vez: como una especie de sala de historia natural, donde se nos mostrase envasada y en alcohol, rotulada y catalogada, la vida y la tradición" (76). Aunque nunca lo escribió, produce placer el imaginar el libro que, por inspiración de otro de Loti, proyectó escribir ante tal espectáculo: El mundo sin los ingleses... ni las inglesas, donde también asoma su misoginia.

En La sombra del humo en el espejo se repiten las diatribas contra ingleses y turistas, pero en otro escenario: El Cairo, donde el Shepeard's Hotel es un monstruo que vomita "gentes advenedizas de occidente", "ese rival enorme que arruinaba todas las pequeñas industrias privadas y monopolizaba sin competencia la actividad entera del Cairo" (22). La ciudad se nos muestra dominada por los turistas, pero en las noches, cuando todos volvían a su refugio hotelero, el narrador viaja hacia la Esfinge en el último tranvía y a sus pies yace acompañado por Zahir.

No se escapa el mundo de lo erótico, tan gustado por los bohemios de la época, de una comparación. Oriente es tan infinitamente superior que incluso en este terreno le gana la batalla a Occidente, empleando como blasón el ondularse de las bayaderas: "Nuestras estrepitosas obscenidades de oxidente, aquellos can-can, aquellos cake-walk y aquellas mattchinche, no hacen sino agitar, mientras que este ritmo se desliza como un filtro ponzoñoso, con todo el hechizo 
de la voluptuosidad" (Nirvana, 79-80). Esa X acaso es más que una indeterminación ortográfica de la época; es una burla más, una cifrada tachadura a la modernidad.

Toda la diatriba hacia Occidente contrasta con la exaltación de la naturaleza y la tradición milenaria que contempla desde el djin-rick-sha. ${ }^{14}$ Nótese como vuelven a desdibujarse las fronteras espaciotemporales en la descripción: "héte aquí las palmeras pobladas de monos y de cotorras como en el Brasil, los caminos sombreados, por donde marchan a pequeños pasos los elefantes, los búfalos y esas diminutas vacas cebús que son como animales de pesebre de Noche Buena" (75).

Y si quedaran dudas, hacia el final de La sombra del humo en el espejo, cuando salen a tomar el sol en el invierno parisino para aliviar los males de Zahir, se realiza una explícita contraposición de lo natural que, como siempre en D’Halmar, lleva adjunta una comparación cultural: “¡No! ¡Esa bola incandescente y sin fuego que, por el contrario, hacia resaltar el estremecimiento, no era el Baal Zeboub que el pobre árabe había adorado instintivamente! ¡Nosotros los occidentales no podíamos llevar la misma sangre en las venas, puesto que nuestro sol era tan distinto!" (235). Nótese que la última oración corresponde narrativamente al personaje egipcio que, desde su discurso indirecto cuestiona el mundo de su amigo.

\footnotetext{
${ }^{14}$ Por su natural gusto hacia la diferencia, D'Halmar suele emplear frases y vocablos de la lengua de esos países que visita. No obstante, eso es mucho más acentuado en este libro de 1917, y de corte menos ficcional, que en La sombra del humo en el espejo (1924), donde esta misma palabra aparece mucho más lexicalizada al ingles: rischshaws
} 
A tono con los conocimientos sobre el mundo oriental, y especialmente con su filosofía y pensamiento mítico-religioso, la despedida del mar en "Último día de navegación", después de seis meses de viaje, suscita nuevamente el cuestionamiento sobre la falacia del conocimiento humano y su afán de etiquetar, dividir, mensurar. El mar se muestra como signo de la Unidad perdida, como el último reducto de ese Todo inicial: "Sí, hemos querido aislar los simples, descomponer lo que constituía un principio único, y hasta hoy solamente el mar no ha admitido nuestros sexos incompletos, ni nuestras imaginarias fronteras" (89). Nótese cómo el animismo conduce al mito de la androginia inicial perdida, del doble que tal vez nunca sea reencontrado.

Como confirmación del modo en el que van mezclándose sus preceptos religiosos occidentales con creencias orientales pueden leerse las citas que hace de los preceptos de Manu, específicamente los relacionados con el carácter divino del hombre y su soledad ontológica: “¿Quién, pues, escucharía su plegaria? ¿A quién podría dirigirla, puesto que vosotros sois Dios?” (109).

Instalado en su nuevo trabajo burocrático, entre los cantos orientales y la compañía de su doble de turno, el joven indio Shaikh-Etbari, D'Halmar constata la falacia de otro de los grandes poderes de Occidente, la Iglesia, precisamente en un texto titulado "Domingo de Ramos en la India": "nuestra soberbia madre la Iglesia Católica, fuera de la cual no hay salvación, cobija apenas una porción ínfima de las conciencias humanas" (101). Toda la procesión le parece descolocada, ajena, y si en algo recuerda a Occidente es en la preferencia que se le da al rico en el templo, pues en esta tierra de libertades cultuales todas las 
religiones han mercadeado. Una vez más se lamenta el autor y evoca el mundo perdido de Asís, con su simplicidad y su pobreza irradiantes.

Desde los territorios árabes, como nos relata La sombra del humo en el espejo, el narrador venía comparando la fe occidental con la oriental. Primero fue la simplicidad y el misticismo casi oscuro de la capilla de san Sergio, en El Cairo, donde según la tradición la Virgen depositó al niño en su huida: “iQué lejos estamos aquí del doloroso Lourdes de los occidentales, montado como una manufactura de milagros, y qué cerca de los orígenes de nuestra religión de consuelo y de ingenuidad! (58). Luego, la aceptación de esos otros misterios, los orientales, de esas otras relaciones de los seres entre sí y con el Ser.

El fragmento que mejor revela esa asimilación en La sombra del humo en el espejo es aquel en el que nos habla de la enfermedad que lo obligó a salir de la India. ${ }^{15}$ Allí no solo se nos presenta el sufrimiento del cuerpo como un necesario paso para la metamorfosis del ser, que en su nuevo estado, "sin deseos, y, por tanto, sin ilusiones", parece "emanciparse de la rueda de las cosas" (137); también se nos revela, por boca del médico que lo atiende, una nueva explicación de la historia universal y, claro, de la individual:

Para los que profesamos la teoría del karma todo es tan sencillo. ¿Tu América, desde los dominios aztecas hasta los dominios incásicos, no fue, tal vez, según algunos arqueólogos, la cuna del Egipto? ¿Tú mismo y él, ¡quién sabe bajo qué sexos!, estáis seguros de no haber sido un par

\footnotetext{
${ }^{15}$ Una muestra más de la narratividad mayor de este libro con respect a la de Nirvana es el paralelo narrativo entre esta enfermedad de D'Halmar en la India y la que Zahir contrae desde su llegada a Europa.
} 
gemelo de hermanos o una pareja ideal de amantes, en otra existencia simultanea, Dios sabe bajo qué zodíaco? (135).

Para coronar este proceso de reconocimiento e incorporación de la otredad, el narrador y su amigo visitan uno de los escenarios más orientalizados del texto: "El Amiya. Al centro, el consultorio contra el mal de ojo, el laboratorio de manipulaciones, de un lado, y del otro, el gabinete de las experiencias de doble vista. El anciano, que se llama a sí mismo 'médico de los ópalos enturbiados y de las perlas y las turquesas anémicas', nos acoge en la sala intermedia" (144). Allí ocurre lo impensable, el narrador, que intenta ser magnetizado por el joven hijo del supuesto médico, termina hipnotizando a su hipnotizador, y es aclamado por el padre como un verdadero conocedor de esa ciencia.

Pero el proceso no estaría completo en Oriente si, además de en el alma, la metamorfosis y la asimilación no dejaran huellas en el cuerpo. D’Halmar podrá dejar, diez años después, constancia escritural de su experiencia; pero esa misma tarde la graba sobre su piel: se tatúa una media luna, signo de sus afectos, mientras Zahir se marca con la estrella de la bandera chilena. No se trata tan solo de un acto físico y real, sino de un gesto simbólico de sus elecciones personales y culturales.

A lo largo de Nirvana, el narrador también dejó constancia de su conocimiento de mitos de muchas regiones. Asimismo, en su discurso se mezclan los relatos primigenios occidentales con los orientales, confirmándonos en la idea de que el hombre es un ser mito/lógico y que, por ende, el saber que esos relatos poseen, nacido de la imaginación colectiva, es tan poderoso como 
la razón. No obstante, poco refiere D'Halmar de la cultura andina o mesoamericana — que por esos años comenzaba a revelar sus secretos a los antropólogos - y casi nunca recurre a lo araucano, como si el destierro que se ha impuesto fuera también una voraz asimilación del mundo. Esa amalgama de mitos y experiencias se manifiesta continuamente en el texto, devolviéndonos un mundo que, aunque separado por sus regiones naturales, posee una cierta unidad cultural, sobre todo, ante la muerte:

Yo me aproximé también y una última vez pude ver a Prío-Babú, envuelto en su magnífico sudario todo purificador, yerto en medio de las llamas (...) Y bajo el velo de los buitres, soñé, con la frente perlada de sudor, en la fresca sombra de los cementerios musulmanes, allá en las alturas de Eyoub o de Kassim-Pachá, y en la sombra que proyecta la Cruz sobre nuestros muertos de occidente, la paz de los campos-santos, la dulzura de recuerdo (109).

Esta imagen de la muerte, y la de la muerta, su abuela, que siempre lo acompaña y se agazapa en los rincones para realizar su aparición, marcan el final de su estancia en la India, lugar del que casi reniega como de una pesadilla. El territorio largamente soñado, su paraíso perdido, se ha convertido en "una red tendida con lianas venenosas" (111). Debe regresar a Occidente, a otros exóticos o alejados parajes, antes de reposar en París, en Madrid, en Santiago... de Chile, un país que la nostalgia comienza a citar con mayor regularidad. 
En su camarote, a bordo del regreso, los objetos que ha ido recopilando en sus viajes y que conforman una red tan enmarañada como sus experiencias y sentimientos cobran vida y dialogan entre ellos. Entre todos conforman la cosmopolita cultura del narrador, que ahora también pone en duda la legitimidad del Oriente: "Está muy moderno ese amarillo budha, como todos los amarillos después de la guerra ruso-japonesa, y su sonrisa ha sido perfectamente simiesca" (150).

No solo puede apreciarse aquí ese cosmopolitismo que constatamos de modo recurrente en D'Halmar; al darle voz a los objetos les permite rebelarse contra su poseedor, que los ha arrancado de sus tierras respectivas para llevarlos a Europa. Al darle vida les otorga la posibilidad de las imposibles mezclas, la posibilidad de la metáfora más arrebatada entre la realidad y la ficción, porque el poeta no duerme, lo asegura mientras "el escarabajo verde de los faraones acaba de entablar amistad con una araña que todos los días, a esta hora, se descuelga por su escala de seda, desde el techo" (151).

La antropomorfización de los objetos y su rebelión dejan al autor con un solo tesoro para vencer el tiempo: la escritura. Más adelante en su viaje, ya en territorio africano, otra vez la sorpresa de lo Otro le invade gratamente y los símbolos ya usados para cuestionar a la modernidad en su exotista interés por las culturas ajenas reaparecen, oponiendo a ellos el arma preferida del poeta: "Yo que no traigo de mis viajes tarjetas iluminadas, ni llevo conmigo Kodak inseparable a los turistas, ipoder fijar por medio de las palabras esta escena tan 
efímera, que se ira debilitando en mi memoria y que mañana ya no encontraré en ninguna parte (...)!" (161).

El interés por el otro lleva a D'Halmar, ya en tierras europeas, a recorrer el territorio bretón en busca de la familia de un joven marinero que conoció en el viaje de regreso y cuyo cadáver vio hundirse en las aguas del Mar Rojo: Yvon Bian. Como en los pasajes sobre la India o el territorio árabe, todos estos fragmentos asociados al mundo celta se encuentran marcados por el placer que el autor siente frente a la diferencia, la simplicidad y el tradicionalismo de las regiones excéntricas a Occidente: "yo, que amo por encima de todo a los pequeños, toda la mediocridad infantil de la suerte, el misticismo de las horas de recogimiento y el pensamiento sereno de la muerte" (La sombra del humo en el espejo 55).

Donde quiera que va, el narrador echa mano de la lengua nativa, y en Bretaña hace otro tanto, como queriendo apresar, por medio del lenguaje, una cultura. Frente a esa diferencia se pregunta hasta qué punto conviene a la limpia pared del cementerio pueblerino bretón la lápida parisina que ha traído para que la pobre familia recuerde al marinero.

Toda la vida salvaje de la Baja Bretaña, la desunión de las familias y la rapacidad campesina, pasan en este relato hecho en voz baja, casi musitante, mientras una noche tejida de fuertes brezos y agrios muérdagos, se entrelaza sobre la cabaña negruzca de granito, sobre el hogar y la madre dormida, en este último promontorio de la tierra bretona (185). 
Aquí es donde el narrador de Nirvana ha hecho un vacío, escamoteando los pasajes del regreso a Europa que sí nos ofrece La sombra del humo en el espejo. Algunos instantes de ese retorno ya han sido comentados arriba, pero desde el punto de vista narrativo es oportuno señalar que luego de atravesar el Cuerno de Oro el tiempo se acelera y vuela sobre Atenas, Roma, Florencia, Venecia, Milán y ciertos parajes de Suiza hasta llegar a París. No ofrece Occidente mucha materia narrativa — tal vez por eso no surgen estas ciudades de las páginas de Nirvana-, pero el modo en el que D'Halmar nos cuenta cómo asimila el Occidente Zahir; ese exotismo invertido, resulta para mí ilustrador.

Ante el Partenón, "para contraste de dos civilizaciones, recuerdo la exclamación ingenua de Zahir: —¡Oh, Sidi! ¿Por qué no me habías dicho que esto era casi tan grande como la Esfinge?" (183). Estaba allí ese primitivismo del pasado que es equiparable al de lo exótico, que encierra las mismas posibilidades de realización. Pero ya en Roma, Zahir comienza a enfermar, porque el pasado allí se ha modernizado demasiado y lo único meritorio de mención son las fuentes, por su abundancia y simplicidad. Un punto a parte merece Florencia, "una de las cuatro o cinco ciudades habitables de la Europa", donde D'Halmar ve una posibilidad de conciliación entre lo primitivo y lo moderno: "Florencia, que se ha modernizado sin desennoblecerse, en cuyo pasado se ha ajustado el hoy, como una piedra preciosa reciente en un engarce antiguo (...) que conciliaba, sin ser híbrida, nuestra nostalgia de tradición y nuestra fiebre de progreso" (210). 
Ese descontento con Europa, que le resulta tan inhabitable como América, es un descontento con la modernidad, con la nueva época que ha arribado y cuyos síntomas el narrador ha notado incluso en su amado mundo oriental. No hay nada que hacer, lo primigenio, lo autóctono va dejando de existir, solo puede pervivir en la escritura que, de algún modo, tal vez, lo salve. El lamento lacera las páginas finales de La sombra del humo en el espejo:

Pero a mí me cupo en triste suerte, dondequiera, de llegar momentos antes que el telón cayese sobre el deslumbrante espectáculo de siglos. ¡Oh, mi Constantinopla! ¡Oh, mi Paris! ¡Oh, el alma mía de 1909! Fuimos yo y mi chela los últimos aventuradores no aventureros (...) pues el Extremo Oriente, y el Oriente y todos los reinos occidentales que se conservaban anacrónicos habrán sido irremisiblemente desencantados en estos pocos años. Y yo, que vengo de un país de evolución incesante en una época de transición ingrata, ya no sé donde refugiar mi espíritu, habiendo inútilmente tratado de apegarme a algo intangible, a algo inviolable de acá abajo (232-233)

Parte el narrador hacia América Latina, hacia esos países de evolución incesante, a una nueva misión en el Perú, y el tema de la vejez y la muerte ocupa su escritura en Nirvana. ${ }^{16}$ La juventud, presentada como tesoro perdido, edad dorada primitiva, se ha escapado para él. Ya no hay espacio siquiera para el exotismo. El autor es biográficamente joven — tan solo han pasado dos años

\footnotetext{
${ }^{16}$ La partida de Zahir hacia Egipto desde el puerto de Marsella cierra La sombra del humo en el espejo.
} 
de su partida para Oriente, y apenas estará cinco en el Perú-, pero autobiográficamente insiste una y otra vez en la distancia que lo separa de aquellos años de la caricia maternal de la abuela y del primer amor, de aquellos años de la ilusión.

No debe descartarse el hecho de que el sujeto que narra ha surcado un complejo espacio: el real, que separa a Chile de la India, y el imaginario, que convierte esos territorios en antípodas no solo geográficas, sino culturales. La experiencia del viaje — soñado por muchos otros modernistas-, unido a la conciencia y el ejercicio de una nueva escritura, de la implantación de una nueva época que él anhela, adelanta y repudia, pueden haber alterado la comprensión de su ser en el tiempo: distante del pasado e inadaptado en su presente.

El proceso mismo de escribir sus memorias es visto por él como parte del viaje; sus memorias expresan su ser "porque a través de mi alma ha pasado la de las cosas" (La sombra del humo en el espejo 195). De este modo deja plasmado su credo poético, cargado sin temor de lo onírico y de lo subjetivo, para llegar con esas herramientas al centro de las cosas. Muy distante se encuentra este procedimiento creativo del naturalismo inicial de Juana Lucero. Esos objetos e impresiones que quedan le permiten construir el verdadero viaje, el que yace en sus recuerdos y, por ende, en sus libros. "Solo con los años he aprendido que se viaja para después, para el día en que, ya convertido en pontón, el barco recuerda sus campañas. Entonces solo son completas, en la distancia y en el tiempo" (105). 
No se trata de describir la realidad exterior, sino la experiencia interior que induce. Tal vez por eso no ve en el Perú nada exótico, casi nada digno de mención excepto la significativa huella de un pie descalzo en el portal de su casa, un pie de mujer indígena. ${ }^{17}$ La marca de esa simplicidad le hace caer en la cuenta dolorosa de que en estas tierras americanas, que doblegan los sentidos hasta la saciedad, no hay espacio para la sombra de las cosas ni para su reflejo, y de que el regreso ha significado también la perdida de esas sombras:

Yo he amado los pies hermosos y la gracia felina que comunican cuando van desnudos, a la figura esbelta. Y a tal punto, en el oriente (...) yo me había habituado a verlas marchar (...) que para volver a gustar de la coquetería parisiense, mostrando entre el fru-fru de la seda, la estrecha botina de alto empeine, con sus tacones como para un minué, tuve que volver a civilizarme... (218).

Obligado a la civilización, perdido el pasado primitivo y la tradición que se soñó; cerrada la posibilidad de una fluidez entre lo natural y lo sobrenatural, entre el individuo y la comunidad en cuyos ritos y fiestas desaparece gracias al animismo que las nutre; atrapado nuevamente en el tiempo rectilíneo de la Modernidad, siempre adelante, siempre hacia el futuro, con la nostalgia de esas causalidades tan cercanas a la casualidad... Al narrador de Nirvana solo le queda el escepticismo, la despedida y la esperanza final de que haya logrado transmitir al lector la emoción de aquellos tiempos.

${ }^{17}$ En 1917 D'Halmar había publicado un libro titulado Gatita. Costumbres del Perú, que comienza así: "De mi larga estadía en el Perú yo no conservo ningún recuerdo, como si algunas paginas hubiesen quedado en blanco en mi libro" (d'Halmar, La sombra del humo en el espejo. Gatita 255) 
Tal vez eso significa la frase final que se repite a sí mismo, "como un sonámbulo. Hoy fue ayer" (267), o el anhelo declarado unas páginas antes, que contiene su usual cuestionamiento de los nuevos tiempos:

Yo hubiese querido nacer en los buenos tiempos en que, por cada hombre en la tierra, despuntaba una estrella en el firmamento. $(\ldots)$

Pero los astrónomos, al levantar la carta de la Sion celeste, han trazado caminos y han abierto calles y ya nada yerra al venturoso azar, ni en el cosmos, ni en el microcosmos. Un meridiano regula sus horas a la eternidad, el infinito esta jalonado por grados y los elementos deben conciliar sus deberes entre el Réamur y el Fahrenheit; el cielo está sitiado por los cañones de los telescopios, y ¿cómo, pues, distraer la atención del más ínfimo asterisco, ni deducir ya un horóscopo? (233-234). 


\section{CAPÍTULO IV EL TRASPLANTE DEFINITIVO DEL PRIMITIVISMO MODERNISTA A NUESTRAS TIERRAS EN LA OBRA EN PROSA DE PEDRO PRADO}

En 1914, mientras Europa entraba en un conflicto bélico que alcanzaría proporciones mundiales, Pedro Prado y el arquitecto Julio Bertrand inauguraron, casi como una broma, Los Diez, un grupo heterogéneo de poetas, pintores, músicos y arquitectos unidos por la amistad y conducidos por Prado. Entre sus integrantes más destacados están el crítico Armando Donoso, el poeta Magallanes Moure, el pintor Juan Francisco González y el músico Alfonso Leng; ${ }^{18} \mathrm{y}$ entre sus labores literarias más importantes, la fundación de una revista y una editorial adscritas al grupo y de igual nombre.

La heterogeneidad no solo brotaba de la diversidad de manifestaciones artísticas que cultivaban sus miembros, sino de la voluntad de convertir la libertad creativa en un principio. Esto se manifestaba en las páginas de la revista Los Diez (1916-1917), cuyo discurso crítico fue variando a lo largo de sus números. La publicación destaca por otro rasgo importante para el tema que estudio: «No estamos solamente frente a textos que hacen crítica, sino que frente a textos que asumen una mira autoreflexiva y metacrítica» (Montero 42), un punto de vista que es recurrente en la obra de Prado y que, con apariciones

\footnotetext{
${ }^{18}$ La nómina incluía, además, a los escritores: Alberto Ried, Ernesto Guzmán, Augusto D’Halmar y Eduardo Barrios; los músicos Acario Cotapos y Alberto García Guerrero; y el pintor Julio Ortiz de Zárate.
} 
más o menos explícitas, utiliza como irónico mecanismo de relación con la modernidad.

Es importante abordar la obra de Prado en el contexto de esta comunidad de escritores porque en el manifiesto por ellos publicado en 1916 dan cuenta del marcado interés de este autor por lo primitivo. Sus palabras han guiado mi lectura de la obra de Prado, mucho más encabalgada entre el modernismo y la vanguardia. En dicho manifiesto, Patricio Lizama observa los aparentemente dispares mundos que a Prado interesan, desde las oníricas profundidades del ser (sueño, azar, locura) hasta «la otredad de "extraños países" y de los "innumerables caminos de la tierra"; anhela develar la vida del espacio premoderno, rural —los "campos de labranza"- y de la modernidad en sus diversas manifestaciones» (Lizama 163). Esta es la plataforma desde la cual debe realizarse cualquier análisis de su obra.

\section{IV.1 Modernismo Y Primitivismo En La Prosa De Pedro Prado}

Según los estudiosos de la literatura chilena, desde sus primeros libros de poesía Pedro Prado enrumbó la literatura de su país hacia el vanguardismo, por el uso recurrente del versolibrismo y porque:

En Flores de cardo y en El llamado del mundo, Prado entrega un universo captado en su sensorialismo, ese descubrimiento primordial del mundo no se podía someter a leyes. Ambos son un intento válido de un nuevo sistema poético que experimenta con formas novedosas; la elección de temas y motivos revela influencia modernista. Los dos 
constituyen un umbral que prepara los caminos vanguardistas de la poesía posterior (Balart Carmona y Césped Benítez, 115)

Esta cita permite contextualizar la relación entre primitivismo y modernismo en este autor, cercano al vanguardismo en determinadas actitudes irreverentes y prosaísmos. Sin embargo, no se debe pensar que la obra de Prado se encuentra más cercana de la vanguardia que del modernismo. Marina Martin, analizando la novela Alsino, destaca: "Cabe además señalar que esa fuerza innovadora presente en la escritura de Pedro Prado es, en todo caso, más afín al discurso armonioso y simbólico del modernismo que a la actitud desmitificadora de la vanguardia» (Martín 72).

Entre las rarezas de la escritura de Prado se encuentra el gusto por la prosa poética, que comenzó a cultivar en su segundo libro, La casa abandonada (1912), cuyo subtítulo resulta revelador de la actitud crítica que antes comentaba: Parábolas y pequeños ensayos.

Bajo esta forma poética, Prado conjugó su afán reflexivo con sus intereses nacionales usando imágenes y símbolos en los que aunar lo universal y lo específico. Su actitud hacia la naturaleza chilena es de aceptación gustosa, sin los exotismo de aquel criollismo que entrecomillaba las variantes regionales de la lengua. Los nombre de las plantas están en «chileno» («Los pataguas») y las estaciones del año corren al tiempo del Cono Sur. «Con todo (...) desecha ponerse un poncho araucano tanto como una clámide griega. No trata de parecer ni más chileno ni más culto de lo que naturalmente es. Piensa que lo nacional está en el escritor y no fuera de él» (Espinoza 10). 
Entre esas imágenes y símbolos que Prado suele emplear, se encuentran las de los seres desvalidos, humildes o ingenuos, seres siempre al margen, que poseen un conocimiento de otro tipo, en ocasiones superior al de los sujetos «normales». Tal es el caso de los niños en «Los juegos», «Respuesta a los niños» y «El pájaro muerto», del enfermo en «La herida», del mendigo en «Vagabundo» o del hombre de fe en «El predicador». Cuando quiere referirse a una actitud positiva ante el mundo, Prado recurre mucho a la niñez, como cuando comenta el asombro ante las cosas que debe regir el camino de los verdaderos viajeros. En ese texto, «El viajero», el motivo infantil se junta al de la crítica del exotismo:

Viajó por todos los países de la Tierra y supo que eran mayores las semejanzas internas que las diferencias exteriores que presentan los pueblos.

Supo que el placer de viajar por el mundo o de viajar por el jardín de su casa estaba relacionado con la potencia de la visión.

(...) porque es un sueño aquel concepto que los hombres tienen del espacio (Prado, La roja torre de Los Diez. Antología 30-31).

Las escenas que presentan las prosas poéticas de Prado semejan recuerdos de un viajero, no solo porque en muchas haya personajes que viajan y conocen al unísono, sino porque cada fragmento descriptivo parece una pieza del mundo y del alma del poeta, pues la vida es también un viaje. Rechazar el exotismo exteriorista y refugiarse en el universo interior contra el avance de la modernidad 
habla de un primitivismo de otro signo. El poeta, el estudiante, el niño, el viajero... ven en la naturaleza una nueva «fisonomía de las cosas» que conecta lo natural con lo humano y explica nuevas causalidades: «Bien comprendéis vosotros, oh niños insaciables!, que un guijarro no es todo lo visible de un guijarro (...) una cosa solo vale por la nueva perspectiva del mundo que ella encierra y nos ofrece» (Prado, La roja torre de Los Diez. Antología 39).

En reiteradas ocasiones la visión de un paisaje es comparado con la vida del hombre, como en el relato del improvisado cazador que sale dispuesto a conquistar la naturaleza y termina domeñado por ella, sin poder comprender el misterio de las alas que asesinaba: «Triste ante mi impotencia, vi cierta semejanza entre el pequeño bosque que bastaba para confundirme y mi propia vida» (Prado, La roja torre de Los Diez. Antología 35). En esa comparación lo telúrico triunfa, pues el hombre solo puede acercarse a ese misterio por medio de la palabra, ese «engaño», ese «viento tan débil (...) que apenas si mueve los labios» (Prado, La roja torre de Los Diez. Antología 38), o por medio de sus edificaciones, condenadas también al tiempo, envueltas en el ciclo de la vida aunque algunos no lo sepan ver («Oración del hermano arquitecto»). Este es el conocimiento que adquiere el estudiante de la parábola titulada «Fisonomía de las cosas», y no precisamente en sus libros de moral y filosofía: «Los ojos de los hombres tiñen de hombre a las cosas que observan (...) las ideas de los hombres reducen el mundo a una cosa que se parece al hombre» (Prado, La roja torre de Los Diez. Antología 32). 
Era inevitable que tales opciones creativas desembocaran en cuestionamientos a la vida moderna, cargada de utilitarismos y velocidades, como en la parábola contada en «Los caminos», donde una vez más lo natural y lo humano se juntan: «Es preciso que haya una cinta de tierra que no produzca flores ni frutos para aprovechar, con facilidad, los de la tierra restante» (Prado, La roja torre de Los Diez. Antología 36), le dice el Vecino al viñatero novicio y afanoso de lucro. "Caminos son algunos hombres que vosotros, labradores, creéis inútiles. Cuando obráis conforme a tal o cual idea (...) recorréis la senda que dejó trazada uno u otro de esos seres, que no produjeron frutos y que, sin embargo, son los caminos por donde transitan todos los frutos de la tierra» (Prado, La roja torre de Los Diez. Antología 36), dice, acto seguido, el autor.

El cultivo de este género poético-narrativo vendrá de la mano —como el subtítulo de su segundo libro anunciaba- del ensayo breve. Los motivos y temas se reiteran, pero la primacía de la reflexión sobre la narración hace que se descubran las inclinaciones primitivistas del autor en la superficie del texto.

Un importante aspecto a destacar en este sentido es el nacionalismo de Pedro Prado, manifestado en su conocimiento de la geografía y las costumbres de Chile, desde su flora, fauna y mineralogía características, hasta su artesanía, sus mitos y su peculiar variante del español, como en aquel ensayo titulado «¡Qué tanto será!», una frase popular chilena que emplea en otros textos y cuya polifuncionalidad comunicativa el autor ejemplifica magistralmente, hilvanando una cadena de preguntas y respuestas en las que la frase ocupa un lugar vital, incluso desde el punto de vista pragmático: 
—Todas tus alegrías y todos tus sufrimientos, ¿qué tanto serán?...

—Cómo! —exclamas inquieto-. ¡No habrá siquiera un premio equivalente a mi fatiga y mi dolor!

—Por grande que fuese el premio que dices, ¿qué tanto será? (Prado, La roja torre de Los Diez. Antología 149-150).

Este fragmento del diálogo nos muestra no solo la funcionalidad de la frase sino la filosofía de vida que encierra, muy cercana a la de otra que Prado comenta en el mismo trabajo, "¿Y en dei», y que nos remite a un carpe diem criollo, ${ }^{19}$ a un conocimiento concreto y ajustado de la realidad que evita preocupaciones vanas y que define, según Prado, a Chile: «Nuestro escudo nacional tiene un lema: "Por la razón o la fuerza". Este lema es fruto de una cosecha precipitada (...) ¿Por qué no buscar el lema de un pueblo en la frase que mejor compendie su espíritu? El lema de Chile debiera ser: “¿Qué tanto será!...”» (Prado, La roja torre de Los Diez. Antología 148).

Ese «chilenismo» puede apreciarse con tintes primitivistas en «Orientación de la arquitectura», uno de los ensayos que de mejor modo ejemplifica su conocimiento y amor por Chile. Allí celebra la artesanía rural, por «los tallados en madera (...) los trabajos en cuero, en plata, los dibujos de sus tejidos en lana, los bordados y encajes» (Prado, La roja torre de Los Diez. Antología 137) y la defiende de «aquellos que desprecian, de una manera tanto más torpe cuanto más inconsciente, a todo lo que, sin saber por qué, consideran

\footnotetext{
${ }^{19}$ No solo en este texto se preocupa el autor por el presente y sus significaciones ontológicas. En uno de sus ensayos más comentados expresa: «Ese instante entre dos extremos, esa luz entre el pasado y el futuro, el tiempo presente, breve como es, comprende todo lo que somos, y merced únicamente a él recordamos lo que fue e imaginamos lo que será» (Prado 131).
} 
ridículo» (Prado, La roja torre de Los Diez. Antología 137). También recuerda la arquitectura colonial, hecha a imagen y semejanza de las costumbres de antaño, y propone estudiarla sin «sentimentalismo exagerado, para dar nueva vida a algunas cosas realmente dignas, que embellecieron el aspecto y el interior de las moradas de nuestros abuelos» (Prado, La roja torre de Los Diez. Antología 138).

Tal rescate de lo primitivo chileno para el presente de la arquitectura y el interiorismo continúa con los objetos de la cultura araucana, cuyos «dibujos y sobrios coloridos de sus chamales, mantas, lamas y chaupinos, pueden originar algunas novedades decorativas» (Prado, La roja torre de Los Diez. Antología 138). El carácter estético de este primitivismo culmina con una lección de jardinería y exteriorismo para sus colegas arquitectos: «¡Cuántos beneficios traería el solo hecho de que nuestros arquitectos conocieran el valor ornamental de lo que vive y reposa en nuestros suelos!» (Prado, La roja torre de Los Diez. Antología 138).

Pero el verdadero cierre de este texto, sospecho que su intención más profunda, es el de reclamar para su época — citadina, industrial y en exceso antropocéntrica - una relación armónica con lo natural. Prado desautoriza la expresión «el hombre y la naturaleza» por considerarla fuente de «ocultas y erróneas maneras de pensar». Quien así separa solo se acerca a lo natural por medio de sus accidentes, y solo así le canta. «En tanto, ¿el hombre no es también naturaleza? Su origen, su fin, semejante al de todos, ¿no nos dice que él es solo el hermano mayor de la gran familia heterogénea, desde el hermano 
lobo, como diría San Francisco de Asís, hasta la hermana roca y la hermana estrella?» (Prado, La roja torre de Los Diez. Antología 140).

Esta defensa casi animista de una relación indisoluble entre el hombre y la naturaleza posee un correlato explícito en el ensayo: la relación entre la naturaleza y la cultura y el papel que el artista juega al revelarla. La preocupación nacionalista reaparece, pero el telurismo no viene acompañado acá de ingenuidades y poses externas. Conoce Prado que solo pueden ser «robustas y poderosas» - podría decirse, universales- las creaciones que reflejan la peculiaridad de esa relación; que solo nacen estas de los que él llama «los naturaleza-hombres» y no de «los hombres-naturaleza»: artistas pasivos, reproductores, costumbristas... Aquellos, los que coordinan, los que concentran, los que transforman, saben que «aunque en las páginas o en las obras artísticas no existan ni un nombre ni un reflejo que recuerden fácilmente a nuestro suelo o al alma colectiva, si aquello ha nacido de lo más profundo de nuestras emociones, será expresión chilena y, por añadidura, será eterna» (Prado, La roja torre de Los Diez. Antología 140).

Idénticas muestras de conocimientos, motivos y elecciones estéticas ofrece «La Ciudad de los Césares», centrado en uno de los mitos más fecundos de Suramérica. A Prado le interesan las construcciones mito-poéticas en tanto descubren «la profunda realidad de un hombre o de un pueblo», y dedica tiempo a su estudio y divulgación porque sabe que «el hombre o el pueblo que reste valor a su remota infancia y tenga en olvido sus imágenes inalcanzables y deseos insatisfechos, ignorará siempre las lejanas raíces que abrevan el sentido 
de su actual conducta incomprensible» (Prado, La roja torre de Los Diez. Antología 142).

Nótese que sus palabras destacan lo que de actuante posee un mito, su poder sobre la configuración de un carácter nacional. Esa exaltación del oro imaginario que guió la búsqueda de la Ciudad de los Césares poseyó siempre más potencia que el oro y la plata reales que iban encontrando los españoles y los chilenos en la conquista de su territorio y la creación de su cultural. Si quedaran dudas sobre el valor que le otorga a los mitos, bastan estas palabras para sanarlas:

El oro imaginario es bien otra cosa. Él sobrepasa en sentido a la cantidad, él es cualidad pura; por lo tanto, no es una fortuna dada, sino la fortuna misma. Por este motivo es capaz de proporcionar la libertad, la independencia, el disfrute, el goce y la alegría, y puede hacernos no solo generosos y benevolentes, sino propicios a obtener la salud integral, la serenidad perfecta, la verdadera sabiduría. El oro imaginario se presenta como la paz misma (Prado, La roja torre de Los Diez. Antología 143-144) No ocultan estas palabras el tono hiperbólico que suele rodear a las creaciones míticas y a los textos que se nutren de esta sabia primitiva o la reflejan. La exaltación de este mito, vivo hasta finales del siglo XVIII — cuando Lázaro Pérez, párroco de Ancud, lo persiguió por la comarca-, se complementa con el dolor por su muerte a manos de una civilización que ha «hecho imposible la existencia de la Ciudad de los Césares. Los Césares han emigrado. ¿A dónde? ¡Ya no 
queda tierra donde sustentar un sueño!» (Prado, La roja torre de Los Diez. Antología 145).

El cuestionamiento a la modernidad se repite cuando, a pesar de las fuentes europeas de esta ciudad mítica, Prado saca a relucir la bravía de la sangre indígena araucana, oponiéndola no solo a la sangre española sino «a esta época blanducha», en la que se menosprecia el valor físico y se busca inspiración en «cualquier país, no importa cuál, la cuestión es que sea extranjero y nos permita imaginar» (Prado, La roja torre de Los Diez. Antología 147). Un mito y una epopeya, un mundo primitivo que sustentan el carácter de Chile, país en el que —se lamenta el autor- «la generación a la cual pertenezco nació cuando ya hacía tiempo que la epopeya que sobrevivió al poema había terminado, y que el mito se había desvanecido para siempre. No es extraño que ahora muchos de los que me escuchen sonreían con extrañeza o desprecio» (Prado, La roja torre de Los Diez. Antología 146).

Me gustaría comentar un último texto ensayístico del autor en el que lleva estas posturas incluso al terreno político. Se trata de «Características del comunismo montañés en Chile», un trabajo motivado por el suicidio del líder socialista Luis Emilio Recabarren, en 1924. Una vez más da muestras Prado de su intensa percepción de la realidad chilena, la natural y la geopolítica, como corresponde a «un vagabundo», para quien viajar y pensar son una sola cosa. $Y$ la mención de este personaje, recurrente en sus prosas poéticas arriba comentadas, no es un exotismo de estilo, solo un vagabundo llegaría a estas comunidades olvidadas del proceso civilizatorio encarnado en el ferrocarril, ya 
que «en la velocidad creciente de los medios modernos de comunicación existe un motivo más para que el hombre de nuestros días observe cada vez menos» (Prado, La roja torre de Los Diez. Antología 153).

Aisladas, ubicadas en valles pequeños —que Prado compara, en una imagen preciosa, con coloniales patios colosales en los que se reúne la familia toda-, estas comunidades no se destacan por una cultura excelsa, pero sí por una moralidad superior. Bien se cuida Prado de reiterar que el comunismo de estos lares no se nutre de «las doctrinas comunistas de la hora presente» sino que son «el reflejo ancestral de las primeras sociedades humanas» (Prado, La roja torre de Los Diez. Antología 153). No comparte el autor las paradójicas ideas de los comunistas extranjeros: «invocan la fraternidad y tienden a desorganizar la familia» (Prado, La roja torre de Los Diez. Antología 157). El comunismo montañés busca una ampliación de esos lazos filiales «como el Poeta», dice Prado.

En este punto, sus juicios sobre Recabarren y el comunismo real se juntan con su primitivismo y su conocimiento de la realidad chilena para afirmar que el comunismo montañés «tal vez sea el camino; el camino que la humanidad extravió, y del cual se empeña en alejarse más y más» (Prado, La roja torre de Los Diez. Antología 157) —propinando un nuevo golpe a la sociedad contemporánea—; y que «Recabarren fue lejos, casi a los antípodas, a buscar la ansiada solución social. Y una parte pequeña de ella estaba escondida en su país, entre altas y olvidadas montañas» (Prado, La roja torre de Los Diez. 
Antología 158) —insistiendo en su crítica del exotismo y su afirmación nacionalista.

Un caso extremo de esta actitud crítica hacia el exotismo y sus cultores es la farsa que protagonizó junto a su amigo Antonio Castro Leal al publicar el libro Fragmentos (1921) bajo la autoría del falso autor afgano Karez I Roshan. Conformado con viejos poemas de ambos, el propósito del libro era poner en tela de juicio las modas literarias, sobre todo las referidas a la literatura exótica, y burlarse de los críticos de la época. Posee tres falsos paratextos introductorios: uno de Kahlil Gibrán, otro de Bernard Shaw y una nota de la supuesta traductora, Patricia Orth; y un cuarto: una foto del autor, jun vendedor de pollos del marcado de Santiago! Aunque pocos estudiosos de su obra le dan peso a este libro, creo con Pedro Maino que:

(...) el propósito de la parodia literaria de Prado y Castro Leal no se limita a poner fin a una moda exótica que entorpecía y sofocaba al medio literario nacional, como pudieron observar con total seguridad los críticos de la época, sino, ante todo, poner al descubierto las graves falencias que aquejaban al campo cultural. La eficacia extraordinaria de la parodia radica en el profundo conocimiento que tenían ambos escritores del funcionamiento de los procesos de consagración literaria vigentes (Maino Swinburn 6).

La opción primitivista de Pedro Prado en su prosa reflexiva, como ha podido apreciarse, se encuentra al servicio de su chilenismo. El autor recurre a lo primitivo colonial e indígena, pero también a la simpleza de lo natural en un 
concepto que engloba al hombre, muy cercano de la visión integral de la naturaleza que poseen las culturas autóctonas del continente. No hay un desprecio a lo moderno tal que conduzca a su negación y al consecuente aislamiento del artista, sino un rescate de elementos primitivos que conforman el presente de las naciones latinoamericana, no solo como historia, sino como fuerza presente.

Esa potencia que brota de las raíces latinoamericanas debe ayudar al continente a enfrentar la pérdida de la confianza en el progreso. Prado sabe que la mayoría de los latinoamericanos viven de espaldas al cambio, anclados en el positivismo y el utopismo de las repúblicas iniciales, ajenos a «los numerosos fenómenos mundiales que hablan de crisis profundas, y los más próximos que enseñan una hegemonía cultural con visos de intromisión política» (Prado, La roja torre de Los Diez. Antología 159). Ante este panorama crítico moderno y esa amenaza de colonialismo cultural el papel del intelectual cobra una relevancia mayor, su obra debe estar en absoluta consonancia con «el complejo proceso de la realidad vital» para alertar y defender lo propio. Hacia los finales de su trabajo «Ayer, hoy y mañana» Pedro Prado se pregunta: «¿Qué ocurriría en nuestro caso, empequeñecidos como están los pueblos latinoamericanos, más que por sus propias deficiencias, por su abierta admiración hacia los grandes países de la Tierra?»(Prado, La roja torre de Los Diez. Antología 160). El destino de los aztecas, los incas y de muchos pueblos del continente africano le sirven de respuesta en esta ocasión; pero Prado ya había escrito en 1914 un 
relato de ficción que responde de un modo más contundente y con mayor contemporaneidad a esta pregunta: La reina de Rapa Nui.

\section{IV.2 La Reina De Rapa nuI: La Concreción Narrativa De Una Filiación PRIMITIVISTA}

Antes de adentrarse en el estudio de esta novela resulta conveniente atisbar otros proyectos narrativos de carácter ficcional del mismo autor con el propósito de generar un marco de estudio de carácter más general. Además de su prosa poética —otros títulos serían Los Diez (1915) y Las copas (1919)— y de su prosa reflexiva, el escritor chileno escribió tres novelas La reina de Rapa Nui (1914), Alsino (1920) y Un juez rural (1924); recientemente se publicó Viaje de Antón Páez a la Ciudad de los Césares (2015), un relato escrito en 1923 y encontrado recientemente en la Universidad Católica de Chile.

Alsino, por mucho la obra más conocida de Prado, gira en torno a un personaje que reúne varias de las características preferidas por el autor y que ya comentábamos: es un niño, es campesino y, para colmo de márgenes, posee una joroba de la que nacen alas. Lleno de sueños y en flagrante enfrentamiento con su medio, Alsino quiere volar, como el poeta; quiere escapar de una realidad brutal signada por la ignorancia y el alcoholismo, hacia otros mundos: «plantea una forma de huida de una realidad hostil, masiva y aplastante en busca de las claves que expliquen el fenómeno del desencuentro del artista con su medio. Indicios de la disconformidad es la caracterización de esa otra realidad a la que 
se accede como necesaria alternativa ante la insatisfacción del presente» (Balart Carmona and Césped Benítez 118).

Este motivo del escape y la interiorización del conflicto, del vagabundo que burla norma, horarios y deberes, del viajero sin prisa, se combina con otro asunto recurrente en la obra del autor chileno: la pasión por la naturaleza y las costumbres de su país, manifestada en el empleo de un léxico plagado de chilenismos —curcuncho, huingán, queltehue...-y en descripciones del paisaje natural:

Aires tibios, densos y arremolinados peinaban y despeinaban la sementera. Tan pronto se veía de color pardo mate, al mostrar las espigas maduras; luego, brillante, al refulgir al sol en las pajas amarillas y barnizadas. En el cambio de color y en el murmullo que hacían al chocar las espigas sumisas, se podían seguir las corrientes del aire vagabundo. Ya encendían, en el apagado color de una ladera, un chispazo creciente y velos de oro vivo; ya iban, como un río de luz, en grandes y caprichosas revueltas (Prado, Alsino 43-44).

Descripciones cuya sinestesia y sensorialidad modernista se ponen al servicio de celebrar la naturaleza de la región y en las que el autor ofrece pistas sobre la narración en símbolos como el de ese «aire vagabundo» ${ }^{20}$ que despeina «las espigas sumisas». La belleza del paisaje natural se contrapone, muchas veces, a la depauperación del paisaje social, como en los finales de este mismo

\footnotetext{
${ }^{20}$ El calificativo se reitera al final del texto, cuando las cenizas de Alsino quedan «fundidas en el aire invisible y vagabundo».
} 
capítulo, cuando Alsino y el cazador de tordos «por un suburbio triste penetraron a la ciudad» antecedidos por la procesión de tordos castrados, una imagen grotesca de la masificación del individuo; o, más adelante, cuando el narrador comenta la degradación moral generalizada:

Y la verdad es que no solo el miedo, los robos y las depredaciones han aumentado. Para todos es notorio que el amor va requiriendo menos melindres y escarceos, como si todo el mundo, temiendo oír la trompeta del juicio final, tomase prisa en despedirse de la vida dejando satisfechos sus apetitos (Prado, Alsino 142).

Esos seres incultos y pobres con los que Alsino va tropezando se oponen a los que, por su poder económico, han podido incorporarse a la civilización: hacendados, comerciantes, sacerdotes... No solo encontramos en Alsino una interiorización de la novela, coincido con Balart y Césped cuando, al hacer balance de la obra, destacan que «el deseo de Prado es permanecer cerca de la naturaleza, en el seno de la vida misma, en la tierra-madre, de la cual proviene y a la cual volverá en el movimiento perdurable de la materia. Desde la perspectiva de la cosmovisión pradiana, todo esto nos habla de una peculiar forma de panteísmo espiritualizado» (Balart Carmona and Césped Benítez 122), de primitivismo.

No puede asegurarse que Alsino constituya una celebración de la fuga y la enajenación que tanto se le ha endosado al modernismo. Prado conoce el carácter periférico de la modernidad que le ha tocado, y lo denuncia, por medio del dolor de su personaje y de las injusticias sociales que en su carne, y en la de 
otros desvalidos, se muestran. El refinamiento estético y la búsqueda de un conocimiento superior del mundo, un nuevo saber poético, apuntan hacia el modernismo; pero la belleza expresiva no es su único interés, "Alsino es un genuino ejemplar de la narrativa modernista encarnando los anhelos, frustraciones y, en definitiva, la crisis espiritual de una época» (Martín 73).

Cuatro años más tarde vio la luz Un juez rural, relato en el que el autor muestra una pericia narrativa mayor, con técnicas cercanas al realismo y donde la crítica ha encontrado diversos pasajes autobiográficos. A pesar de ello no puede verse allí una novela costumbrista o perteneciente al ciclo de la novela de la tierra que despuntaba en otras zonas del Continente, pues el hecho mismo de que el personaje principal, un arquitecto, abandone su labor artística por el trabajo judicial comunitario puede leerse como un signo de la condena que la modernidad hace a valores universales como el arte y la individualidad, sometidos ahora a la ética fría del código penal.

En la novela veremos que Esteban Solaguren, su protagonista, a pesar de haber aceptado esa opción, termina revelándose contra el código positivista e intentando un imposible: juzgar a conciencia, imbricar el acto de la justicia social y el de la ética individual: «Parece, señor Intendente, que nuestras leyes se basan en el concepto de individuo, y ese concepto se me hace sospechoso: un individuo que no limita ¿qué individuo es? Su cuerpo aislado nos engaña con su apariencia independiente. ¿Sobre qué base fundar la verdadera justicia?» [112]

Un juez rural es la zona de la obra de Prado menos estudiada, tal vez por ese acercamiento al realismo que de algún modo traiciona su tono general. Los 
estudios recientes la abordan desde el derecho, como un documento probatorio del estado de cosas en el campo judicial chileno de la época. No obstante, una mirada rápida al texto devela las huellas primitivistas que busco.

Una vez más realiza Prado una opción por los humildes. El mundo de los obreros, de los suburbios abandonados, centra las descripciones de ambientes de la novela. Todo el texto sustenta sus sentidos sobre la presentación de lo roto, lo inacabado, lo imperfecto, lo consumido... Tal es la primera imagen que Solaguren tiene de su jurisdicción. En ese pasaje inicial, aunque el narrador construye el escenario desde la omnisciencia, el lector nota que se trata del recorrido y el reconocimiento de la mirada del personaje.

Él mismo, Esteban Solaguren, «gustaba de salir a vagar», como muchos de los personajes de Prado, y disfruta ante la naturaleza, contrapuesta en varios pasajes a la grotesca realidad suburbana. Esto resulta evidente al comparar los siguientes fragmentos, uno dedicado a la imbricación inefable de la belleza natural y la miseria humana; y otro, a la maravilla de la naturaleza abierta, tema de los cuadros de Solaguren y su amigo pintor:

Por todas las viviendas, en tarros viejos, ollas desportilladas y tiestos indefinibles, malvas y claveles perfumaban deliciosos. Arbolillos con los troncos mordidos por los caballos, creciendo en dolorosas contorsiones, a orillas de las aguas pútridas, ostentaban en lo alto alguna pequeña jaula de caña, donde un pajarillo invisible cantaba alegremente (91).

Aquel domingo era un día amarillento de nubes aborregadas, que dejaban filtrar una pesada y quieta resolana de oro. Toda la copa del cielo parecía 
la de un árbol, y el lento desaparecer de las nubes traía el recuerdo del silencio con que las hojas se desprenden y ruedan al olvido (101).

Precisamente desde el tema de la pintura brota el cuestionamiento más directo al mundo contemporáneo. Los ejercicios artísticos de los dos amigos son el pretexto para rebatir el realismo positivista en la representación plástica: frente al mismo modelo, el Mirador Viejo, cada uno logra una tela diferente, lo que conduce a Solaguren a escribir en su diario: «Ver resulta ser». Tales ejercicios suelen ser interrumpidos por una cotidianeidad aplastante y paupérrima, frente a la que reacciona el narrador: «¡Y fue así, por la caída de un caballo escuálido al foso de un camino, cómo, nuevamente, quedó interrumpida otra tela de Mozarena, y aquella esponjada beatitud de Solaguren volvió a contraerse hasta penetrar, otra vez reducida, a la tristeza cotidiana!» [114]

Son suficientes estos ejemplos para constatar que en Un juez rural Prado explora terrenos temáticos similares a los de sus otros textos en prosa, pero el revestimiento de los asuntos se aleja del simbolismo y ofrece de un modo más descarnado el medio social. Persisten allí las sensoriales descripciones de la naturaleza y su defensa, insiste su autor en el cuestionamiento a la civilización impuesta a América Latina desde su elección de las zonas marginales de la misma; pero los años que han pasado desde la escritura de La Reina de Rapa Nui —casi una década, con una Guerra Mundial, una revolución bolchevique y mexicana, una vanguardia artística en expansión- han hecho lo suyo, imponiendo un tono pesimista y una huella realista mejor delineada. 
No obstante, la intención de verosimilitud ya era una preocupación en Prado, pues tanto en La reina de Rapa Nui como en El viaje de Antón Páez a la Ciudad de los Césares empleó recursos narrativos para acentuarla: el relato enmarcado, el narrador testigo y, en el caso de la primera novela, múltiples elementos del trasfondo histórico, como Dutrou-Bornier, personaje referido por el director del periódico en el que labora el protagonista, que desde los inicios del texto nos ubica temporalmente hacia 1870 y cuya caracterización negativa coincide con el imaginario chileno de la época. Sin embargo, como se verá más adelante, esta novela es mucho más que la recreación imaginaria de un viaje exótico:

Si en la documentación escrita e histórica sobre Rapa Nui los puntos de vista de viajeros, marinos y científicos - acorde con las concepciones expansionistas de la época- buscan describir a los «otros» nativos desde la noción evolucionista de «salvajes» y registrar —como en un gabinete de curiosidades semióticas— sus costumbres, así como analizar las posibilidades de explotación de sus recursos, en la novela de Pedro Prado estas dimensiones adoptan una nueva tesitura. Por un lado, tanto desde las voces narrativas del europeo como de los isleños hay una suerte de reflexividad que pretende universalizar y relativizar la oposición civilización/barbarie (Montecino and Foerster 160-161).

Debe destacarse que La reina de Rapa Nui es la primera novela escrita sobre la Isla de Pascua, un texto cuyas reediciones a lo largo del siglo $x \mathrm{x}$ han sido leídas 
como un signo de los conflictos políticos-sociales internos y externos de Chile (Montecino and Foerster 162-167).

La historia marco y su manuscrito encontrado es un recurso empleado con relativa regularidad en la historia de la literatura universal, pero en Pardo alcanza tintes de superchería cuando llega incluso a comprometer la dedicatoria a Juan Francisco González, creando con él una pareja similar a la que generaría a Karez-I-Roshan, pues la autoridad del amigo pintor se alínea con la de Prado para elevar la verosimilitud de un caballero inexistente. La mayor importancia del prólogo, en el que Juan Francisco y Prado son dos personajes, se encuentra en la caracterización de este X, el personaje que nos llevará de ida y vuelta a Rapa Nui.

El narrador nos lo presenta como un ser legendario de una «edad detenida»; de estirpe cercana a la que un día poseerá Esteban Solaguren, pues había sido juez de distrito pero tuvo que dejar la tribuna por ser incapaz de llegar a la sentencia, divagando en las historias personales y las motivaciones de los acusados; con criterios feroces sobre filósofos y paradojas, un ser primitivo, para quien «un hombre de hígado era (...) el mejor de los libros» (Prado, La reina de Rapa Nui 7), directo elogio de la vida a secas.

Su otro rasgo simbólicamente especial es la carencia de nombre. Este recurso suele venir aparejado a una intención encubierta de facilitar la identificación del lector real con el personaje; en esta ocasión Prado no solo la descubre, sino que la reorienta hacia los lectores chilenos, porque de ellos es el drama que se cuenta; de paso, refuerza aun más la verosimilitud: 
Yo no he querido y no quiero dar el nombre de mi amigo, porque puede ser pariente del lector, y quizás sus aventuras y su modo de ser y de pensar le molesten. (...) Su familia estaba y está relacionada con casi todas las familias chilenas; por esto creo prudente callar. Estoy seguro que Ud. es por algún lado su pariente (Prado, La reina de Rapa Nui 5).

Si el narrador nos lo presenta en el ocaso de su vida, en medio de un relativo desorden y con esta pasión por el contacto vital, las propias palabras del manuscrito nos lo dejan ver en su juventud, ansioso de aventuras y orgulloso de Chile por poseer Rapa Nui. En el pasaje de su enfrentamiento con el director del periódico para el que trabajaba existen marcas importantes para el presente estudio. De un lado, la primera mención de la Isla, completamente bordeada del mito, lugar desconocido y mágico a donde el protagonista solo ha ido por medio de los textos escolares:

¡La Isla de Pascua! ¡Rapa Nui! Cuando estudié geografía, mi ramo predilecto, me llenaba de orgullo el párrafo aquel que dice: «Chile posee en la Oceanía la Isla de Pascua, la única colonia que puede ostentar la América del Sur». ¡La única colonia era nuestra! Encontré natural que se nos comparara a los ingleses. No se trataba, en verdad, de una gran extensión de tierra; pero, en cambio, era una tierra misteriosa. ¡Rapa Nui, resto de la antigua Lemuria! ¡Lemuria, continente fabuloso más antiguo que la famosa Atlántida y ante el cual las sencillas imaginaciones de los sabios han quedado en silencio! (Prado, La reina de Rapa Nui 11). 
Su mirada mitológica contrasta con el pragmatismo del director, para quien la isla es completamente inútil y esa es la única razón por la que Chile la posee, porque nadie la desea. Para él, un periodista solo perdería su tiempo allí, escribiendo «crudezas» sobre unos salvajes promiscuos. La oposición de criterios no es ingenua, se trata de una reconstrucción del imaginario chileno de la época sobre Rapa Nui y nos presenta dos polos asociados de un modo diverso a lo primitivo: la isla mítica y encantadora del renacimiento versus la isla inútil y agresiva para el positivismo. La novela nos muestra un viaje de redescubrimiento de Rapa Nui, un viaje que desmiente ambas posturas.

¿El viaje? Aburrido y molesto, y aunque el mar desilusiona al protagonista, Prado construye sobre él una de esas intensas descripciones de lo natural donde el sabor modernista es aún poderoso, sugestivo: «Una luz amarillenta teñía el espacio. El mar se tornaba cristalino; las olas verde y rosa eran de una trasparencia profunda; las espumas, malva y oro, hacían una música divina, y el erguido velamen, ardiente en la luz y azul en la sombra, avanzaba como una hoguera sobre el mar» (Prado, La reina de Rapa Nui 12).

El acceso a la isla es peligroso, los arrecifes de coral la defienden del desembarco. Antes de tocar tierra, el protagonista contrasta el mal carácter de Bornier, uno de los «únicos civilizados que vivían en la isla», con la buena voluntad de los nativos. La caracterización que hace de ellos se corresponde directamente con la romántica imagen del buen salvaje: generosos, ingenuos, desnudos, de cuellos largos y femeninos, de músculos elásticos y excelentes 
habilidades como nadadores. Recordemos que, por mucho que haya investigado y leído sobre Rapa Nui, Prado nunca la visitó.

Ya en tierra, el protagonista irá alcanzando, de un modo paulatino, el conocimiento de la realidad que lo circunda; pero eso solo será posible luego de aceptar que se encuentra «lejos, muy lejos» de la civilización, vaciado de sentimientos, «sin arrepentimiento ni entusiasmo», listo para conocer, verdaderamente, Rapa Nui.

Por supuesto que ese saber comienza por el elemento principal de la narración y de la cultura en la isla: su reina, Coemata Etú. En medio de un ambiente paradisiaco y de sutiles erotizaciones se nos presenta a esta «mujercita menuda y graciosa», ofreciendo sus dulces higos en medio de gallos silvestres y rodeada de una brisa naciente y curiosa bajo su túnica. Como suele suceder en la obra de Prado, el primer encuentro resulta revelador no solo de los rasgos externos, sino del conflicto en sí.

De inmediato constata el protagonista las diferencias, pues la reina no le pregunta por la salud, sino por la felicidad: «¿Estás contento? Me dijo». Acto seguido, las sutiles señales de erotización se refuerzan e, indicando la creencia animista y el símbolo modernista, la reina enreda en la mejilla del civilizado una hebra de araña. Este símbolo de la mujer-araña ha perdido en la cultura occidental su esencia primitiva, pero en la obra se encuentra muy presente, pues los habitantes de Rapa Nui creen en los poderes de la naturaleza. De este modo Prado devuelve al símbolo un gran peso proveniente de lo primitivo y lo proyecta de un modo más eficaz sobre el presente: la isla, la mujer, que pertenecían a 
Bornier, francés colonialista, comienza a inclinarse por su propio peso hacia el joven chileno.

Desde este capítulo, y a lo largo del texto, Prado empleará los nombres autóctonos con su traducción al lado, lo que demuestra el conocimiento que adquirió por medio de los libros, al igual que los topónimos a los que hace referencia en su discurso: volcanes, ciudades, islas cercanas... No sucede lo mismo con las aves y plantas, cuyos nombres en chileno plagan otros textos de Prado. Su representación de los detalles de la naturaleza se torna general allí donde el conocimiento es imperfecto, pues uno de los grandes conflictos de la isla ha sido su deforestación, incompatible con los cientos de frutos que alimentan a las mellizas cercanas a la reina y con los jardines que el protagonista encuentra a su paso. No obstante, en varias ocasiones insiste Prado en los baharú y en los toromiros, la única especie endémica de la isla que ha sobrevivido a la catástrofe natural por la que atravesó.

Otra idealización, tal vez mejor lograda, se encuentra en la recreación del discurso primitivo en parlamentos donde lo natural y lo sobrenatural se enredan para dotar el habla de mayores poderes en el intento de reflejar la realidad. Tal es el caso de la descripción que la madre de las mellizas hace de Inú, el que quiere la guerra, de la guerra misma y de la solución que su familia ha encontrado para no llamar la atención de los avariciosos: poseer lo mínimo indispensable.

Pero, como sabemos, el habla posee con el pensamiento una relación dialéctica, por lo que los parlamentos de estos personajes «primitivos» reflejan 
también un modo de pensar. Sobre la misma reina nos dice el protagonista de la historia: «Curiosa de las costumbres, que llamamos civilizadas, tenía sobre ellas juicios tan originales que me hacían admirar su inteligencia tranquila y libre» (Prado, La reina de Rapa Nui 25). Tanto importa aquí el elogio de la sapiencia «primitiva» como ese «que llamamos civilizadas», aclaración que siembra de dudas el campo semántico de lo «moderno».

Semejantes modos locutorios alcanzan la cima en la realización de profecías, como la lanzada una noche de parlamento en la playa, a la luz llena de la luna: «En Anakena, Coemata Etú, el día de hoy y el de ayer son hermanos. La luna dice que el tiempo cambiará, y yo creo que esto será pronto; porque son muy escasas las estrellas que caen en el mar» (Prado, La reina de Rapa Nui 22).

El vaticinio -que se basa en elementos precientíficos como la observación astronómica- da inicio a una escena que me interesa particularmente, pues refleja de un modo muy completo las diferencias entre civilización y barbarie que Prado desea destacar. Se trata de un juicio: Adams, el civilizado, acusa a los familiares del profeta del robo de dos ovejas negras. La reina debe mediar en estos casos y se inclina por un arreglo que se basa en el inverso absoluto de la justicia occidental:

Me has dicho, comenzó la reina con su voz armoniosa, que en tu país se castiga el robo, y yo he comprendido que se castiga porque son muchos los que, no queriendo robar, no desean que otros se apoderen de sus cosas. En Rapa Nui, en cambio, todos roban a todos; de esta manera 
nadie hace daño a nadie. ¿Por quẻ no robas tú también? (Prado, La reina de Rapa Nui 22).

El mismo rasero se aplica en la isla, según nos dicen las palabras de su reina, a la mentira: todos mienten y por eso nadie cree en la isla, pero no se miente en las noches, en el parlamento, porque cualquiera podría rebatirlo. La llaneza de los argumentos, la simplicidad y concreción de los hechos contrastan con el complicado proceso de las relaciones sociales y judiciales en Occidente. El narrador no toma partido explícito por ninguno de los sistemas, pero el hecho de que Adams, el civilizado demandante, salga sin sus ovejas y sin su sombrero indican sus preferencias.

La formula: «el día de hoy fue hermano del de ayer» cierra la escena y nos indica la continuidad del tiempo, cuyos cambios la reina se niega a aceptar a pesar de las palabras del emisario de Anakena sobre la inminencia de la sequía. La reina ha mentido en el parlamento, el protagonista alcanza por vez primera conciencia del conflicto de esa tierra, donde la luna, las estrellas, los volcanes y hasta los sapos se nos develan como una sola fuerza vital en estrecha relación con los habitantes de Rapa Nui.

Otro rasgo de lo primitivo que se manifiesta con fuerza en la novela es el asociado a lo hiperbólico y monumental, empleado acá no solo en la presentación de la naturaleza, sino en la combinación de ella con las misteriosas moles de los moai: gigantescas, enormes, soberbias, orgullosas. La presentación de las características estatuas que tanto intrigan aún al mundo viene acompañada de la leyenda sobre su creación y de los licantrópicos 
poderes de su creador: Tukuihú, héroe cultural que no solo hizo las estatuas, sino el pueblo mismo, fundador de la cultura de Rapa Nui que no murió, «en mariposa se transformó, porque amaba a los niños» (Prado, La reina de Rapa Nui 26). La leyenda de la fundación de la cultura de Rapa Nui concluye, como suele suceder, con una genealogía de reyes que vincula a Tukuihú con Coemata Etú, pasando por Gregorio, rey de fea designación porque «los extranjeros le pusieron este nombre».

Una versión más ajustada de la historia de Tukuihú escuchamos enseguida de la boca de la reina, pero no para corregir las metamorfosis ahora Tukuihú está en todas las mariposas-; sino para datar en un tiempo aun más lejano la creación de las estatuas, anteriores incluso al nacimiento del héroe cultural, es decir, divinas. La historia del punto rojo, Gregorio, en la genealogía de los reyes de Rapa Nui aparece en el capítulo siguiente, el más conocido y elogiado por la crítica: «Un veterano de la guerra de Crimea», relato intercalado en la voz de Adams que narra la historia de la colonización de la isla desde la mirada Occidental. El nombre de Gregorio le fue dado por unos misioneros cristianos que llegaron a la isla, pero era un ser débil física y espiritualmente, de lo que se aprovechó Bornier para que la muerte resolviera el reinado del lado de su hermana: Coemata Etú, con quien el habilidoso francés contraería matrimonio para gobernar la isla.

Nos encontramos en presencia de dos colonizaciones sucesivas. Primero, la conducida por los misioneros cristianos, que imponen sus reglas morales y religiosas y que sufren la oposición de la mayoría de los habitantes, liderados 
por Coemata Etú. Luego, la colonización económica de Bornier, taimada y violenta, igualmente desastrosa para el delicado sistema vital de Rapa Nui. Las semejanzas con los procesos colonizadores de América Latina son evidentes, pero lo más interesante se ubica en el terreno de los matices.

Prado logra que el discurso de Adams sea muy diferente al del protagonista, sin que pueda parecer maniquea dicha oposición, al fin y al cabo ambos son «civilizados». De su discurso se desprenden un pesimismo y un escepticismo muy creíbles, que dotan al danés de redondos rasgos como personaje. Tanto él como Bornier han venido huyendo de la justicia y en busca de riquezas fáciles a esta suerte de tierra prometida. La astucia de Bornier es comparada con la de la reina, que acepta el plan del extranjero para poder reinar, por lo que no duda en engañar a su pueblo diciéndole que Bornier y Adams eran sacerdotes de mayor alcurnia. Se sucede entonces una suerte de descolonización simbólica, un recorrido burlesco por toda la isla que antecede al establecimiento y triunfo de Bornier y sus ovejas, nótese que el humor es un recurso destacable en su discurso y el engaño una estrategia recurrente del colonizador:

Bornier se había puesto toda la ropa que pudo: una chaqueta sobre la otra, dos sombreros. Un verdadero lujo de abundancia que hizo gran impresión entre los desnudos circunstantes.

A mí, no se ría Ud., me obligó a meterme un tarro en la cabeza. Esto brillará, me decía. 
Bornier, como sumo pontífice, deshizo para comenzar, todos los matrimonios que se le presentaron, consagrados por los misioneros; formó nuevas uniones más del gusto del día de los interesados, y siguió, en lo que pudo, las tendencias de sus alegres fieles (Prado, La reina de Rapa Nui 33).

Finalmente, la huida de los misioneros y de muchos habitantes de la isla que los siguieron es la explicación que Adams ofrece para el despoblamiento de Rapa Nui, tragedia en la que el conflicto civil que los europeos desataron tuvo una responsabilidad mucho mayor que la admitida por el danés. El capítulo cierra con una carta de Bornier a los frailes en la que les reprocha «llenar de trabas y temores la vida sencilla e inocente de estos hombres buenos y primitivos» (Prado, La reina de Rapa Nui 33), por lo que les desea la condenación eterna. Adams certifica las palabras de Bornier, el protagonista agrega: «Sin embargo, amigo Adams...».

Desde el punto de vista de sus funciones narrativas, «Un veterano de la guerra de Crimea» es el capítulo que completa, con el discurso occidental —muy cercano a lo histórico- los relatos discontinuos y maravillosos del resto de los personajes sobre el pasado de la isla. Mediante él se refuerza, además, la oposición de dos mundos y dos maneras de hacer, hablar y pensar que en este territorio —el real y el ficticio— se dieron cita.

Si se desea constatar las diferencias que Prado logra en la caracterización de las voces de los personajes, basta comparar este relato intercalado con el que, en el capítulo siguiente, hace Coemata Etú para explicar 
el apego de los habitantes de Rapa Nui a su isla. Se trata de otro episodio del pasado, cuando un buque dejó en altamar a un grupo de ellos. Sin dudarlo, se lanzaron a nado de regreso:

Allá van, allá van unos tras los otros los hijos de Rapa Nui como las rondas de la careba. Las mujeres seguían a los hombres, pero el amor las había fatigado y buscaron para dormir el fondo del mar. Entonces los hombres divisaron el volcán Kau, y el volcán Kau les dio fuerzas para nadar. Y la noche llegó y siguieron en la noche nadando. Los que iban adelante no sabían de los demás. Los tiburones venían a reemplazarlos. Y el primero que nadaba vio que Rapa Nui parecía alejarse. Pero él era más fuerte que todos y no creyó en lo que veía. Y nadó sobre cada ola, y una a una las dejó vencidas y todos los tiburones lo acompañaban (Prado, La reina de Rapa Nui 34).

El carácter metafórico de sus palabras dan al pasaje tinte de leyenda, apoyado en la expresión temporal que suele acompañar a los mitos y que introduce la historia: «Mucho tiempo hace». Los elementos naturales muy caros al habitante de islas: el mar y sus olas, el tiburón adquieren propiedades antropomórficas y la muerte, una constante del pasaje, un tema tabú, solo es mencionada por medio de eufemismos: «buscaron para dormir el fondo del mar», «los tiburones venían a remplazarlos».

Acto seguido, el protagonista, contagiado ya por su estancia en la isla, le habla a Coemata Etú sobre la enormidad del espacio y el tiempo con un discurso igualmente maravilloso, para intentar convencerla de abandonar la isla. La 
aparición de los nautilos, presentados como seres mitológicos, comparados con barcos fantasmas, y el vuelo erotizado de las libélulas encarnadas cierra este fragmento de elevado sabor primitivo por la cercanía a la leyenda y las estrechas relaciones entre lo humano y lo natural que en él se revelan. Es imposible no establecer nexos entre pasajes como este y los típicos fragmentos de las obras del realismo mágico, donde se produce similar mezcla entre la realidad y la ficción, entre el lirismo y la narración, entre lo primitivo y lo moderno.

A partir de aquí la inmersión del protagonista en ese mundo tan diferente será cada vez más profunda. Su descenso al cráter del Kau, región maravillosa, último reducto de la vegetación en medio de la sequía, paraíso en la tierra, paraíso en el paraíso, viene acompañado del olvido del YO, de la suspensión de la conciencia, un atributo occidental: «Desperté sobresaltado, y la conciencia que volvía, al penetrar violentamente en mí, pareció herirme» (Prado, La reina de Rapa Nui 39). Una nueva lección recibe ahora del sabio Coturhe: en la isla la guerra era un deporte, no era la rapiña su objetivo, sino el jerarquizar y dejar claro el liderazgo, esa era la función de la fiesta más importante de la isla: Mataveri.

En este momento, la comparación entre los mundos alcanza un punto álgido, pues Prado — como ya había hecho en otros textos- emplea las estaciones tal y como se suceden en el cono Sur: Mataveri es en septiembre, en la primavera. El chileno, el occidental, asocia la primavera con el amor, pero para los rapa nui «el amor y la guerra son hermanos». Como un signo más de la decadencia de la isla, y una denuncia de los responsables, Coturhe relata la 
llegada de las enfermedades venéreas de mano de los que fueron al buque extranjero: «Rapa Nui se volvió loca de no poder amar sin caer en la muerte». Para librarse del fantasma de la enfermedad, cientos de habitantes debieron suicidarse. «Volvió así el amor y volvió triste y miedoso, porque ahora quien va a amar piensa en aquella enfermedad» (Prado, La reina de Rapa Nui 40).

El sacrificio de unos por el bien de todos, el amor como centro de la vida en la isla, la guerra como deporte y el lugar superior de la naturaleza en cada momento son las enseñanzas del sabio que terminará suicidándose, una práctica común entre los isleños, no sin antes repetir los anuncios fatídicos de la sequía. Una vez más entran en conflicto las concepciones occidentales y pascuenses: el entierro del sabio se produce entre cantos de alegría, su elección de la muerte es celebrada como un valor y no como un pecado. «Si alguien muere y no quería morir, todos le lloramos. Triste dejó la vida, ¿por qué no llorar? Coturhe Uruiri, para alegrarse la dejó, ¿por qué no alegrarnos? Oye tú las canciones y no olvides que esta noche habrá gran fiesta» (Prado, La reina de Rapa Nui 42).

Más que una fiesta, una orgía, donde se consuma el acto sexual entre Coemata Etú y el protagonista del relato, el final de una historia de amor que puede ser leída también como el proceso de interiorización de la otredad vivida por el protagonista o, en otro nivel, una imagen del paso de la isla de manos de Francia a manos de Chile. Al día siguiente, comentando con Adams los sucesos, el mismo danés reconoce que lo que parecen costumbres primitivas podrían ser el resultado «de una raza sencilla, pero trabajada por los siglos». El desastre se 
avecina, los rapa nui lo saben y prefieren elegir la muerte que recibirla de manos de la naturaleza.

Adams agrega otros relatos, intentos del autor de explicar la indescifrada escritura grabada en las piedras de la isla, otro de los tantos misterios de Rapa Nui, y de cuestionar el poder catequizador de los misioneros, pues como ha sucedido en otros casos, el cristianismo no fue más que un manto arrojado sobre otras creencias que poco a poco fueron permeándolo.

Finalmente la sequia es un hecho, el tiempo isleño, marcado por las lunas, parece detenerse en «un solo día inmóvil». De nada sirve agrandar pozos y comer raíces. Un muchacho muere por beber agua de mar. La reina enferma, delira, muere. Inmediatamente, sellando la estrecha relación entre lo humano y lo telúrico, como siguiendo la cuerda de una fluidez ontológica que fuera de Coemata Etú al cielo, comenzaron a correr sobre la isla nubes cargadas de lluvia. El poder sinestésico de la prosa modernista de Prado nos regala entonces una poderosa imagen en la que se funden la violencia del cielo y de la tierra:

«Nubes bajas y pesadas oprimían un aire fatigoso de respirar. Soplos bruscos, oleadas de viento denso e impuro caían sobre un mar de aceite. Manadas de yeguas seguidas de sus potrillos, enardecidas y temerosas, cruzaban con estruendo al gran galope, las crines agitadas, las narices abiertas y rojizas» (Prado, La reina de Rapa Nui 52).

Siguiendo una causalidad nueva, la muerte de la reina de Rapa Nui —que había pactado con Bornier, que había mentido a su pueblo en los parlamentos nocturnos, que se había entregado al chileno- permite la lluvia salvadora para 
los sobrevivientes de la catástrofe. De su túmulo, cree el protagonista ver salir blancas gaviotas. La novela y el destino de Rapa Nui se cierran. La goleta que había llevado al protagonista a la isla regresa de Tahití, sin Bornier. El protagonista parte, regresa a Chile, pero ya no es el mismo. No solo lleva una historia que contar para los cómodos lectores de El Heraldo, sino un saber nuevo que le muestra la civilización como generadora de «pueblos tristes y atormentados».

Como afirma Marisol Galilea, el exotismo inicial se ha trocado en respetuosa admiración de esa cultura. Las palabras que cierran la novela no dejan lugar a dudas sobre la causa de la tristeza y el abandono en el que Prado conoció al protagonista de la historia quien, hastiado de las costumbres civilizadas, continuaba exclamando: «Feliz la vida de tus hijos que viven lejos de la fiebre y de la ambición de los hombres nuevos. Feliz y sabia la existencia llevada entre fiestas de amor y de abundancia, y únicamente sujeta a las aguas del cielo» (Prado, La reina de Rapa Nui 55). 


\section{CONCLUSIONES}

Para los estudiosos de la historia literaria latinoamericana ha quedado claro que la literatura modernista es profundamente reflexiva de su entorno socio-histórico, y muestra de ello lo constituye el punto de vista arcaico asimilado en el cultismo lingüístico y el brillo modernista. El primitivismo modernista que estudio en estas páginas es una herramienta crítica más hacia el progresismo decimonónico.

La obra de José Martí traza el inicio de este enfrentamiento. Se erige como bastión ante la filosofía y el modo de vida de su período histórico por medio de un proyecto alternativo fundamentado en su pensamiento humanista, en el cual integra aspectos de la cultura y el modo de vida prehispánicos. Su ideología política posee una perspectiva primitivista y, del proceso de su creación, se deriva una crítica a la eficacia y la productividad capitalistas.

En su obra, el punto de vista primitivista acompaña a la tensión entre el motivo tradicional autóctono americano y la expresión esencialmente occidental, agenciando esa posición única en el amplio mosaico cultural del nuevo universalismo en el que se circunscribe el quehacer modernista. Más que un recurso retórico, su pensamiento político eleva la estética modernista y la introduce en el viejo diálogo sobre la identidad cultural americana.

En el caso de Rubén Darío, el proceso fundacional del primitivismo modernista corre por otras vías. El descontento del artista ante los paraísos arrebatados por la modernidad genera una mirada cultural fugitiva como método de resistencia por medio de la imagen poética. Esta tendencia va a predominar 
durante todo el movimiento, y es el resultado de la natural decepción del artista ante los derroteros del fin de siglo.

Su obra consolida una corriente literaria innovadora cuya herramienta fundamental es la creación de mundos artificiales. En su exotismo es posible encontrar, no siempre soterrado, un sistema de ideas subalterno donde el pensamiento mítico pre-moderno se subordina a la forma en articulado artificio. Aunque en su estética el contacto con el primitivismo es secundario en la experimentación estética, resulta decisivo en marcar direcciones que luego aflorarán en otros autores, e incluso en Darío, durante el primer cuarto del siglo $\mathrm{XX}$.

En sus textos la complicada relación entre lo europeo y lo americano evidencia la continuidad en la literatura modernista del tema del mestizaje, siempre que consideremos la condición policultural como premisa de su trabajo. Por otra parte, al tratar los nexos entre la América sajona y la América Nuestra, Darío termina optando por los atributos de esta última: la poesía, los mitos y la telúrica fuerza de su naturaleza y de su historia. En sus cuestionamientos al progreso emerge ese primitivismo fundador que antes comentaba y que, junto a sus criterios sobre la ciencia, su defensa del erotismo, sus enriquecimiento de lo religioso con diversas corrientes y su aprecio por lo mítico, lo antiguo, lo exótico, son surtidores del primitivismo modernista posterior.

Las crónicas de Gómez Carrillo sobre el Oriente insertan en la literatura y la visión Occidental del Oriente una corrección: la de la realidad experimentada por el artista en su viaje. Desde el inicio mismo de su libro De Marsella a Tokio el 
cronista cuestiona la visión de escritores comerciales centrado en la propaganda modernizadora e interesados en atraer hacia el Japón los grandes capitales, y se regocija de haber podido disfrutar aún de cientos de detalles de la primitiva cotidianeidad japonesa. El viaje mismo que nace puede ser leído como una liberación de las ataduras de la modernidad: las del conocimiento prejuiciado y las del voraz ritmo industrial.

La majestad y el telurismo de la naturaleza se va imponiendo gradualmente, pero no desde la mirada estereotipada del turista, sino desde la comprensión paulatina del viajero que más que la naturaleza ve el paisaje por medio de los ojos de los habitantes de esas tierras que le sirven de improvisados informantes. Desde allí deben leerse las críticas del cronista a la dominación inglesa, no siempre explícitas pero recurrentes, y el aferrarse en sus textos a las leyendas y a la magnifica relación entre naturaleza y cultura que presencia.

$\mathrm{Si}$ algo puede resumir el primitivismo modernista de Carrillo es la construcción y el descubrimiento de un modelo iconográfico a partir del cual se subvierten los fundamentos burgueses de la modernidad pero se mantiene la idea del progreso como positiva. Para él, la sociedad moderna ideal ha de ser progresista en un plano material, mientras que debe conservarse primitivista en arte y espíritu.

Su exotismo difiere del de otros autores por la trascendencia de la influencia parisina, convirtiéndose en un exotismo personal y directo, que cuestiona directamente la mirada de escritores europeos, a los que recurre con frecuencia para refutar o afirmar sus criterios. Los espacios íntimos, la cortesía 
nipona y sus códigos de ética, la literatura folclórica, la poesía clásica, la arquitectura tradicional, pero especialmente la musmé y su erotismo, le producen un anhelo de transformación de sus saberes y de su ser mismo.

Al igual que en Gómez Carrillo, en Augusto d'Halmar el descontento con la Modernidad y el progreso se resuelve en una exaltación de valores primitivos casi nunca nacionales. Entre los rasgos de filiación primitivista destacables en su obra temprana se encuentra la predilección por manifestaciones artísticas de corte popular y el enaltecimiento del sacrificio como modo sublimado del amor, ambos como crítica velada a la situación de las clases media y baja en el nuevo Chile, y la predilección por zonas limítrofes, tanto la que existe entre la ciudad y el campo como la que descubre entre lo natural y lo sobrenatural. Todos estos componentes forman parte del proyecto y concreción de una Colonia Tolstoyana.

A partir de su llegada a Europa, el autor comienza un recorrido hacia una literatura íntima y centrada exclusivamente en las sensaciones, excluyendo de un modo directo a la razón positivista como llave para la comprensión textual. Su literatura de viajes retoma, para profundizarlos, temas como el de la relación con la naturaleza, que lo conducen a una reflexión sobre el orgullo del hombre moderno y la peligrosa barrera que ha colocado entre él y el resto del mundo natural.

En cuanto a los elementos exóticos que aparecen en su obra, se encuentran tan interiorizados por el narrador que casi no cabe llamarlos así. No se trata de un exotismo simple sino de una recuperación de los valores 
primigenios del ser: el silencio, la simplicidad, el desapego de las cosas e, incluso, de los afectos. Esos valores saltan a la vista del autor con regularidad, como si el mundo fuera uno gracias al primitivismo que siempre pervive, y que aflora también en el motivo del carnaval, como si todo tiempo fuera un solo Tiempo: el presente.

Tal vez por eso, porque los motivos exóticos han dejado de serlo para el escritor, su cuestionamiento a los efectos devastadores de la modernización británica de la India son mucho más ácidos y directos que los de Gómez Carrillo: su burla del turista es pertinaz; su cuestionamiento de los signos "civilizatorios", visceral. En contraste, su incorporación de las ideas mítico-religiosas orientales se muestra plenamente realizada; su erotismo termina completado en el tatuaje, marca definitiva de una pertenencia a otro cuerpo, a otro tiempo y otro espacio.

En una dirección completamente diferente, pero en el mismo sentido, la obra de Pedro Prado profundiza aun más la vena primitivista del Modernismo. Lo hace, inicialmente, por el camino de su relación con la naturaleza, ahora sí, chilena, y por su galería de personajes, humildes y desvalidos, ingenuos ante la sociedad y la vida. De modo que el vagabundo, no el turista ni el viajero, es el prototipo definitivamente primitivo que encarna.

Un importante aspecto a destacar en su prosa reflexiva es el nacionalismo, manifestado en su conocimiento de la geografía y las costumbres de Chile, desde su flora, fauna y mineralogía características, hasta su artesanía, sus mitos y su peculiar variante del español. Su mirada celebra lo tradicional, 
tanto en su vertiente colonial antigua como araucana moderna. Ambas zonas de la vida humana: la natural y la cultural, son una sola en varios de sus ensayos.

Con La reina de Rapa Nui Prado da testimonio de su valía como escritor modernista que aúna al cronista, al poeta, al narrador, al ensayista, al intelectual cabal. Pero también da cuenta de un desarrollo pleno y coherente del primitivismo en la literatura modernista al incorporar esos motivos no como añadidos a la historia, sino como imprescindibles para su entendimiento.

Desde la historia marco hasta el punto final, Prado activa un arsenal literario de marcada filiación primitivista. Su visión mítica de la isla y la denuncia de los efectos de la modernización en ella; la contraposición entre habitantes nativos y recién llegados, tanto en su aspecto físico como en su moral y en sus saberes y discursos; el lugar de los mitos y las costumbres de este pueblo y sus efectos en la trama; el tema del sacrificio propiciatorio encarnado en la Reina rapa nui son elementos de este proceso creativo en el que lo que podría parecer exótico se troca en reconocimiento e incorporación de la cultura otra, tal como sucedía en los textos de D'Halmar sobre el Oriente.

Aunque manifestado en diverso grado y a variados niveles, el primitivismo, piedra de toque de la literatura latinoamericana, fue parte importante de la literatura modernista. Sus cultores bebieron de la tradición primitivista para transformarlo en un primitivismo cultural que, desde el compromiso sociopolítico martiano, pasando por las idealizaciones y desmitificaciones de Darío y Carrillo y por las incorporaciones vitales de D'Halmar, desemboca en Prado muy cerca de lo que se ha reconocido -si no lo 
es ya- como primitivismo estético de la vanguardia. Este camino fue, también, el de una ganancia: el primitivismo contribuyó, como espejo invertido, a la conquista de una conciencia del ser moderno ajustada a la realidad del intelectual latinoamericano, cuyo resultado no podía ser otro que el intento de corregir y subvertir los valores de la modernidad. 


\section{BIBLIOGRAFÍA}

Acevedo Marrero, Ramón Luis. El discurso de la ambiguedad: la narrativa modernista hispanoamericana. San Juan: Editorial Isla Negra, 2002.

Agüero San Juan, Claudio. «Las virtudes judiciales y la novela Un juez rural de Pedro Prado: apuntes para un problema ideológico.» Revista Chilena de Derecho y Ciencia Política 2.1 (2010): 29-37.

Allegra, Giovannil. «Del modernismo como antimodernidad.» Thesaurus XXXVI.1 (1981): 90-103.

Arriagada, Julio and Hugo Goldsack. Pedro Prado: un clásico de América. Concepción: Revista Atenea, 1952.

Balart Carmona, Carmen and Irma Césped Benítez. «Pedro Prado: de la ruptura al límitey del límite a la ruptura.» Revista de Literatura Hispanoamericana 34 (1997): 111-127.

Balderston, Daniel. «D'Halmar: el sagrado amor fraternal.» Taller de Letras 48 (2011): 21-28.

Bocaz, Luis. "Chile en el 1900: la emergencia del intelectual de capas medias.» 30 de May de 2003. Centro Documental Blest. 09 de January de 2016 <http://www.blest.eu/cultura/bocaz85.html>.

Bourgeois, Louis. «Augusto d'Halmar, el Loti hispanoamericano.» Hispanófila 39 (1970): 43-54.

Cáceres, Aurora. La rosa muerta. Ed. Thomas Ward. Stockcero, n.d.

Calinescu, Matei. Cinco caras de la modernidad. Modernismo, vanguardia, decadencia, kitsch, posmodernismo. Trans. María Beguirstain. Madrid: Editorial Tecnos, S. A., 1991.

Camayd-Freixas, Erik, ed. Orientalism and Identity in Latin America. Fashioning Self and Other from the (Post)Colonial Margin. The University of Arizona Press, 2013.

-. Primitivism and Identity in Latin America: Essays on Art, Literatura, and Culture. Arizona: The Arizona University Press, 2000. 
- Realismo mágico y primitivismo. Relecturas de Carpentier, Asturias, Rulfo y García Márquez. Lanham: University Press of America, 1998.

Cenzano, E Carlos. El paradigma ético de la escritura martiana: desbordes de la modernidad. Dissertation. Florida International University. Miami: FIU Electronic Theses and Dissertations, 2008.

Concha, Jaime. Leer a contraluz: Estudios de narrativa de Blest Gana a Bolaño. Santiago de Chile: Ediciones Universidad Alberto Hurtado, 2012.

Darío, Rubén. Azul. Santiago de Chile: Pequeño Dios editores, 2013.

—. El canto errante. Madrid: Mundo Latino, 1918.

—. «El caso de la señorita Amelia.» 2003. Biblioteca Virtual Universal. 18 de agosto de 2017 <http://www.biblioteca.org.ar/libros/296.pdf>.

-. Prosas profanas y otros poemas. Lima: Imprenta de Pablo E Coni e Hijos, 1986.

D'Halmar, Augusto. La sombra del humo en el espejo. Gatita. Berlin-Madrid: Editora Internacional, 1924.

—. Nirvana. Viajes al extremo Oriente. Barcelona: Casa Editorial Maucci, $1920 ?$

Díaz Rodríguez, Manuel. «Paréntesis modernista o ligero ensayo sobre el modernismo.» 2003. Biblioteca Virtual Universal. 17 de December de 2015 <http://www.biblioteca.org.ar/libros/1141.pdf>.

Espinoza, Enrique. «Pedro Prado.» Prado, Pedro. La roja torre de Los Diez. Antología. Santiago de Chile: Zig-Zag S.A., 1961. 9-24.

Galgani, Jaime Alberto. "Augusto d"Halmar en Madrid. Sus columnas en el periódico Informaciones.» Anales de Literatura Chilena 12.16 (2011): 5777.

-. Augusto D'Halmar: Un proyecto cultural y literario a comienzos del siglo XX. Santiago de Chile: Ediciones UCSH, 2008.

Galilea, Marisol. «La reina de Rapa Nui de Pedro Prado. (Una mirada desde la catástrofe).» Especulo. Revista de Estudios Literarios (2010).

Gallardo Matus, David. «Las etapas de la vida y las estaciones del ano en Alsino, de Pedro Prado.» Herencia (n.d.): 35-43. 
Gullon, Ricardo. Direcciones del Modernismo. Madrid: Alianza Editorial, 1990.

Gómez Carrillo, Enrique. Crónicas e impresiones de viajes. Guatemala: Editorial Artemis-Edinter, 1997.

-. De Marsella a Tokio. Sensaciones de Egipto, la India, la China y el Japón. París: Casa Editorial Garnier Hermanos, 1906.

—. El alma japonesa. Paris: Casa Editorial Garnier Hermanos, s/f.

—. El Japón heroico y galante. Madrid: Renacimiento, 1912.

—. La sonrisa de la Esfinge. Madrid: Casa Editorial Calleja, 1917.

Hajjaj, Karima. Oriente en la crónica de viajes: el modernismo de Enrique Gómez Carrillo (1873-1927). PhD Thesis. Universidad Complutense de Madrid. Madrid: Universidad Complutense de Madrid, n.d.

Jiménez del Campo, Paloma. «La crónica de viajes en la obra de Aurora Cáceres.» Anales de la Literatura Hispanomaericana 39 (2010): 305-315.

Jrade, Cathy. «La respuesta dariana a la hegemonía cientifica.» Crítica Hispánica 27.2 (2005): 169-186.

Levy, Kurt. "Las "alas" en Pedro Prado.» AlH Actas III. Centro Virtual Cervantes, 1968. 533-541.

Lizama, Patricio. «Manifiestos y utopías, viajes y videncia: una lectura mística de Pedro Prado.» Revista Chilena de Literatura 82 (2012): 159-177.

Lovejoy, O Arthur and George Boas. Primitivism and Related Ideas in Antiquity. London: Octagon Books, 1935.

Maino Swinburn, Pedro. «Karez-I-Roshan: una «fuente de luz» en el campo literario chileno de principios del siglo XX.» Revista Chilena de Literatura abril (2010).

Maíz, Claudio. «Las re(d)vistas latinoamericanas y las tramas culturales: Redes de difusión en el romanticismo y en el modernismo.» Cuadernos del CILHA 12.14 (2011): 73-88.

Martí Pérez, José. «El carácter de la Revista Venezolana.» Martí Pérez, José. Obras Completas. Vol. 7. La Habana: Editorial Ciencias Sociales, 1979. 26 vols. 207-212. 
Martí Pérez, José. «Los códigos nuevos.» Martí Pérez, José. Obras Completas.

Vol. 7. La Habana: Editorial Ciencias Sociales, 1979. 98-102.

Martí, José. «Amistad Funesta.» Martí, José. Obras Completas. Vol. 18. La Habana: Editorial de Ciencias Sociales, 1975.

Martí, José. «Arte aborigen.» Martí, José. Obras Completas. Vol. 08. La Habana: Editorial de Ciencias Sociales, 1975.

Martí, José. «Autores americanos aborígenes.» Martí, José. Obras Completas. Vol. 08. La Habana: Editorial de Ciencias Sciales, 1975.

Martí, José. «Carta, Nueva York septiembre 19 de 1885.» Martí, José. Obras Completas. Vol. 10. La Habana: Editorial de Ciencias Sociales, 1975.

Martí, José. «Las ruinas indias.» Martí, José. Obras Completas. Vol. 18. La Habana: Editorial de Ciencias Sociales, 1975.

Martí, José. «Nuestra América.» Martí, José. Obras Completas. Vol. 06. La Habana: Editorial de Ciencias Sociales, 1975.

—. Obras Completas. Vol. 2. La Habana: Editorial de Ciencias Sociales, 1975.

Martí, José. «Patria y libertad.» Martí, José. Obras Completas. Vol. 18. La Habana: Editorial de Ciencias Sociales, 1975.

Martín, Marina. «Alsino y la novela modernista: Pedro Prado, pintor de cadencias.» Revista Iberoamericana LXII.174 (1996): 71-84.

Martínez, Juana. «Chilenos en Madrid. Augusto D'Halmar.» Anales de Literatura Chilena 5.5 (2004): 45-60.

Montecino, Sonia and Rolf Foerster. «Feminización y etnificación: La reina de Rapa Nui de Pedro Prado.» Revista Chilena de Literatura 90 (2015): 151169.

Montenegro, Ernesto. «La sonrisa de Pedro Prado.» Revista Iberoamericana XVIII.35 (1952): 93-104.

Montero, Gonzalo. «Los Diez ante la crítica y la crítica ante Los Diez: diálogos, disputas y parodias.» Revista Los Diez (1916-1917). Santiago de Chile: Editorial Cuarto, 2011. 41-53.

Neruda, Pedro. «Mariano Latorre, Pedro Prado y mi propia sombre.» Anales de la Universidad de Chile (1971): 79-88. 
Ortiz, Renato. «América Latina: de la modernidad incompleta a la modernidad mundo.» Nueva Sociedad 166 (2000): 44-61.

Prado, Pedro. Alsino. Santiago de Chile: Casa Editorial Minerva, 1920.

-. La reina de Rapa Nui. Edición Digital. Santiago de Chile: Universidad de Chile, 1997.

—. La roja torre de Los Diez. Antología. Santiago de Chile: Zig-Zag, 1961.

Rama, Ángel. Crítica literaria y utopía en América Latina. Antioquia: Editorial Universidad de Antioquia, 2006.

—. Las máscaras democráticas del modernismo. Montevideo: Fundación Ángel Rama, 1985.

—. Rubén Darío y el modernismo. Caracas: Universidad Central de Venezuela, 1970.

Rocha Monsalve, Víctor. «El ropero torcido del extraño Augusto d'Halmar: Escritura y homoerotismo en Chile a comienzos del siglo XX.» jangada 1 (2013).

Santiván, Fernando. Memorias de un tosltoyano. Santiago de Chile: Empresa Editora Zig-Zag, 1955.

Sarlo, Beatriz. Una modernidad periférica: Buenos Aires 1920-1930. Buenos Aires: Nueva Visión, 1988.

Schulman, Iván A. El proyecto inconcluso: la vigencia del Modernismo. México/Buenos Aires: Siglo XXI editores, 2002.

Sculman, Ivan. Símbolo y color en la obra de José Martí. Madrid: Gredos, 1960.

Thomson, Augusto. Juana Lucero. Los vicios de Chile. Santiago de Chile: Imprenta, Litografía y Encuadernación Turín, 1902.

Tinajero, Araceli. Orientalismo en el Modernismo hispanoamericano. West Lafayette: Purdue University, 2004.

Villanueva-Collado, Alfredo. «El puer virginal y el doble: Configuraciones arquetípicas en Pasión y muerte del cura Deusto, por Augusto d'Halmar.» Chasqui 25.1 (1996): 3-11.

Ward, Thomas. «El pensamiento religioso de Rubén Darío: un estudio de Prosas Profanas y Cantos de vida y esperanza.» Revista Iberoamericana 59 (1989): 363-375. 


\section{VITA}

SARA M. GONZALEZ

\section{EDUCATION AND EXPERIENCE}

Ph. D, 2018

Adjunct, 2018
Latin American Studies, Literature \& Culture Florida International University, Miami, FL Dissertation Title: "Primitivismo y modernidad en la literatura modernista Hispanoamericana" Committee Members: Erik Camayd-Freixas (Chair), Maida Watson, Renee Silverman, and Sherry Johnson

Spanish Language, Culture and Literature Courses

Barry University, Miami, FL

Teach undergraduate courses of elementary, intermediate and advanced Spanish.

Responsibilities include teaching Spanish language, culture and literature, facilitating communication between the students using a task-based approach, providing guidance and feedback to students inside and outside of the classroom, evaluating students' progress through oral evaluations, written assignments, and group presentations.

Teaching Assistant, 2008-2014 Spanish Language and Literature Courses Florida International University, Miami, FL Taught undergraduate courses of Spanish at the beginner, Intermediate, and advanced level.

M.A, 2008 Latin American \& Iberian Studies Auburn University, Auburn, AL

Teaching Assistant, 2006-2008 Spanish Language Courses Auburn University, Auburn, AL Taught undergraduate courses of Spanish at the beginner level.

B.A, 2003

Biological Sciences

Florida International University, Miami, FL 
RESEARCH INTERESTS

Nineteenth century Spanish American literature Second language acquisition

Task-based teaching methodology

Cultural studies in Latin America and the Caribbean Golden Age Mexican cinema

COURSES TAUGHT

Spanish American Literature Intermediate Spanish for Native Speakers Intermediate Spanish II

Intermediate Spanish I

Elementary Spanish II

Elementary Spanish I, taught fully online Elementary Spanish I

GRANTS AND FELLOWSHIPS

Funded

Gonzalez, Sara. (2013). Dissertation Evidence Acquisition

Fellowship, Florida International University Graduate School.

$\$ 8,000$.

Gonzalez, Sara. (2012). Pablo Ruiz-Orozco and Miguel Angel Quesada Memorial Scholarship. \$1,000.

MEMBERSHIPS

Modern Language Association (MLA)

Sigma Delta Pi (Hispanic Honor Society) (Omega Zeta)

\section{LANGUAGES}

Spanish (native)

English (near native)

Italian (reading and listening, able to work with primary sources)

PRESENTATIONS AND PUBLICATIONS

Gonzalez, Sara. Julián del Casal: Iluminando La Habana. Reading Cuba: An Interdisciplinary Conference on Cuban an Cuban-American Literature. Florida International University, Miami, FL. November 9-19, 2016

Gonzalez, Sara. Reinscripcion del mito de la casa fantasma en Casa de juegos de Daina Chaviano. Third International Conference on Caribbean Studies. Marquette University, Milwaukee, WI, April 11-13, 2013.

Gonzalez, Sara. Entre el realismo y lo mágico en Jardín, de Dulce María Loynaz. Alabama Modern Languages Conference: Transatlantic Topics in Language and Literatura. University of Alabama, Tuscaloosa, AL, November 18-20, 2010. 
Gonzalez, Sara. Nuestra América en Lucía Jerez, de José Martí. Second International Conference on Caribbean Studies: Looking to the Caribbean: Film and Literature. Marquette University. Milwaukee, WI. October 7-9, 2010.

Gonzalez, Sara. Tropos de poder: Construcción de un discurso desestabilizador en la poética de Juana Borrero. V Interdisciplinary Colloquium on Spanish and Latin American Literatures, Linguistics, and Cultures. University of Florida. Gainesville, FL. February, 2010.

Gonzalez, Sara. "Tropos de poder: Construcción de un discurso desestabilizador en la poética de Juana Borrero." El Cid, 2015. 